Contract No. W-7405-eng-26

ORNL NUCLEAR SAFETY RESEARCH AND DEVELOPMENT PROGRAM BIMONTHLY REPORT FOR MARCH-APRIL 1971

Wm. B. Cottre11

This report was prepared as an account of work sponsored by the United States Government. Neither the United States nor the United States Atomic Energy Commission, nor any of their employees, nor any of their contractors, subcontractors, or their employees, makes any warranty, express or implied, or assumes any legal liability or responsibility for the accuracy, completeness or usefulness of any information, apparatus, product or process disclosed, or represents that its use would not infringe privately owned rights.

\title{
JULY 1971
}

\author{
OAK RIDGE NATIONAL LABORATORY \\ Oak Ridge, Tennessee \\ operated by \\ UNION CARBIDE CORPORATION \\ for the
}

U.S. ATOMIC ENERGY COMMISSION 
$\bullet$ 


\section{DISCLAIMER}

This report was prepared as an account of work sponsored by an agency of the United States Government. Neither the United States Government nor any agency Thereof, nor any of their employees, makes any warranty, express or implied, or assumes any legal liability or responsibility for the accuracy, completeness, or usefulness of any information, apparatus, product, or process disclosed, or represents that its use would not infringe privately owned rights. Reference herein to any specific commercial product, process, or service by trade name, trademark, manufacturer, or otherwise does not necessarily constitute or imply its endorsement, recommendation, or favoring by the United States Government or any agency thereof. The views and opinions of authors expressed herein do not necessarily state or reflect those of the United States Government or any agency thereof. 


\section{DISCLAIMER}

Portions of this document may be illegible in electronic image products. Images are produced from the best available original document. 
LIST OF PREVIOUS REPORTS IN THIS SERIES

1. FAILURE MODES OF ZIRCALOY-CLAD FUEL RODS $\ldots \ldots \ldots \ldots \ldots \ldots \ldots \ldots \ldots$

1.1 Program Objectives and Coordination ....... 046001101

1.2 High-Temperature Properties and Meta1lurgical Evaluation of Zircaloy Clad-

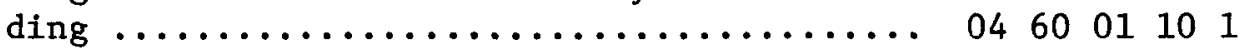

1.3 Cladding Behavior in Loss-of-Coolant

Accident Environment .................. 046001101

1.4 Transient Tests of Zircaloy-Clad Fuel

Rod Clusters in TREAT ................ 046001101

1.5 Rupture Tests of Irradiated Fuel Rods ..... 046001101

2. LMFBR SAFETY STUDIES $\ldots \ldots \ldots \ldots \ldots \ldots \ldots \ldots \ldots \ldots \ldots \ldots \ldots \ldots \ldots \ldots$

2.1 FFM Program Coordination .............. 04600109117

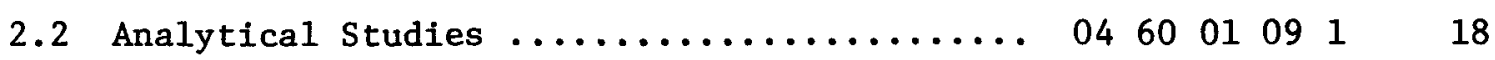

2.3 Water System Mockup of the FFM

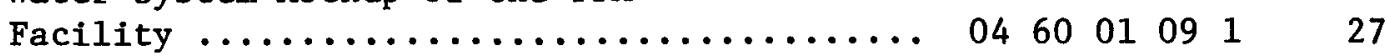

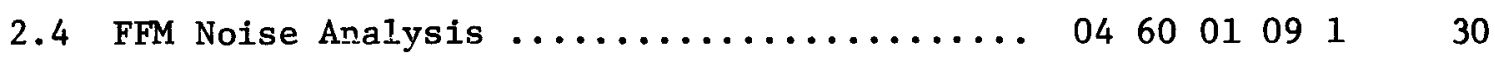

2.5 FFM Facility Activities ...................... 046001091132

3. SPRAY AND PRESSURE-SUPPRESSION POOL TECHNOLOGY ............. 39

3.1 Program objectives and Coordination ...... $04608001 \quad 1 \quad 39$

3.2 Nuclear Safety Pilot Plant .................. $046080011 \quad 40$

3.3 Radiation and Thermal Stability of Spray Solutions ..................... $046080011 \quad 40$

3. 4 Scale-Model Tests of Fission-Product Removal in Suppression Pools ........... 046080011

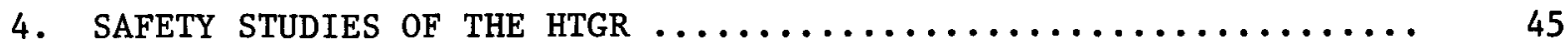

4.1 Studies of Reactions of Graphite

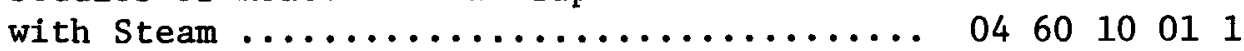

4.2 Fuel Integrity and Fission-Product

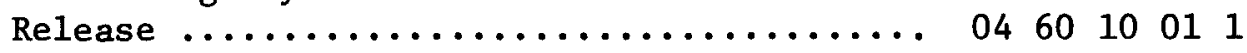

4.3 Fission Products in HTGR Coolant Circuits .. 046010011150 
5. PRESSURE VESSEL AND PIPING TECHNOLOGY $\ldots \ldots \ldots \ldots \ldots \ldots \ldots \ldots \ldots \ldots$

5.1 Heavy-Section Steel Technology Program ..... 046080031153

5.2 Design Criteria for Piping, Pumps, and Valves ................................. $046080031 \quad 61$

5.3 Experimental and Analytical Investigations

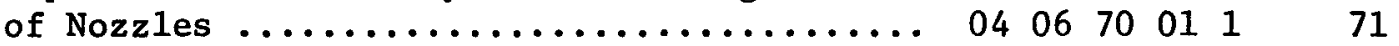

6. RDT STANDARDS PROGRAM ........................... 89

6.1 Program Objectives and Activities ........ 046080031189

6.2 Reactor Coolant System and Equipment Standards ............................... 04608003198

6.3 Instrumentation, Controls, and Electrical Equipment Standards ............. $04 \quad 6080031 \quad 101$

6.4 Programmatic and Procedural Standards ..... 046080031102

6.5 Materials and Fabrication Standards ....... 046080031103

7. GENERAL NUCLEAR SAFETY STUDIES $\ldots \ldots \ldots \ldots \ldots \ldots \ldots \ldots \ldots \ldots \ldots \ldots$

7.1 HTGR Safety Program Office ............ 046070011105

7.2 Ignition of Charcoal Adsorbers by Fission-Product Decay Heat ............ $02402090 \quad 106$

7.3 Effect of Velocity on Efficiency of Absolute Filter Media for Removal of Stainless Steel-UO ${ }_{2}$ Aerosol ............ $03402090 \quad 108$

7.4 Seismicity and Seismic Resistance of Nuclear Power Plants ........................ 04019109111

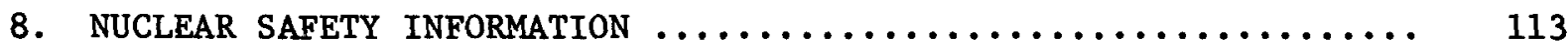

8.1 Nuclear Safety Information Center ........ $04607001 \quad 1 \quad 113$

8.2 Technical Progress Review Nuclear Safety ... 140201 


\begin{tabular}{|c|c|c|}
\hline Period Coves & & Report No. \\
\hline September-October & 1965 & ORNL-CF-65-11-2 \\
\hline November-December & 1965 & ORNL-CF-66-1-41 \\
\hline January-February & 1966 & ORNL-CF-66-3-13 \\
\hline March-April 1966 & & ORNL-CF-66-5-20 \\
\hline May-June 1966 & & ORNL-CF-66-7-48 \\
\hline July-August 1966 & & ORNL-TM-1636 \\
\hline September-October & 1966 & ORNL-TM-1680 \\
\hline November-December & 1966 & ORNL-TM- 1742 \\
\hline January-February & 1967 & ORNL-TM-1792 \\
\hline March-Apri1 1967 & & ORNL-TM-1864 \\
\hline May-June 1967 & & ORNL-TM-1913 \\
\hline July-August 1967 & & ORNL-TM-1986 \\
\hline September-October & 1967 & ORNL-TM-2057 \\
\hline November-December & 1967 & ORNL-TM-2095 \\
\hline January-February & 1968 & ORNL-TM-2164 \\
\hline March-April 1968 & & ORNL-TM-2230 \\
\hline May-June 1968 & & ORNL-TM-2283 \\
\hline July-August 1968 & & ORNL-TM-2368 \\
\hline September-October & 1968 & ORNL-TM-2425 \\
\hline November-December & 1968 & ORNL-TM-2479 \\
\hline January-February & 1969 & ORNL-TM-2533 \\
\hline March-Apri1 1969 & & ORNL-TM-2588 \\
\hline May-June 1969 & & ORNL-TM-2663 \\
\hline July-August 1969 & & ORNL-TM-2718 \\
\hline September-October & 1969 & ORNL-TM-2777 \\
\hline November-December & 1969 & ORNL-TM-2829 \\
\hline January-February & 1970 & ORNL-TM-2919 \\
\hline March-Apri1 1970 & & ORNL-TM-2984 \\
\hline May-June 1970 & & ORNL-TM-3061 \\
\hline July-August 1970 & & ORNL-TM-3122 \\
\hline September-October & 197 & ORNL-TM-3212 \\
\hline November-December & 197 & ORNL-TM-3263 \\
\hline January-February & 1971 & ORNL-TM-3342 \\
\hline
\end{tabular}


○

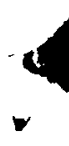

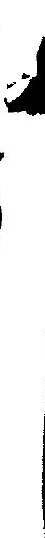


ABSTRACT

The accomplishments during the months of March and April in the research and development program under way at ORNL as part of the U.S. Atomic Energy Commission's Nuclear Safety Program are summarized. Much of this work is in general support of water-cooled power reactor technology, including LOFT and industry programs, and reflects current safety problems, such as measurements of prompt fuel element failure phenomena and the problems assocated with the long-term operation of containment spray systems. Several projects are also conducted in support of the high-temperature gas-cooled reactor (HTGR) and liquid-metal fast breeder reactor (LMFBR) programs. Other major projects are those on primary piping and steel pressure-vessel technology. They also include experimental investigations of the attachment of nozzles to shells and the implementation of joint AECPVRC programs on heavy-section steel technology and nuclear piping, pumps, and valves. Seismic considerations of particular significance in nuclear plant design are being evaluated in the seismic program. Several of the above projects are also directly related to another major undertaking; namely, the AEC's standards program, which entails development of engineering safeguards and the establishment of codes and standards for governmentowned or -sponsored reactor facilities. The recent activities of NSIC and the Nuclear Safety journal in behalf of the nuclear community are also discussed. Of particular interest in both of these activities is the recent emphasis on environmental effects. 
$\bullet$

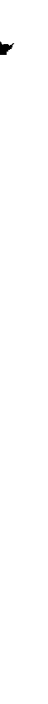


SUMMARY

1. FAILURE MODES OF ZIRCALOY-CLAD FUEL RODS

\subsection{Program Objectives and Coordination}

Support of ORNL work on fuel rod failure is now scheduled to be terminated at the end of FY-71. Therefore we are attempting to optimize the accomplishment of selected tasks during the period remaining.

\subsection{High-Temperature Properties and Metallurgical Evaluation of Zircaloy Cladding}

A 32-rod tube-burst experiment run at a heating rate of $10^{\circ} \mathrm{F} / \mathrm{sec}$ with rods internally pressurized to 700 psig was examined for coolant channel blockage. Maximum blockage was just over 50\%; maximum theoretical blockage under these conditions is $65 \%$. Blockage in the test bundle was also correlated with channel coefficients.

A method of integration is being devised to permit calculation of the depth of oxygen penetration into the wall of Zircaloy cladding during any specified temperature transient following a loss-of-coolant accident. The calculated oxygen-affected depth can be used to predict the ductileto-brittle transition temperature of the fuel rods.

Metallographic examination and microhardness measurements on the six unirradiated rods from the second fuel rod failure experiment in TREAT were completed. Ductile-to-brittle transition temperatures as high as $1800^{\circ} \mathrm{F}$ in some portions of the cladding wall were indicated by the hardness measurements.

\subsection{Cladding Behavior in Loss-of-Coolant Accident Environment}

A second seven-rod experiment with the rods internally pressurized to $350 \mathrm{psig}$ and powered to at least $15 \mathrm{~kW} / \mathrm{ft}$ is planned during May 1971. Examination of the data from the first seven-rod test has shown that pressure waves of 350-psi amplitude and 10-msec frequency occurred during the first $300 \mathrm{msec}$ of blowdown. 


\subsection{Transient Tests of Zircaloy-Clad Fuel Rod Clusters in TREAT}

The transient test program is presently inactive because funding is not available. Activation analysis for ${ }^{129} \mathrm{I}$ leached from the Zircaloy cladding of the center irradiated rod of experiment FRF-2 confirmed the minimal retention of iodine by the cladding, as previously inferred from the behavior of ${ }^{131} I$ in experiments FRF-1 and FRF-2.

\subsection{Rupture Tests of Irradiated Fuel Rods}

The results of fuel rod rupture tests were correlated with the u1timate strength of Zircaloy and with a failure model based on secondary creep. The $\mathrm{UO}_{2}$ fuel was dissolved from a group of unirradiated fuel rods as a checkout of our technique for removing the fuel from irraidated rods. The experimental assembly for the first multirod test in the hot-cell facility is being fitted with unirradiated tubes.

\section{LMFBR SAFETY STUDIES}

\subsection{Program Coordination}

The sequence of experiments in the FFM facility with bundle 1 was arranged for maximum efficiency with respect to the priority of the information to be obtained. A meeting at AEC headquarters was attended by WADCO, ANL, GE, AEC, and ORNL representatives to discuss fuel-simulating electrical heaters and the needs of the various AEC-supported out-ofpile experimental programs. The proposed ORNL heater development program appears to be the most efficient way of assuring the availability of heaters for all users when needed.

\subsection{Analytical Studies}

A series of transient heat-conduction calculations was performed to determine the effects of variation of heater insulation density and thermal conductivity on the transient response of the heaters. The effects of variations in density were far more pronounced than those of thermal conductivity. A calculation of the flows and temperature distribution within the FFM rod bundle with the central pin heated showed remarkable agreement with the experimental results. 


\subsection{Water System Mockup of the FFM Facility}

Experiments with a ten-channel inlet blockage in the scaled watercooled mockup showed that the blockage had insignificant effect on the flow in the heater zone compared with flow in the unblocked channels.

\subsection{FFM Noise Analysis}

The noise of the thermocouples installed on the side of the sheath of a heater tested in the single-rod heater test loop was analyzed. It appears that noise analysis may yield information on heat transfer and degree of flow turbulence in the FFM.

\subsection{FFM Facility Activities}

Bundle 1 was fabricated and installed in the FFM facility for testing. The alumel thermocouples are operative and appear to have an error range of $\pm 0.4^{\circ} \mathrm{F}$. Single-rod experiments at a heating rate of $8 \mathrm{~kW} / \mathrm{ft}$ gave adequate spread of temperatures to allow determination of cross-flow factors. Most heaters and all thermocouples for bundle 2 are on hand, and most quality-assurance procedures were completed. When the final shipment of rods is delivered, the inspections will be completed, and bundle 2 will be assembled and installed in the FFM facility for basic thermal fiydraulic tests.

3. SPRAY AND POOL PRESSURE-SUPPRESSION TECHNOLOGY

\subsection{Program Coordination}

The major effort in program coordination is effecting an orderly phase-out of the program work. Reports on all projects within the program will be issued in the next few months.

\subsection{Nuclear Safety Pilot Plant}

Final reporting of the particulate removal and elemental iodine experiments was completed. The remaining experiments on natural effects not reported to date will be summarized in a single report. 


\subsection{Radiation and Thermal Stability of Spray Solutions}

Work was continued on the generation of hydrogen from zinc-rich carbon-steel paint primers. The results to date indicate that the primers are a potential source of fairly large amounts of $\mathrm{H}_{2}$ and that under design-basis accident conditions the presence of a paint topcoat does not necessarily eliminate this potential.

Dynamic loop tests with borate and base-borate spray solutions containing sodium metavanadate continue to demonstrate the benefits of this additive in reducing radiolytic $\mathrm{H}_{2}$ generation. A tenfold reduction in $\mathrm{G}\left(\mathrm{H}_{2}\right)$ was observed for both solutions at a dose of $2 \times 10^{8}$ to $3 \times 10^{8}$ rad.

\subsection{Scale-Mode1 Tests of Fission-Product Removal in Suppression Pools}

Experiments were completed by General Electric, San Jose, with the $1 / 10,000$-scale model pressure-suppression pool in which $\mathrm{NaVO}_{3}$, a radiolytic $\mathrm{H}_{2}$ suppressant, was added, and postaccident removal conditions were simulated. The presence of $1.8 \times 10^{-3} \mathrm{M} \mathrm{NaVO}_{3}$ had little effect on $\mathrm{CH}_{3} \mathrm{I}$ removal by the system.

\section{Safety Studies of the HTGR}

\subsection{Studies of Reactions of Graphite with Steam}

Results are reported for the reaction of steam with $\mathrm{H}-327$ graphite at $1000^{\circ} \mathrm{C}$. The specimen employed in these studies exhibited considerable weakening in structural strength between 9.5 and $11 \%$ burnoff.

The second in-pile experiment was performed. Evaluation awaits analytical data.

\subsection{Fue1 Integrity and Fission-Product Release}

Annealing experiments with miniature bonded beds and loose particles showed that fission-product release is related to irradiation history and pyrolytic-carbon structure or, at least, method of fabrication. It remains to be shown whether the burnup effect is attributable to radiation damage to the coating or to other changes. 


\subsection{Fission Products in HTGR Coolant Circuits}

Gas samplers are being installed for fission-product surveillance experiments to be run at the Peach Bottom HTGR in May.

\section{PRESSURE VESSEL AND PIPING TECHNOLOGY}

\subsection{Heavy-Section Stee1 Technology Program}

The Fifth Annual Information Meeting of the Heavy-Section Steel Technology (HSST) Program was held on March 25 and 26, 1971, at the Oak Ridge Nationa1 Laboratory. Thirty-one papers were presented. There were 118 visitors in attendance, including 16 foreign visitors representing eight foreign countries.

Three HSST reports were issued; three reports were reviewed for publication; and three research subcontracts were extended. The fatigue crack propagation study in nuclear-grade-water environments was completed. The major conclusion reached was that the pertinent water environments do not have any significant effects on fatigue crack growth in plate steel and weldment.

The gamma-heating experiment in the Experimental Test Reactor (ETR) was completed and the results are being evaluated. A similar experiment in the Babcock and Wilcox Test Reactor (BAWTR) is planned.

Nine small steel pressure vessels fabricated from A 533, grade B, Class 1 steel that contained flaws were tested to failure. Six were 0.44 in. thick with a 3-in. outside diameter, while the remaining three were twice as large. An upward transition shift of about $30^{\circ} \mathrm{F}$ was noted for the larger vessels.

Three 6-in.-thick flawed tensile specimens are being fabricated. The fabrication of the intermediate test vessels is continuing, with delivery of the first vessel now scheduled for late June.

\subsection{Design Criteria for Piping, Pumps, and Valves}

Both analytical and experimental work are in progress under the ORNL portion of the joint AEC(ORNL)-Industry(PVRC) program to develop stress indices and flexibility factors for nuclear-service piping, pumps, and 
xiv

valves. Projects under the ORNL piping program are currently under way both at ORNL and at various facilities under subcontract to ORNL. Subcontract work is being done at Auburn University, the University of California, Battelle Memorial Institute, Combustion Engineering, Inc., Southwest Research Institute, and Westinghouse Research Laboratories. The results of various research tasks under this program were discussed at some length at the recent Third Annual Information Meeting on Studies in Applied Solid Mechanics held in Oak Ridge on April 26-28, 1971.

The experimental strain-gage results from the six ASA B16.9 tees tested to date are,summarized, and tabulated values for the maximum stress intensities are presented for internal pressure and individual applied moment loadings. These values and similar values for combined moment loadings will be used to prepare stress indices for codes and standards use. Finite-element stress analysis calculations were done for a 12- by 6-in. sched. -40 reducing tee loaded with internal pressure and with an in-plane bending moment loading on the branch pipe. Two different mesh arrangements were used. One was developed manually from detailed dimensional measurements of the tee, and the other was generated automatically by the computer. Both sets of analytical results compare quite favorably with the experimental strain-gage results.

Experimental results from the limit-load test of the second 6-in. stainless steel elbow were analyzed and compared with those from the previous test. The results confirm the earlier finding that stainless steel elbows have appreciably lower limit loads in bending than comparable carbon steel elbows.

Analytical work was completed and a report written on secondary stress indices for integral structural attachments on straight pipe.

\subsection{Experimental and Analytical Investigations of Nozzles}

Experimental and analytical studies of nozzles attached to shells and perforated models of pressure vessels are continuing. The current status of each project under the nozzles program was described at the annual information meeting held at ORNL on April 26-28, 1971.

Experimenta1 work in progress includes instrumentation of (1) the last in the series of single radial nozzles attached to spherical shells 
at the University of Tennessee, (2) the cluster of four radial nozzles attached to a spherical shell at Auburn University, and (3) the cluster of three nozzles attached to a flat plate, also at Auburn University. Models currently being tested include a $221 / 2^{\circ}$ nonradial nozzle attached to a spherical shell at the University of Tennessee and a cluster of two nozzles attached to a flat plate at Auburn University. The photoelastic studies conducted at Westinghouse Research Laboratories on two closely spaced nozzles attached to both a relatively thick-walled vessel and a thin-walled cylindrical vessel were completed.

At ORNL a parametric study of radial attachments of nozzles to spherical shells having triangular-pad reinforcement was completed for internal pressure loading. The models are currently being analyzed for moment and thermal loadings. In the study of compact reinforcement of radial nozzles attached to spherical shells, additional models were studied by finiteelement analysis. This information is being used in code-rule development work at Battelle Memorial Institute.

\section{RDT STANDARDS PROGRAM}

\subsection{Program Objectives and Activities}

The prime responsibility for managing the organization, preparation, and distribution of engineering standards was assigned to the Oak Ridge National Laboratory by the AEC Division of Reactor Development and Technology. The RDT Standards Group at ORNL prepares standards applicable to water-cooled reactor systems and liquid-metal-cooled systems. The standards for the liquid-metal-cooled systems are prepared in cooperation with the Liquid Metal Engineering Center (LMEC), which has the prime responsibility for these standards.

Typical program activities include (1) working cooperatively with projects under the direction of RDT in application of standards; (2) analyzing RDT project needs for standards; (3) reviewing and providing advisory services on standards prepared by other participating projects and organizations; (4) preparing and distributing new standards and reviewing and updating existing standards; and (5) maintaining close liaison with the LMEC Standards Office. 
During this period, four tentative standards were issued; one draft standard was submitted to RDT for approva1, and six draft standards were submitted to INC for use on the LOFT project and for the approval of RDT; drafts of three standards prepared by others were reviewed by ORNL; and RDT numbers were assigned for 39 new standards.

\subsection{Reactor Coolant System and Equipment Standards}

Work continued in preparing and reviewing drafts and in reviewing and evaluating comments received on valve, pump, static-seal, heat-exchanger, nuclear-code-supplement, demineralizer, and radioactive-wastesystem, and containment-spray-system standards. Two valve standards and one pump standard were transmitted to INC for use on the LOFT project.

\subsection{Instrumentation, Controls, and Electrical}

Equipment Standards

Work performed on instrumentation and electrical standards during this period included preparation of drafts; distribution of drafts for external review and comments; review and evaluation of comments received on standards prepared by ORNL; review of standards prepared by others and consolidation of comments for submittal to the requester; and submission of drafts to RDT for approva1.

\subsection{Programmatic and Procedural Standards}

Work continued in preparation of drafts, review and evaluation of comments, and revision of quality assurance, maintenance, seismic-design, and air-cleaning standards.

\subsection{Materials and Fabrication Standards}

Five standards concerned with various materials in reactor or radiation environments were prepared or revised during the report period. In three instances the draft was completed and distributed for comments. 
xvii

\section{General Nuclear Safety Studies}

\subsection{HTGR Safety Program Office}

The HTGR Safety Program Office further revised the HTGR safety program plan and prepared a paper entitled "Safety Research and High Temperature Gas-Cooled Reactor Design" for the issue of Nuclear Safety that is to be distributed at the 1971 Geneva Conference.

\subsection{Ignition of Charcoal Adsorbers by Fission- Product Decay Heat}

An experiment is being developed to demonstrate the consequences of heat generation in a charcoal bed resulting from radioactive decay of adsorbed iodine. An insulated charcoal test bed was constructed, calculations and experiments were performed to demonstrate that the production of the iodine source $\left({ }^{130} \mathrm{I}\right.$ as $\left.\mathrm{PdI}_{2}\right)$ in HFIR is possible, and work was done to develop a detailed procedure for preparing $\mathrm{PdI}_{2}$ powder from ${ }^{129} \mathrm{I}$ available as NaI.

\subsection{Effect of Velocity on Efficiency of Absolute Filter Media for Removal of Stainless Steel Oxide- $\mathrm{UO}_{2}$ Aerosol}

Efficiencies of commercial absolute-filter media for the removal of electric-arc-generated stainless steel oxide- $\mathrm{UO}_{2}$ aerosol are being measured as a function of face velocity. The particle size distribution of the test aerosol was determined (most particles are about $0.01 \mu$ in radius), and filter efficiency versus face velocity was determined for an additional filter medium.

\subsection{Seismicity and Seismic Resistance of Nuclear Power Plants}

The Shannon and Wilson-Agbabian Jacobsen Associates (SW-AJA) subcontract for the study of dynamic soil property measurements is being renewed for a second year of work. As suggested by AEC-DRDT, industry funds were obtained to support part of some proposed seismic studies. AEC-DRDT was then asked to provide matching funds.

Analysis of the data from the EGCR dynamic tests continues, and further forced-vibration tests at San Onofre are scheduled. A revised 
program plan for seismic research was prepared and submitted to AEC-DRDT following recent discussions on the last plan submitted.

\section{Nuclear Safety Information}

\subsection{Nuclear Safety Information Center}

The Nuclear Safety Information Center was established to collect, evaluate, and disseminate nuclear safety information to governmental agencies, research and educational institutions, and the nuclear industry. The Center's basic computer file now contains references on over 52,800 documents. Phase 1 of the computer file optimization program was completed. Approximately $30 \%$ of the previous $1 y$ required direct access space is now needed, and the improvement in performance is significant. NSIC responded to 356 inquiries, of which 144 were technical, during the period.

\subsection{Technical Progress Review Nuclear Safety}

The March-April 1971 issue of Nuclear Safety, a bimonthly Technical Progress Report sponsored by AEC's Division of Technical Information, was distributed in early April. The lead article was a review by F. A. Gifford, Jr., of the August 1970 IAEA-AEC Symposium on Environmental Aspects of Nuclear Power. Other articles were prepared by six non-ORNL and six ORNL authors, including five Nuclear Safety/NSIC staff members. Subsequent issues of Nuclear Safety through the March-Apri1 1972 issue are in various stages of development. 
1. FAILURE MODES OF ZIRCALOY-CLAD FUEL RODS

P. L. Rittenhouse, Program Coordinator

\subsection{PROGRAM OBJECTIVES AND COORDINATION}

(AEC Activity $046001 \quad 101$ )

P. L. Rittenhouse

The serious accidents considered "credible" in light-water reactors are associated with rupture of pipes in the primary system. This accident, the loss-of-coolant accident, results in rapid loss of system pressure and coolant and a subsequent increase in the temperature of the fuel cladding. Heatup of the cladding is, at first, primarily the result of redistribution of the heat stored in the fuel; at later times and higher temperatures, respectively, the decay heat of fission products and heat generated by the exothermic cladding (Zircaloy)-water reaction become predominant.

Although the probability of the loss-of-coolant accident is considered small, its potential consequences are of such severity that engineered safety features, such as emergency core-cooling systems, are provided to insure that the temperature transient following the accident can be terminated safely. Because it is important that the emergency core-cooling systems be effective, it is necessary to investigate thoroughly factors that may influence performance. Such factors include the effects of damage, blockage, and displacement of the reactor core that may result from failure of fuel rods. Some degree of damage would occur, even under the best of circumstances, because the temperatures reached by a significant fraction of the fuel rods in the core prior to transient turnaround 
and termination would be high enough to cause swelling and rupture of the cladding. This would reduce the cross-sectional area for passage of emergency coolant and perhaps restrict coolant entirely from local areas on some rods. At some, as yet unknown, degree of coolant channel blockage, termination of the temperature transient would be delayed sufficiently to significantly increase the probability of cladding embrittlement, subsequent fuel rod breakage, and melting. The effect of these latter events on cooling capability and safe accident termination is unknown but is possibly detrimental.

Because of the possibilities mentioned above, work has been under way to (1) examine the modes of failure of the Zircaloy cladding of the fuel rod in terms of accident conditions and reactor operating history, (2) determine to what extent fuel rod failures may affect emergency cooling capability, and ( 3 ) determine margins of safety relative to (1) and (2). Research and testing in these areas has been coordinated for the USAEC by ORNL. Since support for the ORNL work is not anticipated in FY-72, we have attempted to optimize the work planned for the remainder of FY-71. While we believe good progress has been made in obtaining answers to questions and resolving uncertainties related to fuel rod failure and the loss-of-coolant accident, there still exist several areas in which information vital to reactor safety should be obtained. It is also our belief that the AEC - the Regulatory Division in particular - needs inhouse research capability to assess the complex matters relating to fuel rod failure, the loss-of-coolant accident, emergency core-cooling systems, and licensing.

\subsection{HIGH-TEMPERATURE PROPERTIES AND METALLURGICAL EVALUATION OF ZIRCALOY CLADDING}

(AEC Activity $04 \quad 6001 \quad 101$ )

$$
\text { D. O. Hobson P. L. Rittenhouse }
$$

The failure modes of Zircaloy-clad fuel rods during a loss-of-coolant accident are dependent upon and sensitive to reactor operating conditions 
at the time of the accident, the core loading and its history, and the severity of the accident. Our continuing efforts to understand and characterize the behavior of the cladding and the effect of this behavior on core cooling capability are described in the sections that follow.

\section{Transient Burst Tests of Multirod Assemblies}

In the previous report in this series, ${ }^{1}$ we described the burst and flow tests of the rod bundle used in test 9 . This 32 rod bundle (30 of 32 rods were internally heated and pressurized) was heated at slightly less than $10^{\circ} \mathrm{F} / \mathrm{sec}$ from $600^{\circ} \mathrm{F}$ to a maximum temperature of approximately $1600^{\circ} \mathrm{F}$. The maximum internal pressure of the rods during the burst test was $700 \mathrm{psig}$, and a11 but two of the pressurized rods ruptured. The pressure drop in water flowing across the most heavily deformed section was increased by a factor of seven over that in an undeformed bundle.

After the flow test the bundle was mounted in epoxy, and 13 sections were cut, polished, and examined. The coolant channel blockages measured in this examination are shown in Fig. 1.1. The center of the spacer-grid of test bundle 9 was taken as the zero axial position. Maximum coolant channel blockage, the average of all channels in a section, was slightly more than $50 \%$ and occurred $31 / 2$ in. below the zero position. (Maximum individual coolant channel blockage was about 75\%.) Blockages of up to $25 \%$ also occurred above the spacer grid but decreased, as before, above the +4-in. position.

In Fig. 1.2 the coolant channel blockages in sections 3, 4, and 5 $(4,31 / 2$, and 3 in. below center, respectively) are shown as a function of channel coefficient. ${ }^{2}$ As in the past, blockage increased as a function of increasing channel coefficient but, as also observed earlier, the rate of blockage increase and the magnitude of the blockage were very strong functions of the internal pressure and the heating rate used in the burst test. It is interesting to note that extrapolations of the curve for section 4 in Fig. 1.2 yields almost exactly the value of blockage that is the theoretical maximum (i.e., that value calculated from expansion data on single tubes), 67 versus $65 \%$. 
ORNL-DWG $71-6410$

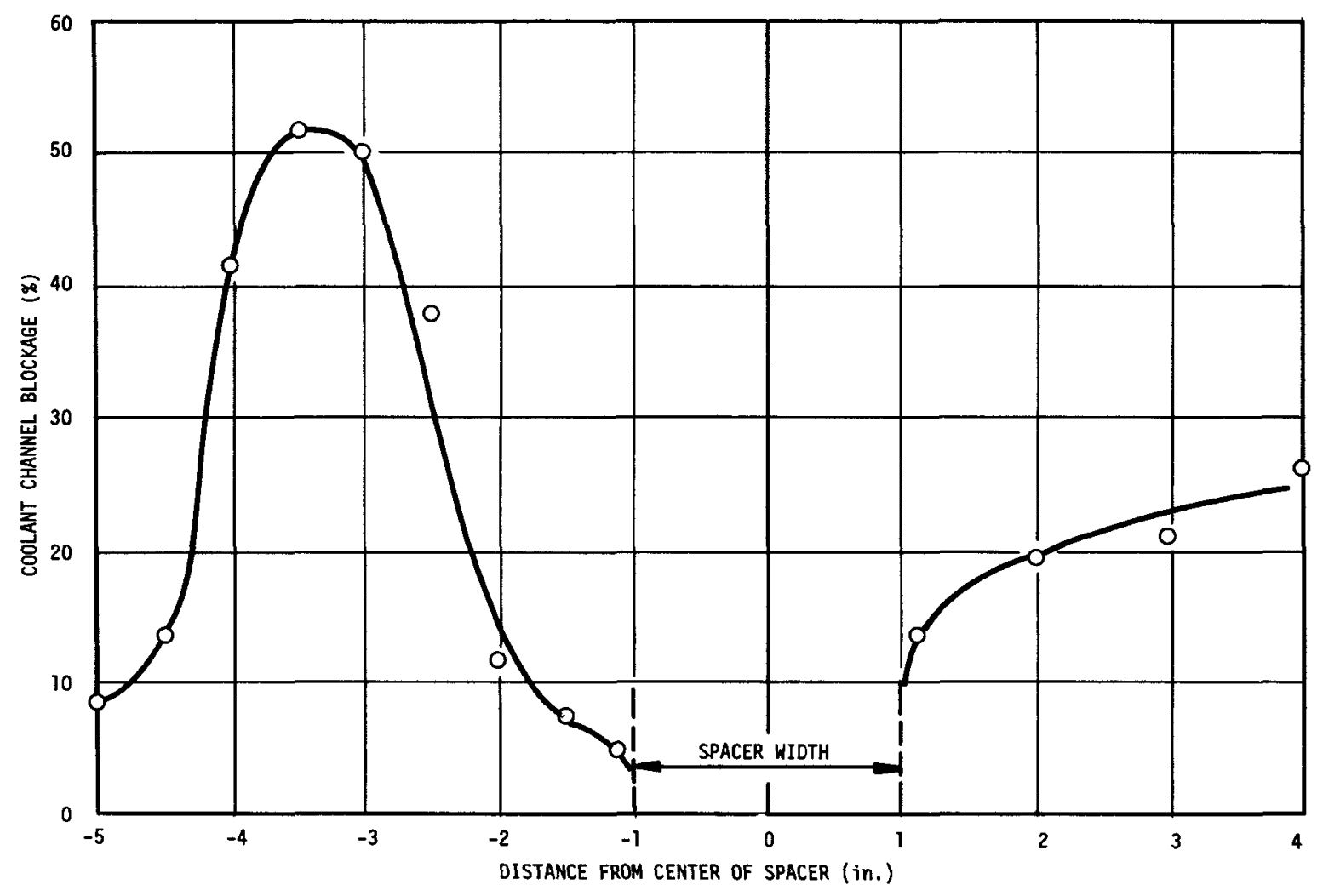

Fig. 1.1. Coolant Channel Blockage in Test 9. Coolant channel blockage is shown at nine positions below and four positions above the center of the 2-in. wide spacer-grid. Maximum blockage, about 50\%, occurred some $31 / 2$ in. below the center of the grid.

By the end of FY-71 we hope to complete both the burst testing and pressure drop experimentation on test bundle 10. This bundle is constructed of 32 rods clad with Zircaloy tubing supplied by Babcock \& Wilcox. Delay of this experiment has been caused by welding problems (burn-through of heater leads) and defects in some of the machined parts.

\section{Evaluation of Fuel Rod Embrittlement During}

\section{a Loss-of-Coolant Accident}

The results of the fuel rod embrittlement study were discussed in the previous report. ${ }^{1}$ These results were further analyzed in an effort to obtain a mathematical model of embrittlement as a function of the particular transient to which a rod might be subjected. Figure 1.3 is a 
ORNL-DWG 71-6411

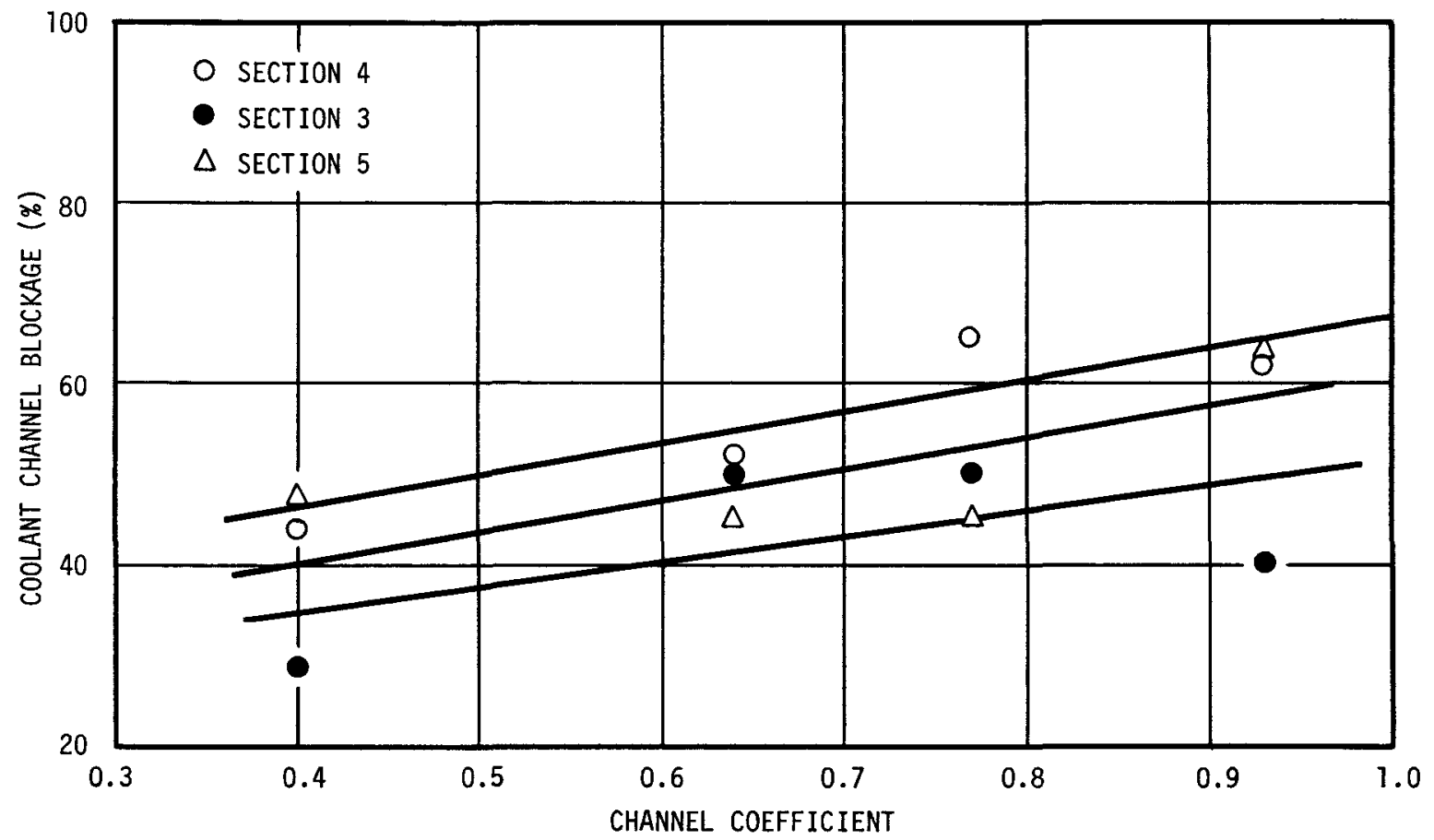

Fig. 1.2. Variation in Channel Blockage with Channel Coefficient. Sections 3, 4, and 5 were taken $4,31 / 2$, and 3 in. below the center of the spacer grid of test bundle 9 . The four groups of data defined by channel coefficients of $0.40,0.64,0.77$, and 0.93 are the averages for $4,4,6$, and 7 channels of the bundle, respectively.

plot of $\xi$, the width of one oxide layer and its underlying oxygen-stabilized alpha-phase layer, versus $\sqrt{t}$, where $t$ is exposure time in seconds. Specimens exposed at a constant temperature for different lengths of time form a straight line on the plot for each temperature considered. The slopes of these lines, plotted against temperature, form a curve that can be fitted by the following equation:

$$
\frac{\xi}{\sqrt{t}}=1.08 \times 10^{-5} T+5.15 \times 10^{-5} e^{0.0168(T-2200)}-1.70 \times 10^{-2},
$$

in which temperature $T$ is a function of time $t$ during a transient. Idealized accident transients can be fitted by an equation of the following form:

$$
T=\left(e^{a \sqrt{t}}-e^{b \sqrt{t}}\right)_{c}
$$




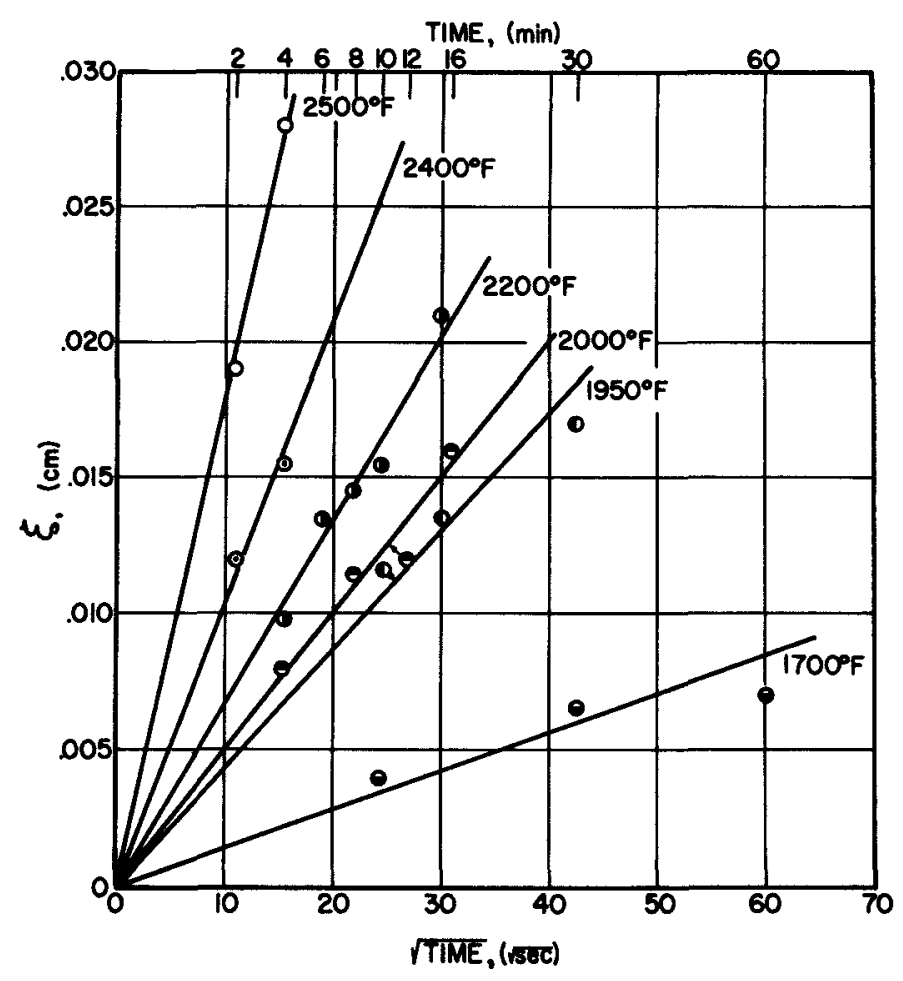

Fig. 1.3. Oxide Plus Oxygen-Stabilized Alpha-Phase Penetration Versus Steam Exposure Conditions. The combined depth of penetration of $\mathrm{ZrO}_{2}$ and oxygen-stabilized alpha-zirconium, $\xi$, is shown as a function of time and temperature.

where $a$ and $b$ are small negative numbers and $c$ is a scaling factor. Substitution of Eq. (2) into Eq. (1) and a rearrangement of terms give an equation that is integrable over the time period of the accident.

Integration provides a value of $\xi$ that can be used to obtain the ductile-to-brittle transition temperature for the rod by a method that is now being developed and will be discussed in the next report in this series.

\section{Metallographic Examination of Fuel Cladding} from Experiment FRF-2

Tubing cross sections taken at the positions of maximum expansion for each of the six outer rods from TREAT assembly FRF-2 were mounted and 
polished for metallographic examination and microhardness measurements. ${ }^{3}$ Some oxide buildup was found on the outer surface of each tube. These buildups varied around the circumference of each section, apparently due to rechanneling of steam in the blocked section of the bundle. Oxide was also found on the inner surface of the tubes, but not to the extent observed on the outer surfaces. Oxygen penetration produced oxygenstabilized alpha-phase layers under the oxide.

Hardness measurements were made at selected points on the cross section, as shown in Fig. 1.4, and the results are given in Table 1.1. Tubes 11 and 18 had sections of the wall broken away, but measurements were made with the pattern shown in Fig. 1.4 and terminated at the break. The nil-ductility transition temperatures in Table 1.1 were obtained from hardness measurements made at midwall positions in conjunction with the nil-ductility curve presented previously (see Fig. 1.4 in the previous report of this series ${ }^{1}$ ). The temperatures are approximate because the nil-ductility curve was based on a full-wal1-thickness tube; the tubes examined here were thinned by circumferential expansion. In general,

ORNL-DWG $71-4906$

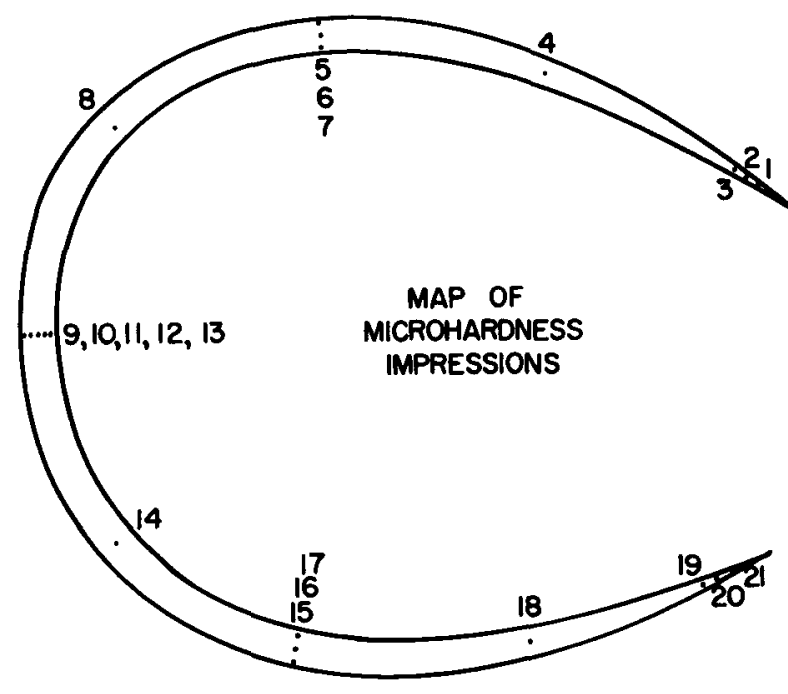

Fig. 1.4. Microhardness Measurement Positions on Schematic Representation of a Ruptured-Tube Cross Section. Postions of microhardness measurements in Table 1.1 are indicated by numerals 1 through 21 . 
Table 1.1. Microhardness of Tubes Used in TREAT Experiment FRF-2

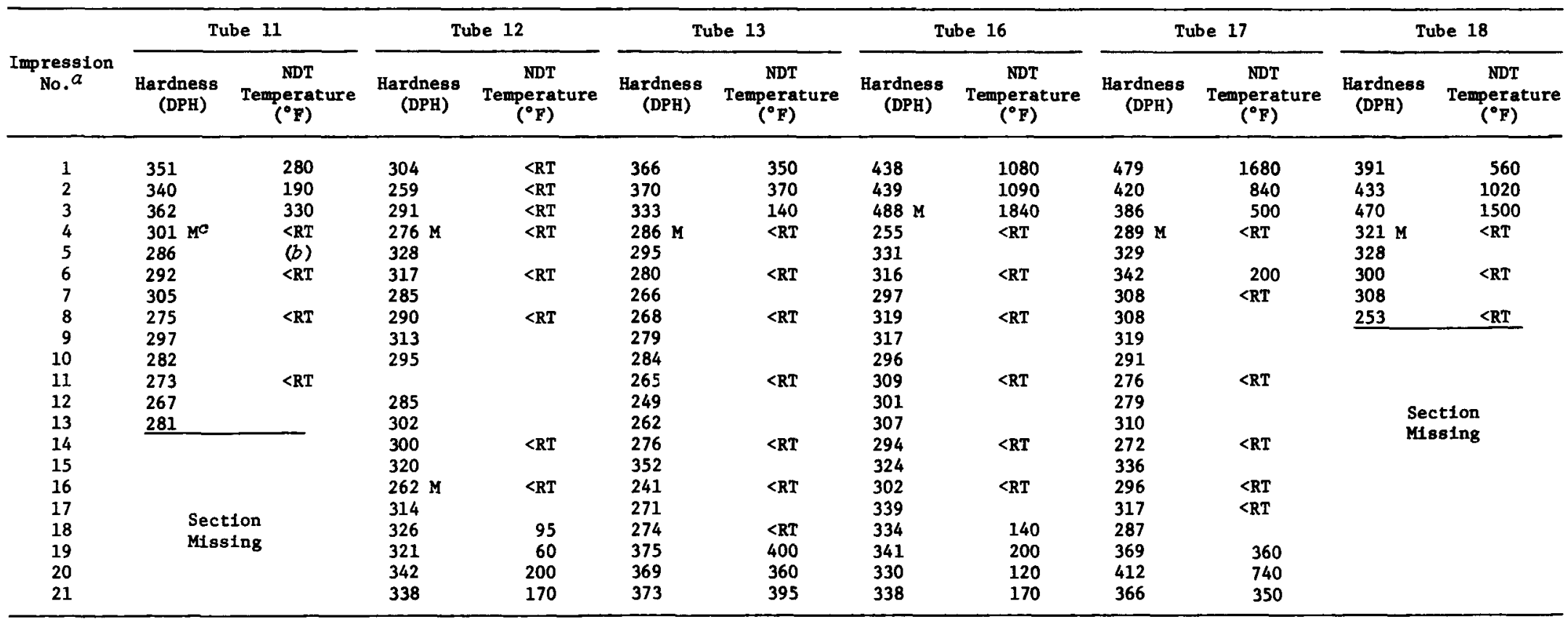

See Fig. 1.4

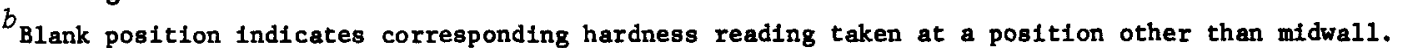

$c_{M}=$ Local maxima in oxide thickness. 
any midwall hardness greater than about $325 \mathrm{DPH}$ would indicate a nilductility transition temperature greater than room temperature for that particular section. Therefore all six TREAT tubes contained portions of wall that had no ductility at room temperature; two of the tubes accidently broke during handling.

\section{$\underline{\text { References }}$}

1. D. 0. Hobson, W. R. Gambill, and P. L. Rittenhouse, High-Temperature Properties and Metallurgical Evaluation of Zircaloy Cladding, pp. 2-12, ORNL Nuclear Safety Research and Development Program Bimonthly Report for January-February 1971, USAEC Report ORNL-TM-3342, Oak Ridge National Laboratory, May 1971.

2. D. O. Hobson and P. L. Rittenhouse, High-Temperature Properties and Metallurgical Evaluation of Zircaloy Cladding, pp. 2-15, ORNL Nuclear Safety Research and Development Program Bimonthly Report for NovemberDecember 1970, USAEC Report ORNL-TM-3263, Oak Ridge National Laboratory, March 1971.

3. R. A. Lorenz and G. W. Parker, Transient Tests of Zircaloy-Clad Fuel Rod Clusters in TREAT, Nuclear Safety Program Annu. Progr. Rept. Dec. 31, 1970, USAEC Report ORNL-4647, pp. 27-41, Oak Ridge National Laboratory, May 1971.

\subsection{CLADDING BEHAVIOR IN LOSS-OF-COOLANT ACCIDENT ENVIRONMENT}

(AEC Activity 046001101 )

C. G. Lawson

The response of heated rods constructed to simulate fuel rods and subjected to simultaneous loss of system coolant and pressure is being studied in an experimental facility that consists of a closed-cycle highpressure water-cooled loop that can be emptied and depressurized through a pipeline containing a dual rupture-disk assembly and a sharp-edged discharge orifice. A spray tank absorbs the thermal energy of the discharged water. Selection of an appropriate discharge orifice controls the depressurization and coolant-loss time to simulate a postulated loss-ofcoolant accident for either a PWR or a BWR. A preset program controls 
the test section power to simulate a change from full reactor power to appropriate decay-heat levels at any chosen time after the rupture disks fail for a bundle of seven 2-ft-long rods. The first experiment conducted in this facility was discussed previously, ${ }^{1}$ and preparations are now under way for the second experiment.

A second seven-rod bundle was assembled and installed in the blowdown engineering evaluation scoping test (BEEST) loop. It is planned to internally pressurize the rods with 350 psig of argon to simulate fissiongas pressure in fuel rods. Power input to each rod will be set at 15 $\mathrm{kw} / \mathrm{ft}$ or higher during steady-state operation of the BEEST Ioop and will be maintained during the first $5 \mathrm{sec}$ of the blowdown; it will then be lowered to $1.5 \mathrm{kw} / \mathrm{ft}$. Loop flooding and spray systems will be activated about $30 \mathrm{sec}$ after blowdown begins.

The pressure transient data from the earlier test ${ }^{1}$ of a seven-rod assembly were replotted from the magnetic tape. Pressure measurements taken in the test assembly during the first $300 \mathrm{msec}$ of blowdown show that decompression and compression waves of up to 350-psi amplitude occurred with a 10-msec frequency. During this same time period the temperature difference between the cladding and coolant decreased from 125 to $90^{\circ} \mathrm{F}$ and then increased to $110^{\circ} \mathrm{F}$. The initial decrease was probably the result of the decrease in saturation pressure, and we believe that the subsequent increase in the temperature difference may be evidence of a tendency toward flow stagnation. No indication of either departure from nucleate boiling or critical heat flux situations was observed during this early period.

Final reports describing the loop and experimental data from singleand seven-rod tests are being prepared.

\section{$\underline{\text { Reference }}$}

1. C. G. Lawson, Cladding Behavior in LOCA Envi ronment, Pp. 13-17, ORNL Nuclear Safety Research and Development Program Bimonthly Report for January-February 1971, USAEC Report ORNL-TM-3342, Oak Ridge Nationa1 Laboratory, May 1971. 


\subsection{TRANSIENT TESTS OF ZIRCALOY-CLAD FUEL ROD CLUSTERS IN TREAT}

(AEC Activity $046001 \quad 101$ )
R. A. Lorenz
G. W. Parker

Fuel rod failure experiments were conducted under loss-of-coolant accident conditions in TREAT with seven-rod clusters of Zircaloy-clad $\mathrm{UO}_{2}$ fuel rods in a flowing steam atmosphere. Heat generation in the enriched $\mathrm{UO}_{2}$ pellets provided heat-tranfer conditions between pellets and cladding closely simulating those expected in hypothesized accidents. Two experiments, designated FRF-1 and FRF-2, were performed with fuel rod internal pressures of 65 to 215 psia $\left(77^{\circ} \mathrm{F}\right)$ at cladding heatup rates of 75 to $80^{\circ} \mathrm{F} / \mathrm{sec}$ to maximum cladding temperatures of 1800 (FRF-1) and $2400^{\circ} \mathrm{F}$ (FRF-2). Work on additional experiments was stopped at midfiscal year because of funding limitations.

\section{Behavior of Fission-Product Iodine}

The fractional release of ${ }^{131} \mathrm{I}$ from fuel rods undergoing a loss-ofcoolant accident was anticipated to be considerably less than the fractional release of fission gases such as ${ }^{133} \mathrm{Xe}$ and ${ }^{85} \mathrm{Kr}$. For example, the ${ }^{131} \mathrm{I}$ release might be lowered by a factor of about 20 relative to the fission gases because of lower iodine transport from $\mathrm{UO}_{2}$ during normal reactor operation and retention of the iodine on the inner Zircaloy cladding surfaces. However, in experiment FRF-1, there was no significant difference in fractional release of the volatile fission products ${ }^{131} \mathrm{I}$ and ${ }^{137} \mathrm{Cs}$ and the fission gases ${ }^{133} \mathrm{Xe}$ and ${ }^{85} \mathrm{Kr} \cdot{ }^{1}$

Similarly, experiment FRF-2 did not show a large retention of ${ }^{131} \mathrm{I}$ compared with ${ }^{85} \mathrm{Kr}$. In search of direct evidence of retention of iodine by the Zircaloy cladding, we removed the $\mathrm{UO}_{2}$ from the fuel rods and used a basic leach on the Zircaloy to pick up any remaining iodine. Analyses were made for ${ }^{129} \mathrm{I}$ and ${ }^{137} \mathrm{Cs}$ on this sample and on two previous sample solutions to determine the relationship between ${ }^{131} \mathrm{I},{ }^{129} \mathrm{I}$, and ${ }^{137} \mathrm{Cs}$. A similar leaching procedure was successfully used earlier to analyze for iodine implanted and released to an unirradiated fuel rod, which was then heated. ${ }^{2}$ 
The results are given in Table 1.2. The release of ${ }^{129} \mathrm{I}$ was about 2.5 times that of ${ }^{131} \mathrm{I}$ and about equal to the release of ${ }^{137} \mathrm{Cs}$ and ${ }^{85} \mathrm{Kr}$. The expected large retention factor was not evident. A more thorough examination of the cladding would be required to verify the adequacy of the experimental procedures used.

At this point we are only able to repeat a conclusion stated in the final report of experiment FRF-1: the iodine behavior observed is "an

Table 1.2. Distribution of Volatile and Gaseous

Fission Products Released from $\mathrm{UO}_{2}$ Pellets of Irradiated Rod in TREAT Experiment FRF-2

\begin{tabular}{|c|c|c|c|c|}
\hline \multirow[t]{2}{*}{ Location } & \multicolumn{4}{|c|}{$\begin{array}{l}\text { Material Found in Each Location } \\
(\% \text { of total in center } \\
\text { irradiated rod })^{a}\end{array}$} \\
\hline & ${ }^{131} I$ & ${ }^{129} \mathrm{I}$ & ${ }^{137} \mathrm{Cs}$ & ${ }^{85} \mathrm{Kr}$ \\
\hline Primary vesse $1^{b}$ & 0.066 & 0.141 & 0.193 & \\
\hline $\begin{array}{l}\text { Filter-pack housing and } \\
\text { flow diffusers }\end{array}$ & 0.015 & 0.041 & 0.009 & \\
\hline $\begin{array}{l}\text { Diffusion coils, filters, } \\
\text { and charcoal beds }\end{array}$ & 0.034 & $0.083^{c}$ & 0.086 & \\
\hline Total outside rod & 0.115 & 0.265 & 0.288 & \\
\hline Center rod cladding ${ }^{d}$ & (e) & 0.059 & 0.034 & \\
\hline $\begin{array}{l}\text { Total released from } \\
\text { pellets }\end{array}$ & $>0.11$ & 0.32 & 0.32 & 0.48 \\
\hline \multicolumn{5}{|c|}{ 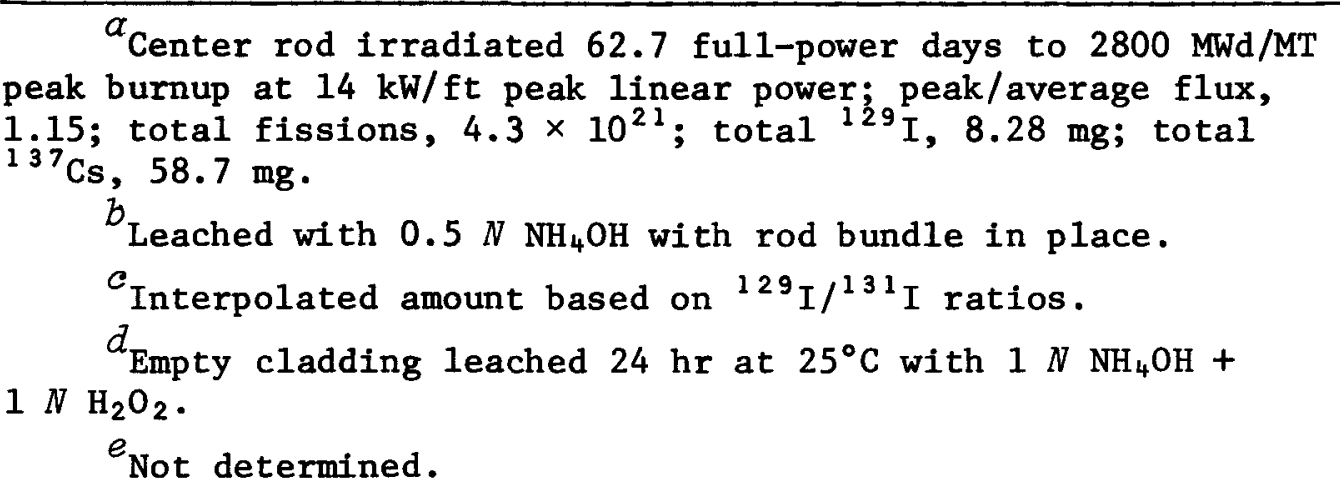 } \\
\hline
\end{tabular}


indication that credit should not be assumed for slower diffusional release of ${ }^{131} \mathrm{I}$ from $\mathrm{UO}_{2}$ during normal reactor operation and for retention of ${ }^{131} \mathrm{I}$ on the surfaces of Zircaloy cladding undergoing LOCA conditions."

\section{References}

1. R. A. Lorenz, D. 0. Hobson, and G. W. Parker, Final Report on the First Fuel Rod Failure Transient Test of a Zircaloy-Clad Fuel Rod Cluster in TREAT, USAEC Report ORNL-4635, Oak Ridge Nationa1 Laboratory, February 1971.

2. G. W. Parker, W. J. Martin, and G. E. Creek, Radioiodine Migration in a Heated Zircaloy-Clad Fuel Rod, pp. 47-51, OKiL Nuclear Safety Research and Development Program Bimonthly Report for November-December 1969, USAEC Report ORNL-TM-2829, Oak Ridge Nationa1 Laboratory, March 1970 .

\subsection{RUPTURE TESTS OF IRRADIATED FUEL RODS}

(AEC Activity 046001101 )

M. F. Osborne G. W. Parker

We have performed rupture tests of unirradiated Zircaloy cladding to investigate the potential effects of irradiation on the mechanical properties of the cladding. These tests simulate the conditions predicted for a hypothetical loss-of-coolant accident. A series of singlerod tests was completed, and equipment is being assembled for the first of two multirod tests.

\section{Single-Rod Tests}

The data obtained from the previously reported tests of single rods, ${ }^{1}$ which were heated by induction in a hot cell facility, were analyzed more thoroughly. Juenke and White conducted a variety of pressurized-tube burst experiments with Zircaloy and developed a failure model based on the secondary creep equation

$$
d \varepsilon / d t=A e^{-Q / R T} \sigma^{n},
$$


where $\varepsilon$ is strain, $t$ is time, $T$ is absolute temperature, $Q$ is activation energy for creep, $R$ is gas constant, $\sigma$ is effective stress, and $A$ and $n$ are parameters characteristic of the material. ${ }^{2}$ For transient test conditions in which the tube is pressurized and then heated at a linear rate, Juenke and White derived a relationship for effective stress, $S_{0}$ (in $\mathrm{kg} / \mathrm{mm}^{2}$ ), of the form

$$
S_{0}=B e^{-Q / n R T}\left(\frac{E B}{T^{2}}\right)^{1 / n},
$$

where the activation energy $Q$ and the material parameters $B$ and $n$ were determined by least squares analys is to be $85,700 \mathrm{cal} / \mathrm{mole}, 0.00738$, and 4.093, respectively. Other factors are

$$
\begin{aligned}
& E=\left[1-(1+\varepsilon)^{-2 n}\right] / 2 n, \\
& \varepsilon=\text { strain (diametral expansion), } \\
& R=\text { gas constant }=1.987 \mathrm{cal} / \mathrm{mole} \cdot{ }^{\circ} \mathrm{K}, \\
& T=\text { rupture temperature, }{ }^{\circ} \mathrm{K}, \\
& B=\text { heating rate, }{ }^{\circ} \mathrm{K} / \mathrm{sec} .
\end{aligned}
$$

This relationship, Eq. (2), is not intended to predict the strain at failure. However, Juenke and White suggest that it may be used to calculate the expected failure temperature in a fuel rod through the use of two assumptions: (1) set $\varepsilon=0.34$, which is the strain to cause rod-to-rod contact in a BWR fuel assembly, and (2) evaluate $S_{0}$ in the general relation for a closed-end tube in plastic flow,

$$
S_{0}=\frac{\sqrt{3}}{2} \frac{P r}{t}
$$

where $P$ is differential pressure, $r$ is initial internal radius, and $t$ is initial wall thickness of the tube.

Our data are shown in Fig. 1.5, along with Juenke and White's model evaluated for two heating rates and the ultimate strength curve from the data of Brassfield and others. ${ }^{3}$ Our data agree reasonably well with Juenke and White's model at temperatures below $\sim 2100^{\circ} \mathrm{F}$ and, in general, fall somewhat above the ultimate strength curve. At higher temperatures, rapid steam oxidation strengthens Zircaloy. This probably explains the 


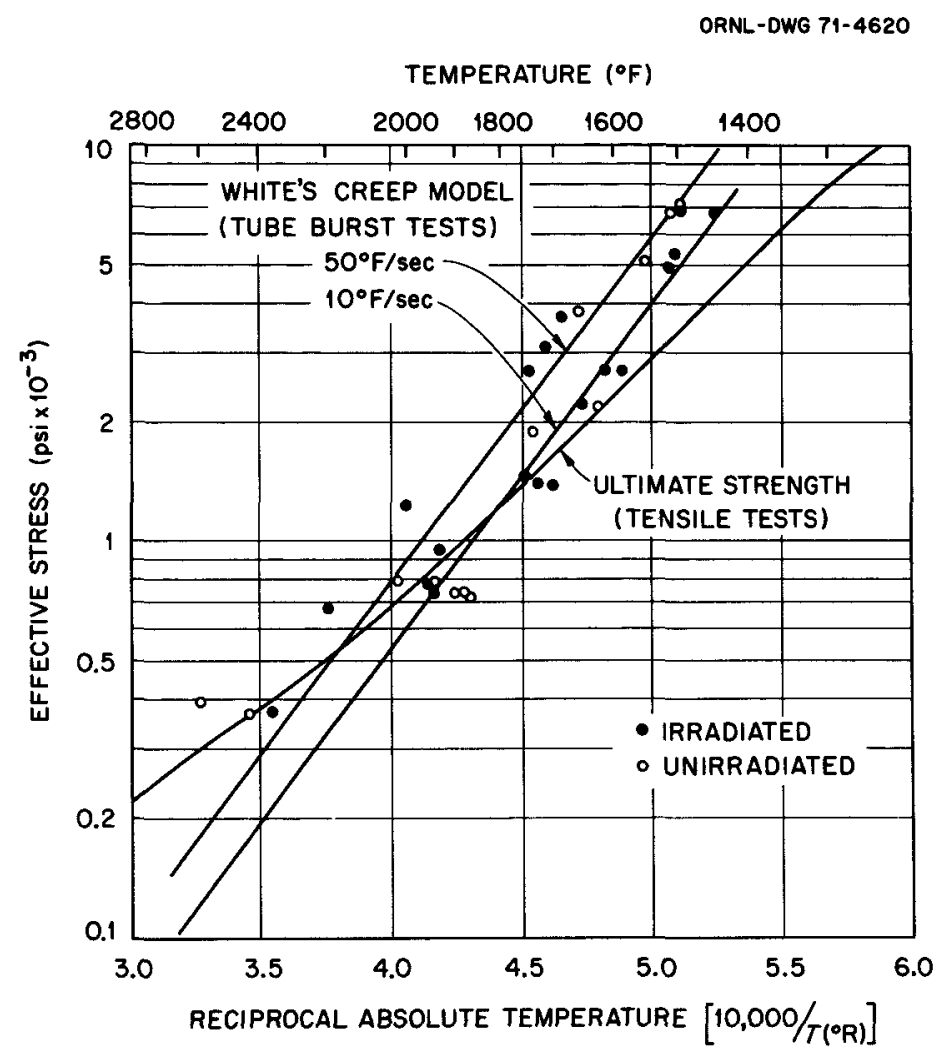

Fig. 1.5. Effective Stress Versus Temperature at Failure of Irradiated Fuel Rods. Data from ORNL single-rod tests compared with Juenke and White's creep model ${ }^{2}$ and with ultimate strength data of Brassfield and others. $^{3}$

deviation of our data in this region $\left(2200\right.$ to $\left.2600^{\circ} \mathrm{F}\right)$. Juenke and White observed a similar effect in steam atmosphere tests but did not provide a correlation.

\section{Multirod Tests}

Preparation for the series of multirod tests includes fabrication and operation of a fuel dissolver (to remove the $\mathrm{UO}_{2}$ fuel and fission products from irradiated rods) and construction of an in-cell assembly of 21 tubes in a PWR array $(5 \times 5$, with corner rods replaced by support rods). Each tube will be heated by an internal tungsten lamp and will be independently pressurized. 
Successful remote operation of the fuel dissolver was assured by removing the $\mathrm{UO}_{2}$ from a group of nine PWR-diameter rods, each 39 in. 1ong, with $8 \mathrm{~N} \mathrm{HNO}_{3}$. The low-temperature dissolution $\left(2110^{\circ} \mathrm{F}\right)$ was completed in about three days, and the Zircaloy cladding was salvaged intact. The same procedure will be used to remove the $\mathrm{UO}_{2}$ from similar rods, which were irradiated in assembly SA-1 (in the VBWR and in Dresden 1) to a maximum burnup of greater than 20,000 MWd/MT. All the components for the first multirod test, which will include unirradiated tubes only have been fabricated. The electric power, piping, and instrumentation are being installed, and the experimental assembly is being prepared in the hot cell.

\section{$\underline{\text { References }}$}

1. M. F. Osborne and G. W. Parker, Rupture Tests of Irradiated Fuel Rods, pp. 19-20, ORNL Nuclear Safety Research and Development Program Bimonthly Report for January-February 1971, USAEC Report ORNL-TM-3342, Oak Ridge National Laboratory, May 1971.

2. E. F. Juenke and J. F. White, Physical-Chemical Studies of Clad $\mathrm{UO}_{2}$ Under Reactor Accident Conditions, USAEC Report GEMP-731, General Electric Company, April 1970.

3. H. C. Brassfield, J. F. White, L. Sjodah1, and J. T. Bittel, Recommended Property and Reaction Kinetics Data for Use in Evaluating a Light-Water-Cooled Reactor Loss-of-Coolant Incident Involving Zircaloy 4 or 304-SS-Clad $\mathrm{UO}_{2}$, USAEC Report GEMP-482, General Electric Company, Apri1 1968. 
2. LMFBR SAFETY STUDIES

M. H. Fontana, Program Director

\subsection{FFM PROGRAM COORDINATION \\ (AEC Activity 046001091 )}

M. H. Fontana R. E. MacPherson

The fuel-failure mockup (FFM) is a large high-temperature sodium-cooled facility in which simulated LMFBR core segments (19-pin bundles) may be subjected to thermal and hydraulic testing at typical operating conditions. The core segments are simulated by cartridge electric heaters fabricated to duplicate fuel-pin geometry and assembled with spirally wrapped wirelike spacers containing internal thermocouple junctions. The program will provide information to be used by projects outside ORNL, such as the FFTF project (and in the future, LMFBR manufacturers), and therefore requires close coordination to remain responsive to program needs.

During this reporting period, FFM rod bundle 1 (scalloped can; thermocouples in wire wrapping only) was constructed and installed in the facility, and initial flow tests were started. The experimental program was scheduled for maximum efficiency and priority of information. Progress is being reported to the FFTF project by means of weekly telephone reports and monthly management reports. Delayed heater fabrication by the vendor has seriously affected the schedule for bundle 2 (instrumented hex-can wall; grounded-junction thermocouples in the wire wrapping and within the cladding). 
Program and budget proposals for FY-72 for the FFM and a companion heater development program were prepared and coordinated with WADCO and the AEC. A meeting was held at AEC headquarters on April 23 to discuss the proposed heater development program and its impact on AEC-sponsored out-of-pile experimental programs at ANL, HEDL, GE, and ORNL. It is essential that the necessary work be started now to assure that heaters which can meet the projected requirements will be available when needed. Direct communication between FFM and WARD personnel on the operating level has been taking place to assure rapid transfer of informal information.

\subsection{ANALYTICAL STUDIES}

(AEC Activity 04600109 1)
M. H. Fontana
A. Fukuda*
L. F. Parsly
J. L. Wantland

Analytical studies are being undertaken to plan the FFM experiments, interpret the results, and evaluate the performance of components. During this report period, two general heat transfer programs were employed in checking the performance of heater rods, and the computer program that models the flow in rod bundles was modified to include cross flow due to the wire wrapping and checked against measured temperatures.

\section{Effect of Variations in Thermal Conductivity and Density} of BN Insulation on Transient Heater Response

The nondestructive testing program for the special electric heaters being purchased for use as dummy fuel pins in the FFM includes a series of tests in which (1) the heating element is energized at near-rated power for approximately $1 \mathrm{sec}$, (2) the cladding is energized at near-rated power for about $1 \mathrm{sec}$, and (3) the heating element is energized at low power for long enough to attain a steady state. Infrared scans of the cladding

\footnotetext{
*Visiting scientist from Japan.
} 
surface temperature are made that usually show some variation in the temperature of the cladding surface along the heater.

To help interpret the test results, a series of calculations was made with the general heat transfer programs HEATING1 (Ref. 1) and HEATING3 (Ref. 2). In these calculations, variations in the density of the boron nitride insulation in the rod, the thermal conductivity of the BN insulation, and the heat release rate were assumed, and transient or steadystate temperatures in air were calculated, as applicable. Also steadystate temperatures for rods containing various defects and operating in sodium at rated power were calculated. The results of the calculations for the nondestructive tests will be used to help identify the defects that caused the surface temperature variations observed in the tests. The results for predicted behavior in sodium will then be used to determine whether a given defect is acceptable.

Results of the calculations are illustrated in Figs. 2.1 through 2.4. Figures 2.1 and 2.2 show the effect of changing BN insulation density and thermal conductivity on the temperature distribution in the heater during transient tests. The data indicate that decreasing the conductivity decreases the surface temperature slightly, while decreasing the density increases it sharply.

Figure 2.3 shows the effect of density and heat-generation rate on the surface temperature, and Fig. 2.4 similarly presents the effect of density and conductivity for tests in which either the heating element or the cladding was energized. Power inputs were those used in the nondestructive tests of the heaters, and heating time was $1 \mathrm{sec}$. This shows that low conductivity will cause a low surface temperature if the element is energized, while low density will cause a high surface temperature. When the cladding is energized, either defect produces a high surface temperature.

The calculations show that insulation density and heat release rate are important variables. Small changes in either cause significant changes in surface temperature. The thermal conductivity has only a slight effect on the surface temperature.

A report summarizing the results of these calculations is being written. 


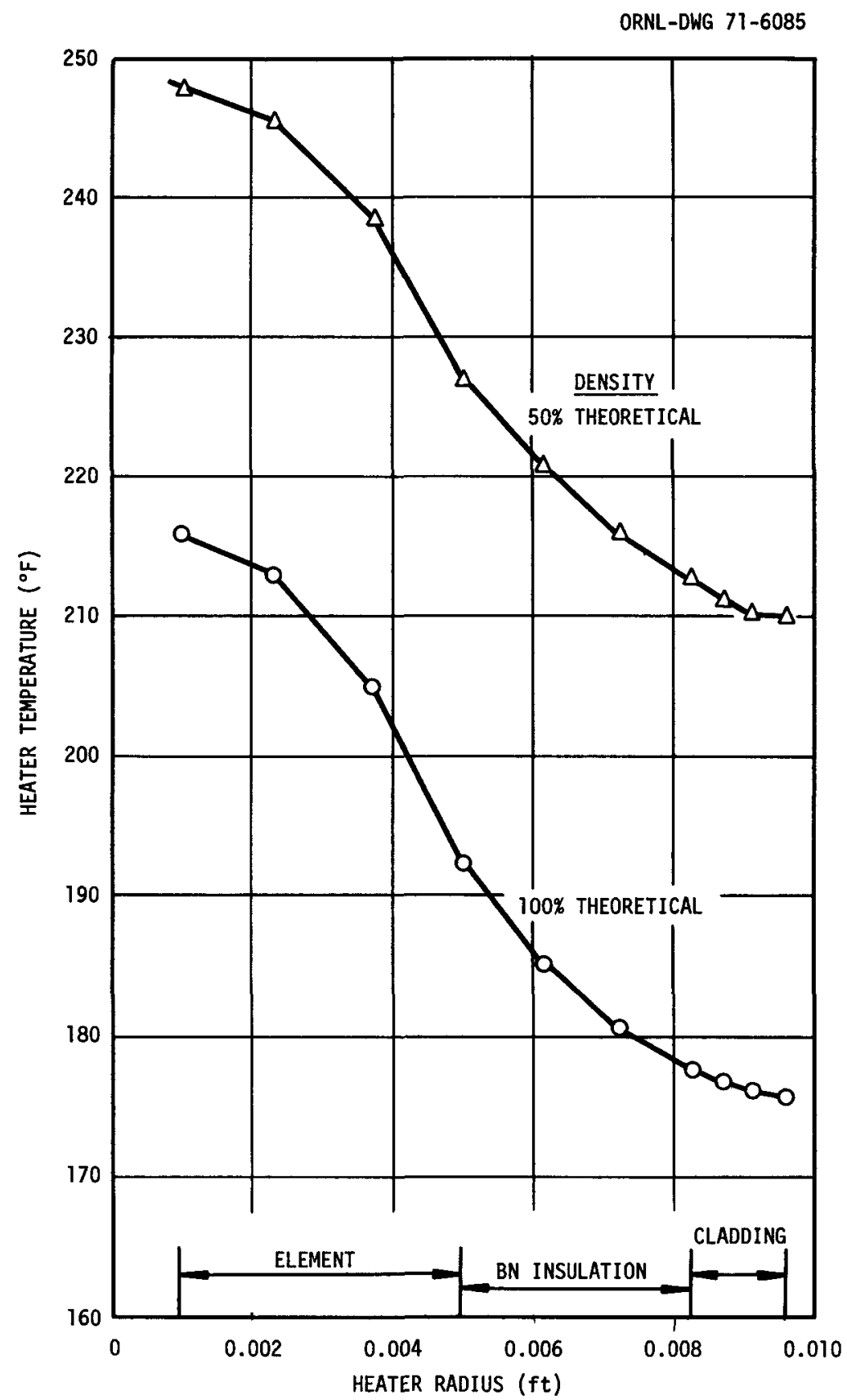

Fig. 2.1. Effect of Density of BN Insulation on FFM Heater Temperature. Heating element was energized at near-rated power for about I sec. 


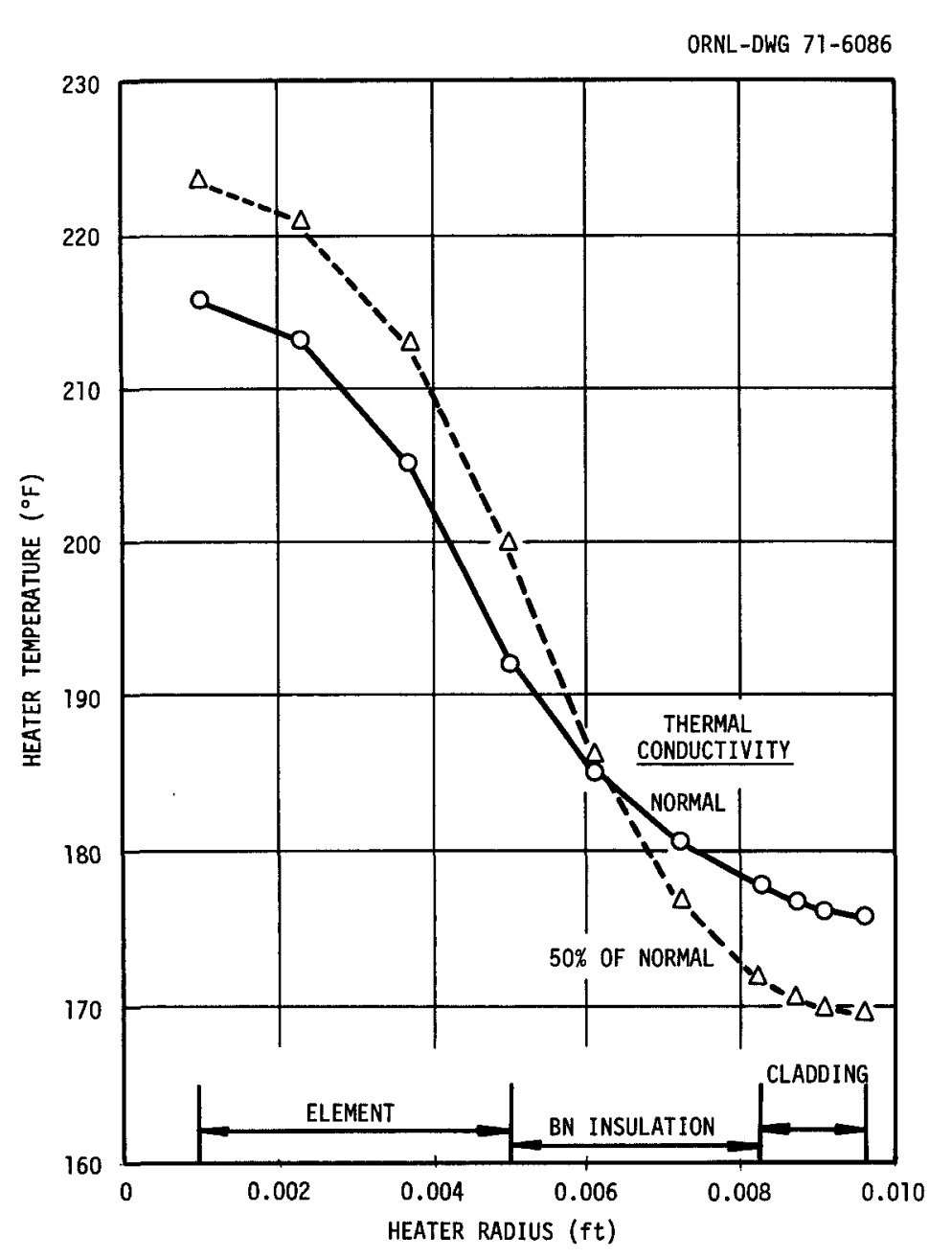

Fig. 2.2. Effect of Thermal Conductivity of BN Insulation on FFM Heater Temperature. Heating element was energized at near-rated power for about 1 sec.

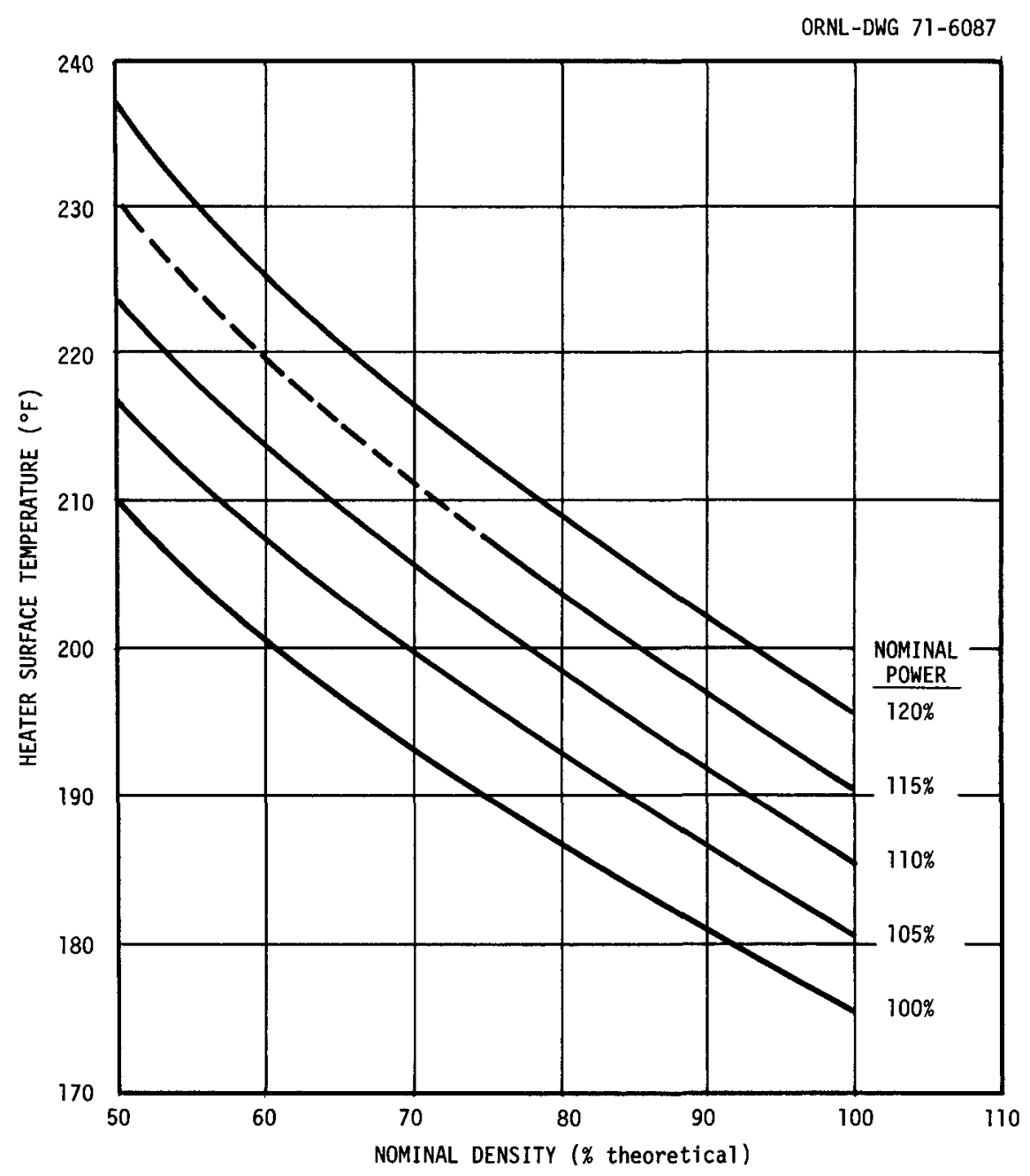

Fig. 2.3. Effect of BN Insulation Density and Heat-Generation Rate on Heater Surface Temperature After 1 sec. 


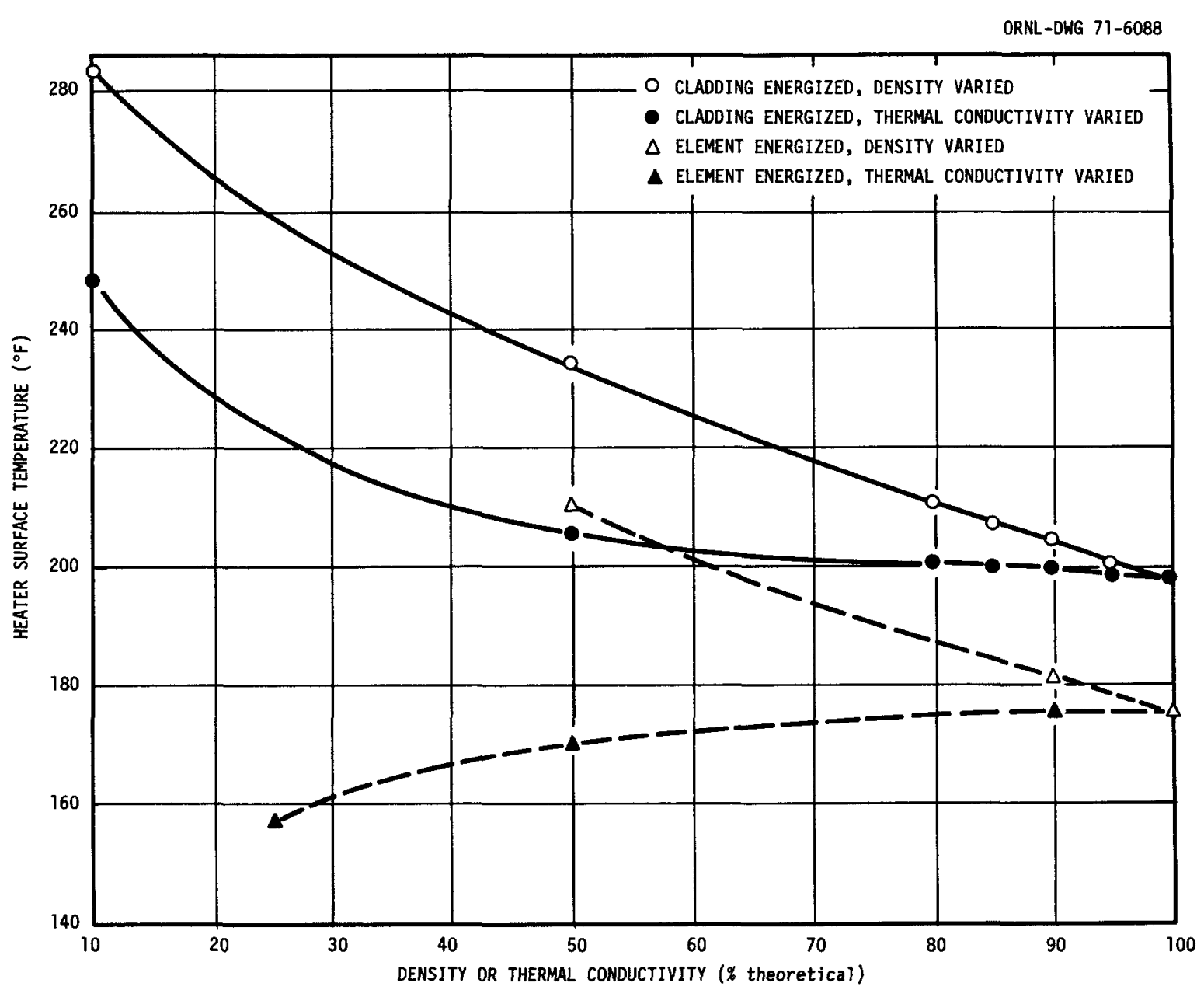

Fig. 2.4. Effect of BN Insulation Density and Thermal Conductivity on Heater Surface Temperature in Tests with Either the Heating Element or the Cladding Energized 1 sec.

\section{Mathematical Models of Flow in Rod Bundles}

The computer program $\emptyset$ RRIBLE was modified to include the effects of sweeping cross flow due to the helical wire wrapping. ${ }^{3}$ A different relationship for the diversion cross flow than was used previously ${ }^{4}$ was developed and incorporated. This relationship was derived on the premise that the diversion cross flow between adjacent channels is proportional to the square root of the local pressure difference between two identical, parallel, interconnected channels, one of which has zero axial flow at the inlet. The axial momentum equations for the two channels were coupled with this diversion cross-flow relationship to eliminate the pressure 
terms. The resulting ordinary differential equation was solved with the boundary condition of equal axial mass flows in the two channels as the length increases indefinitely. The equation implicitly expresses the local diversion cross flow as a function of the two local axial flows.

The following empirical expression was developed to approximate the diversion cross flow explicitly:

$$
\begin{aligned}
W_{D_{i}}= & 0.03 C_{D} \frac{w_{i+1}-w_{i}}{\left|w_{i+1}-w_{i}\right|}\left(w_{i+1}+w_{i}\right) \\
& \times\left(\frac{8\left|w_{i+1}-w_{i}\right|}{w_{i+1}+w_{i}}\right)^{2 / 3}\left[4+\left(\frac{8\left|w_{i+1}-w_{i}\right|}{w_{i+1}+w_{i}}\right)^{2 / 3}\right],
\end{aligned}
$$

where

$$
\begin{aligned}
W_{D_{i}}= & \text { diversion cross flow from channel } i+1 \text { to channel } i . \\
& 1 \mathrm{~b}_{\mathrm{m}} / \mathrm{hr} \cdot \mathrm{ft}^{2}, \\
W_{i, i+1}= & \text { axial mass flow in channel } i, i+1,1 \mathrm{~b}_{\mathrm{m}} / \mathrm{hr} \cdot \mathrm{ft}^{2}, \\
C_{D}= & \text { dimensionless diversion cross-flow coefficient. }
\end{aligned}
$$

Appropriate values of $C_{D}$ were obtained from experimental data for transverse flow across staggered tube banks.

The present version of $\emptyset$ RRIBLE was written for the configuration of the FFM bundle 2 test section. This differs from the FFM bundle 1 test section (which is now in operation) in several respects. Bundle 1 has a circular duct with dummy partial rods to simulate an infinite array. Bundle 2 has a hexagonal duct with rounded corners. The wire wrapping in bundle 1 is a left-hand helix, with the wire being in channels at the start of the heated section. The wire wrapping in bundle 2 is a righthand helix with the wires being in gaps at the start of the heated section. (The bundles are of different lengths, but this can be handled mathematically by $\emptyset$ RRIBLE.) By making a slight change in $\emptyset$ RRIBLE to account for the different "phase" of the wire wrapping, results can be obtained that can be interpreted in terms of the FFM bundle 1 test section, except near the peripheral flow channels, which have different configurations. 
For reference, Fig. 2.5 shows the rod-numbering system, the channe1numbering system, and the locations of the wire-wrapped thermocouples in the FFM bundle 1 test section. The small circles around the rods show the rotational orientations of the wire-wrapped thermocouples, and the numbers in these circles indicate their axial locations in inches downstream from the start of the heated section.

$\emptyset$ RRIBLE was changed as indicated above, and a preliminary comparison of uncorrected experimental data and predictions of the mathematical model was made. The FFM was operated with only the central rod (No. 1) heated

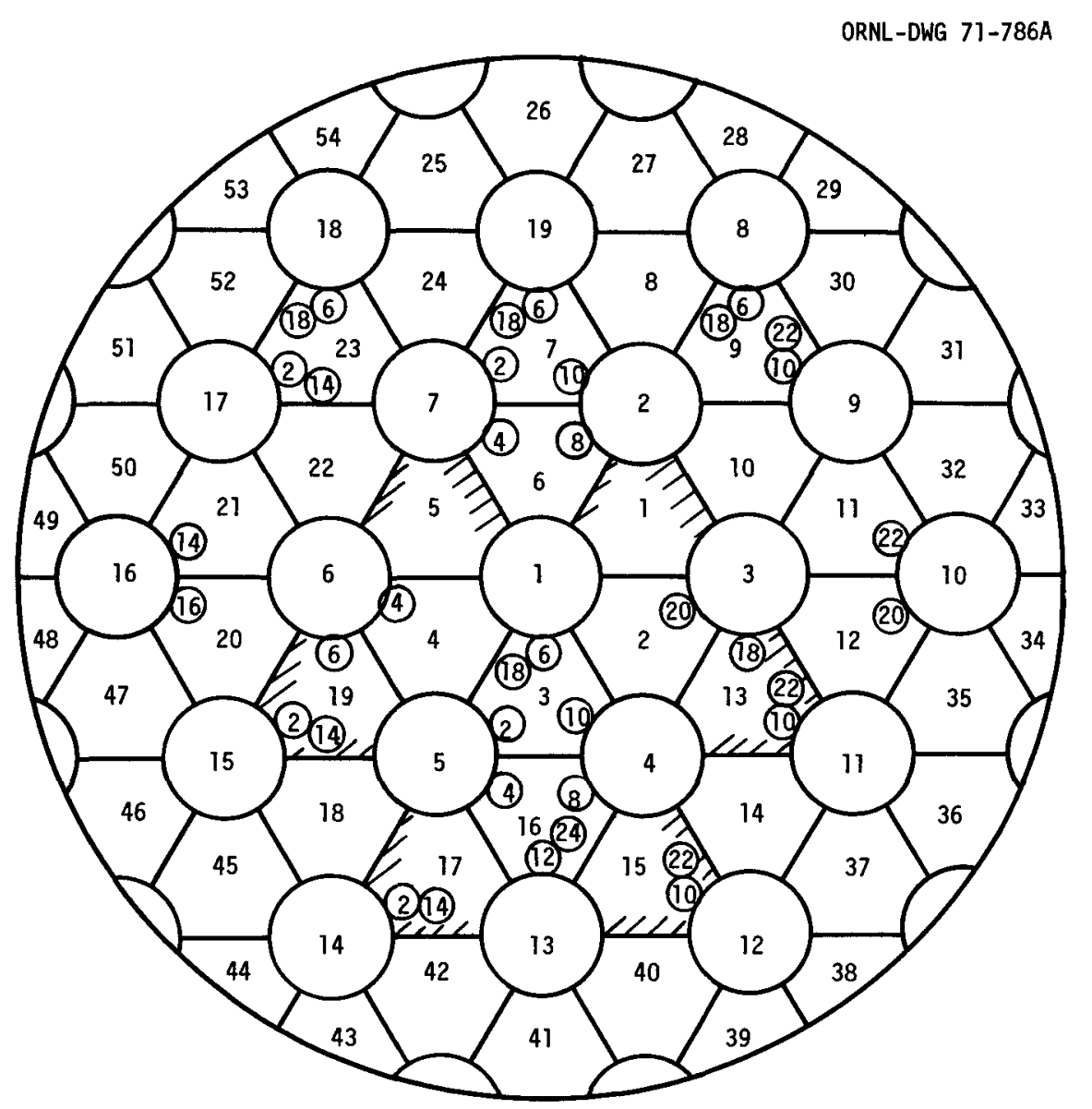

Fig. 2.5. Wire-Wrapped Thermocouple Locations in the FFM Bundle I Test Section. The small circles around the rods show the rotational orientations of the thermocouples, and the numbers in the circles indicate their axial locations in inches downstream from the start of the heated section. 
at $8 \mathrm{~kW} / \mathrm{ft}$ and a total sodium flow of $54 \mathrm{gpm}$. An analogous case was executed with $\emptyset$ RRIBLE for the same operating conditions and a priori-chosen cross-flow coefficients. This preliminary comparison is shown in Fig. 2.6 as plots of channel temperature rise versus length along the heated section. The upper plot displays experimentally determined temperatures. The numbers by the points indicate the number of the channel in which the thermocouple was located (see Fig. 2.5). The two temperatures labeled $3 \mathrm{H}$ were measured by thermocouples located in channel 3 adjacent to the thermocouples in the wire wrapping around rod 1, the heated rod. It is apparent that these thermocouples measured a temperature intermediate between the sodium temperature and the rod temperature. The lower plot displays the analogous channel temperatures computed with $\emptyset$ RRIBLE.

The agreement of these preliminary results is quite good. The effect of sweeping cross flow due to the helical wire wrapping appears to be significant. From such comparisons of results, the validity of the mathematical model should be ascertained and the appropriate values for the cross-flow coefficients determined.

\section{References}

1. W. D. Turner and J. S. Crowel1, Notes on HEATING - An IBM 360 Heat Conduction Program, USAEC Report CTC-INF-980, Oak Ridge Gaseous Diffusion Plant, November 1969.

2. W. D. Turner and M. Siman-Tov, HEATING3 - An IBM 360 Heat Conduction Program, USAEC Report ORNL-TM-3208, Oak Ridge National Laboratory, February 1971 .

3. M. H. Fontana et al., Analytical Studies, pp. 22-27, ORNL Nuclear Safety Research and Development Program Bimonthly Report for JanuaryFebruary 1971, USAEC Report ORNL-TM-3342, Oak Ridge National Laboratory, May 1971.

4. M. H. Fontana et al., Analytical Studies, pp. 30-36, ORNL Nuclear Safety Research and Development Program Bimonthly Report for NovemberDecember 1970, USAEC Report ORNL-TM-3263, Oak Ridge National Laboratory, March 1971. 
ORNL-DWG 71-6089

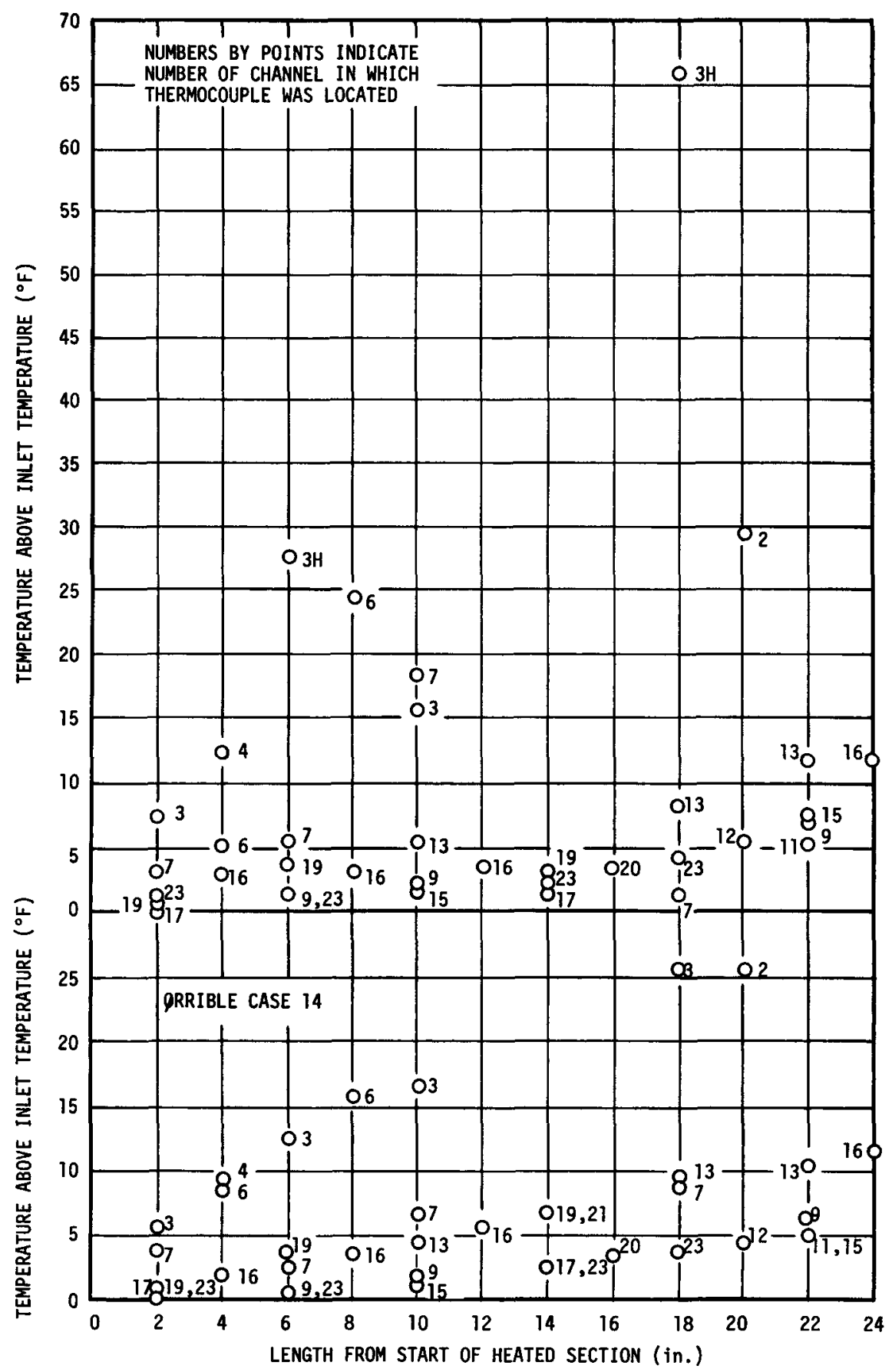

Fig. 2.6. Preliminary Comparison of Unconnected FFM Data and Results from $\emptyset$ RRIBLE. Central rod heated at $8 \mathrm{~kW} / \mathrm{ft}$; total sodium flow, $54 \mathrm{gpm}$. 


\subsection{WATER SYSTEM MOCKUP OF THE FFM FACIEITY \\ (AEC Activity 04600109 1) \\ W. R. Gambill}

Simulations with water coolant in the mockup of the FFM facility will provide an independent check on the FFM sodium data with respect to the effect of inlet and internal partial flow blockages on the downstream flow distribution, as well as an indication of optimal locations for later temperature measurements. During this reporting period, tests 8 , 9, and 10 were conducted with the inlet plate blocking ten subchannels. The data from these tests, summarized in Tables 2.1 and 2.2 , * show no major

*In Table 2.3, p. 29, of the preceding report in this series, which was similar to Table 2.2 of this report, the entries in the last two columns were percentages. Please make this notation on your copy.

Table 2.1. FFM Mockup Test Conditions with TenChannel Blockage Plate at Inlet

\begin{tabular}{|c|c|c|c|}
\hline Test Conditions & Run 8 & Run 9 & Run 10 \\
\hline Q, volumetric flow rate, gpm & 514.0 & 116.6 & 59.0 \\
\hline$V_{m n}$, mean coolant velocity, ${ }^{a}$ fps & 26.7 & 6.1 & 3.1 \\
\hline $\begin{array}{l}\text { Mean } t_{b}, i n^{\prime} \text { mean inlet bulk water } \\
\text { temperature, }{ }^{\circ} \mathrm{C}\end{array}$ & 31.3 & 28.2 & 29.4 \\
\hline$N_{R e, i n}$, inlet Reynolds number & $1.01 \times 10^{5}$ & $0.22 \times 10^{5}$ & $0.11 \times 10^{5}$ \\
\hline $\begin{array}{l}\phi_{0} \text {, heat } f l u x \text { in heater rod, } \\
\mathrm{Btu} / \mathrm{hr} \cdot \mathrm{ft}^{2}\end{array}$ & $5.12 \times 10^{5}$ & $2.44 \times 10^{5}$ & $1.61 \times 10^{5}$ \\
\hline \multicolumn{4}{|l|}{$\begin{array}{l}\text { Max } \Delta t_{\text {radial, }} \text { radial difference in } \\
\text { bulk water temperature at each of } \\
\text { three axial stations: } b\end{array}$} \\
\hline S1 & 0.5 & 1.1 & 1.3 \\
\hline $\mathrm{s} 2$ & 1.4 & 2.1 & 2.7 \\
\hline S3 & 1.3 & 2.6 & 3.8 \\
\hline
\end{tabular}

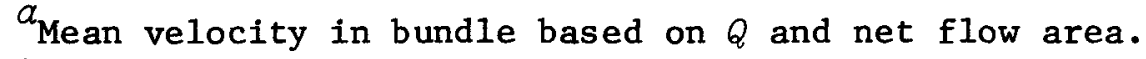

$b_{\text {Station }} 1$ is $21 \mathrm{in}$. above rod-bundle base and stations 2 and 3 are 39 and 51 in. above base, respectively. 
Table 2.2. Results of FFM Mockup Tests with

Ten-Channel Blockage Plate at Inlet

\begin{tabular}{|c|c|c|c|}
\hline & Run 8 & Run 9 & Run 10 \\
\hline \multicolumn{4}{|l|}{ Mean inferred velocity $a$} \\
\hline $\begin{array}{l}V_{\text {inf }}, \text { fps } \\
\text { Number points }\end{array}$ & $\begin{array}{l}27.3 \\
18\end{array}$ & $\begin{array}{l}6.8 \\
18\end{array}$ & $\begin{array}{l}3.5 \\
18\end{array}$ \\
\hline $\begin{array}{l}\text { Average deviation of mean ve- } \\
\text { locity from mean } V_{i n f}, \%\end{array}$ & 2.4 & 12.4 & 14.1 \\
\hline $\begin{array}{l}\text { Ratio of mean velocity, } V_{m n} \text {, to } \\
\text { local minimum inferred velocity, } \\
\left(V_{x}\right)_{\text {inf, min }}\end{array}$ & 1.31 & 1.09 & 0.97 \\
\hline $\begin{array}{l}K_{\text {adj, adjusted numerical factor }} \\
\text { in velocity inference equation } a\end{array}$ & 0.0394 & 0.0359 & 0.0354 \\
\hline Maximum value of $t_{b, s}-t_{b}, \csc _{c} b^{b} \mathrm{C}$ & -0.1 & -1.2 & -0.4 \\
\hline $\begin{array}{l}\text { Range of ratios of maximum experi- } \\
\text { mental radial temperature drop } \\
\text { to calculated unmixed radial } \\
\text { temperature drop, } \%\end{array}$ & $11-42$ & $24-30$ & $26-28$ \\
\hline $\begin{array}{l}\text { Ratio of experimental to cal- } \\
\text { culated unmixed axial tempera- } \\
\text { ture rise for central sub- } \\
\text { channels between stations } 1 \\
\text { and } 3, \%\end{array}$ & 210 & 210 & 14 \\
\hline \multicolumn{4}{|c|}{$\begin{array}{l}a_{\text {Determined for }} K=0.0404 \text {, as for previously reported } \\
\text { data; } K \text { is numerical factor in velocity inference equation, } \\
V=K F_{p p} h^{1.205} \text {, in which } F_{p p} \text { is a physical properties factor } \\
\text { and } h \text { is the local heat transfer coefficient. } \\
b_{t b, s} \text { is station-average water temperature (six read- } \\
\text { ings) and } t_{b}, c s c \text { is central-subchannel-average water tempera- } \\
\text { ture (three readings). }\end{array}$} \\
\hline
\end{tabular}

effect of a ten-subchannel inlet blockage on the downstream velocity structure. The mean of the velocities inferred from the thermocouples not above the blockage plate is $11 \%$ larger than the mean of those inferred from the couples above the plate. A comparison was made of the data from test 6 (reference bundle) with those from test 8 (with blockage plate). In both these tests the Reynolds number was $1.0 \times 10^{5}$ and the heat flux was $5.1 \times 10^{5} \mathrm{Btu} / \mathrm{hr} \cdot \mathrm{ft}^{2}$. For the combined data, $86 \%$ of the subchannel 
water temperatures fell within the range 33 to $35^{\circ} \mathrm{C}, 92 \%$ of the heater outer-wall temperatures within the range 70 to $80^{\circ} \mathrm{C}$, and $89 \%$ of the $10 \mathrm{cal}$ inferred velocities between 24 and $30 \mathrm{fps}$.

Bubble-trail flow-visualization tests (and one film strip) were made following tests 8,9 , and 10 at flow rates of $59,117,255$, and $510 \mathrm{gpm}$. The results were generally the same as for the reference bundle, that is, the bubbles first became visible at the outer periphery of the bundle at a height of 23 to 27 in. above the bundle base.

To determine the variability of heater-wall temperature associated with moving the thermocouple head, both axially and circumferentially, the spring-loaded assembly was removed from the test section and inserted in a section of idential A-nickel tubing. The tube was immersed in a constant-temperature water bath and the thermocouple head moved in the same manner as in the rod-bundle tests. For bath temperatures of 25, 50, 66 , and $82^{\circ} \mathrm{C}$ and 17 thermocouple locations, the maximum difference between the Hewlett-Packard DVM and Brown recorder readouts was $0.3^{\circ} \mathrm{C}$, and the maximum difference between the bath temperature and instrument indications was $0.5^{\circ} \mathrm{C}$. We conclude that the variability of wall temperature caused by thermocouple movement is negligible in terms of the inferred velocities, especially at the higher heat fluxes.

Fabrication is under way on a spool piece with a hexagonal crosssection Lucite insert for radial velocity-distribution tests, Teflon guide disks for the thermocouple-head extension tubes (to withstand higher wall temperatures), a spare A-nickel heater tube, anodized aluminum spacer wires for later local-boiling tests (in order to avoid premature burnout inducible by the nonwetting Teflon coating on the copper wire spacers presently in use), and a one-fifth-scale model of the Lucite shroud, which will be burst tested to determine the stress-concentration factor for the shroud configuration (rectangular exterior and hexagonal interior). If the stress factor is sufficiently small, the bundle will be pressurized to about 100 psig to attain larger nonboiling heat fluxes and film temperature differences. 


\subsection{FFM NOISE ANALYSIS}

(AEC Activity 046001091 )

$$
\text { D. N. Fry }
$$

The frequency spectra of temperature fluctuations on the inside of an LMFBR heater sheath were determined (these measurements were made in the single-heater-test facility). The objectives of this investigation were to determine (1) the degree of temperature fluctuation on the inside of the heater sheath and (2) whether noise analysis diagnostic methods can be used to detect thermocouple failures.

\section{Results and Conclusions}

A prototype of an LMFBR heater pin with five thermocouple elements (three Alumel and two Chromel) attached to the inside wall of the sheath is being tested in a single-heater sodium-cooled test loop. The temperature noise signals from two thermocouple combinations were analyzed and the results compared with the noise spectrum obtained from a similar thermocouple in a previous heater that had failed by touching the sheath at a point other than the intended hot junction. The frequency spectra of the two good thermocouples in the present test are similar, probably because they are located near each other. On the other hand, the temperature noise indicated by the good thermocouples is different than the noise from the failed thermocouple. (In Fig. 2.7 a representative spectrum from a good thermocouple is compared with that of the failed couple.) Moreover, the time response of the failed couple seems to be longer (lower break frequency). These differences in the nosie from good and bad thermocouples cannot be definitely attributed to the thermocouple failure, because the heater power was greater in the failed thermocouple test (a11 other test conditions were identica1). The relationship between heater power and temperature noise will be determined from tests now under way.

Figure 2.7 can be used to determine the actual rms temperature fluctuation as a function of frequency. For example, the good thermocouple indicated a mean temperature of approximately $1000^{\circ} \mathrm{F}$, and from Fig. 2.7 it may be seen that the temperature fluctuation on the inside of the 


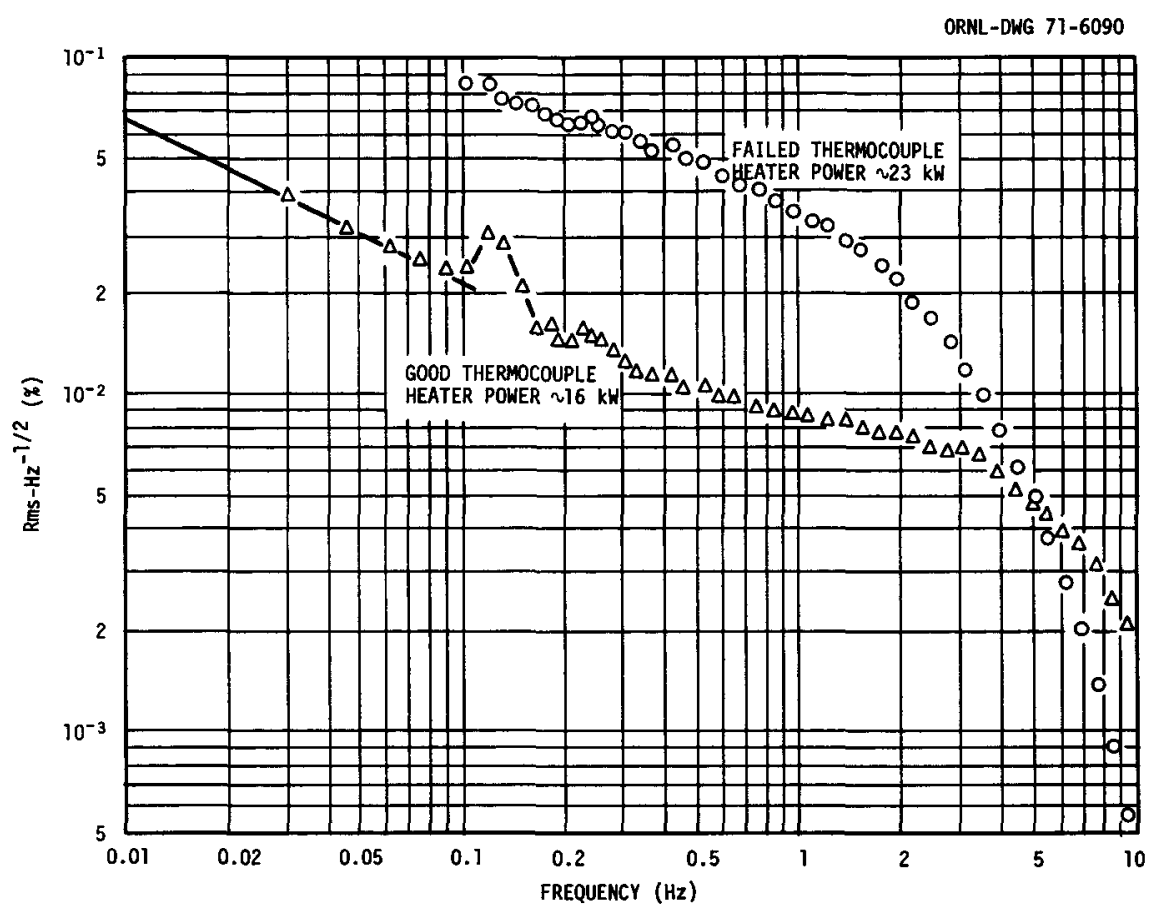

Fig. 2.7. Rms Noise Spectra of Temperature Fluctuations on the Inside Wall of a Heater Pin Sheath.

heater wall decreases from about $0.4 \mathrm{rms} \cdot{ }^{\circ} \mathrm{F}$ at $0.03 \mathrm{~Hz}$ to about $0.07 \mathrm{rms} \cdot{ }^{\circ} \mathrm{F}$ at $3 \mathrm{~Hz}$. No explanation can be given for the peak in temperature noise at $0.12 \mathrm{~Hz}$. It was present in a11 runs made during the second heater test. Temperature noise analysis may be useful for studying the dynamics of heat transfer from LMFBR heater pins. Previous measurements by Armistead indicate that the power spectral density (PSD) of the fluctuations in heat transfer induced by turbulent flow decreases with increasing frequency, and the shape of the frequency spectrum depends on the Reynolds number. ${ }^{1}$ He observed that the PSD varies approximately as frequency raised to the -0.90 power $\left(f^{-0.90}\right)$ at low frequencies. Figure 2.7 shows that the square root of the PSD of heater-wall temperature fluctuations varies as $f^{-0.48}\left(f^{-0.96}\right.$ for $\left.P S D\right)$ over the frequency range 0.03 to $0.5 \mathrm{~Hz}$. This indicates that the intrinsic thermocouple noise may be due to turbulenceinduced heat transfer variations. Although preliminary, this result suggests that temperature noise analysis may yield information about heat transfer and the degree of flow turbulence in the FFM. 


\section{Reference}

1. R. A. Armistead, Jr., Turbulence-Induced Heat-Transfer Fluctuations in Pipe Flow of Water Using Hot-Film Wall Sensors, USAEC Report ORNLTM-1602, Oak Ridge National Laboratory, Apri1 1967.

\subsection{FFM FACILITY ACTIVITIES \\ (AEC Activity 04600109 1) \\ D. L. Clark P. A. Gnadt \\ M. H. Fontana A. G. Grindell \\ R. E. MacPherson}

The FFM is a large high-temperature sodium-cooled facility in which 19 internally heated pins simulate LMFBR core segments. Following successful checkout of the facility with sodium, the first rod bundle (scalloped can with thermocouples only in the wire wrapping) was installed, and the test program is under way. Preparations for the fabrication of test bundle 2 are well under way. Work is continuing on installation of the datahandling system and noise analysis techniques for the facility.

\section{Bundle 1}

Final installation, preoperational testing, and acceptance of bundle 1, the protection equipment for unattended operation, and the modifications to the control system were completed. The piping and test section were filled with sodium, and data runs for tests 2 and 3 in test series $I$ are in progress. These tests will be continued until the fabrication of bundle 2 is completed.

Figures 2.8, 2.9, and 2.10 show bundle 1 just prior to installation in the facility. Attachment of the heaters to the tube sheet for bundle 1 was made by the electron-beam welding process at Electron Beam Welding, Inc., Los Angeles. The tube sheet was buttered with AISI type 308 stainless steel weld wire prior to final machining in an effort to enhance the ferritic structure to inhibit cracking in the weld area. The type 316 


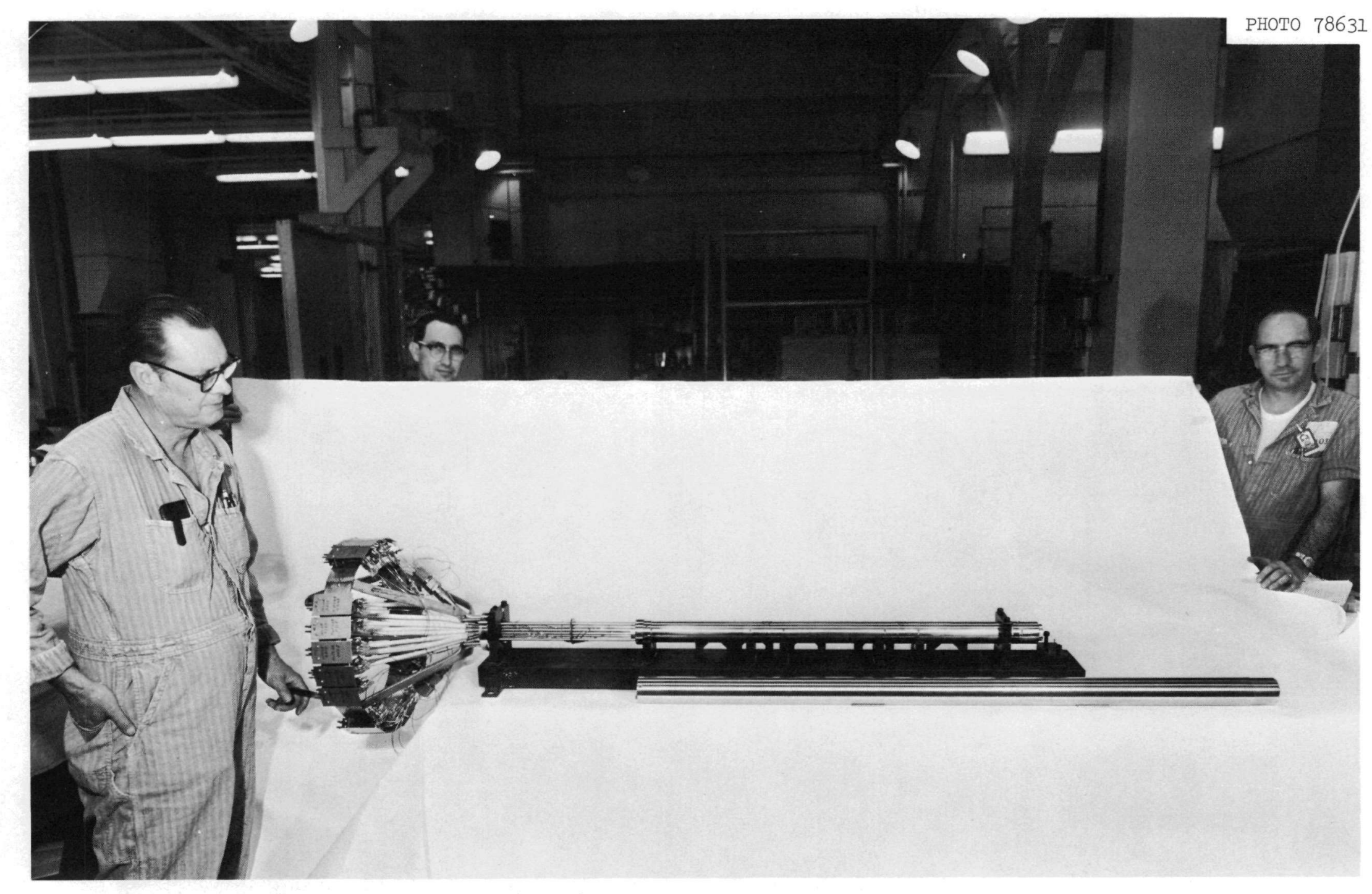

Fig. 2.8. Overall View of Bundle 1. 


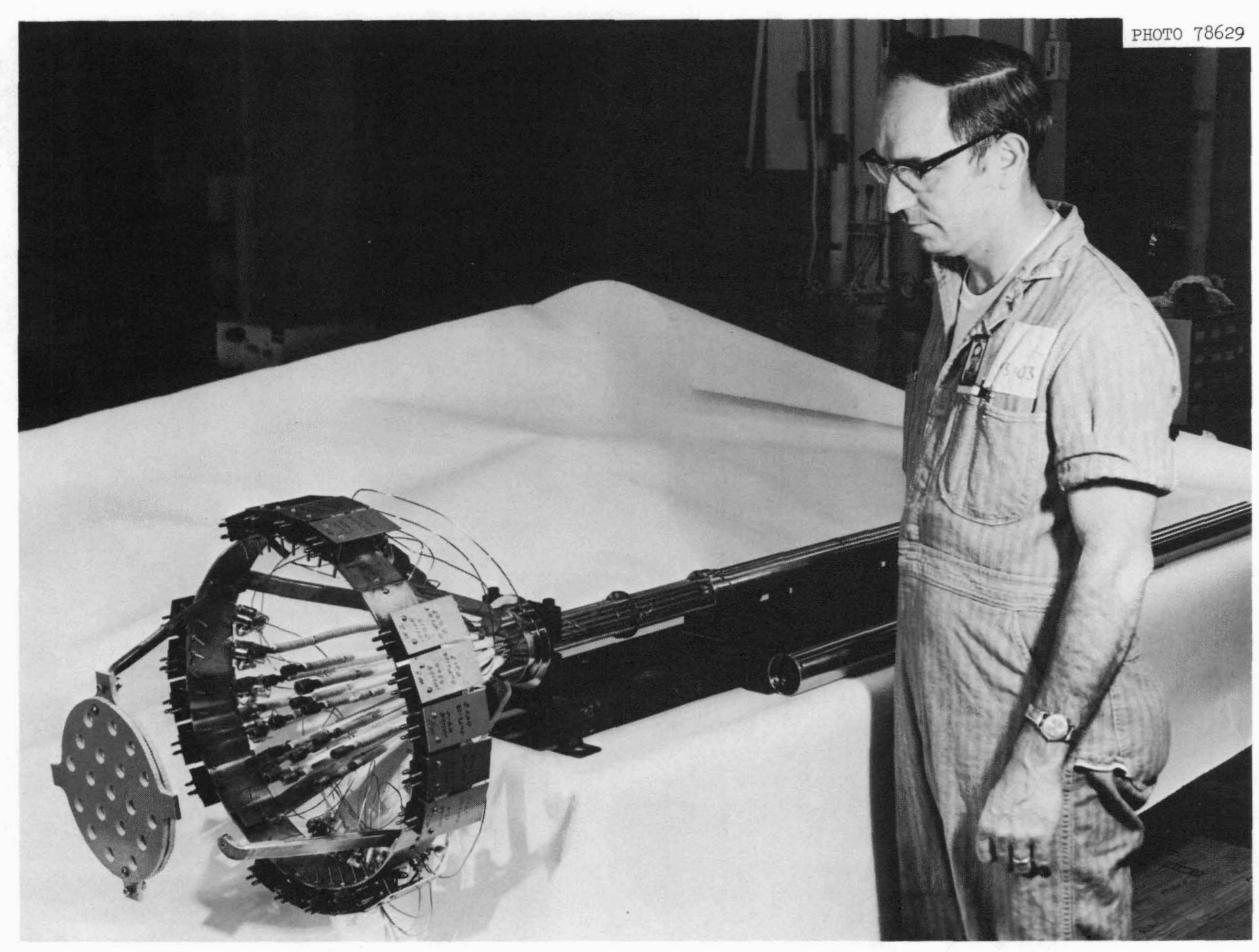

Fig. 2.9. Enlarged View of Bundle 1. 


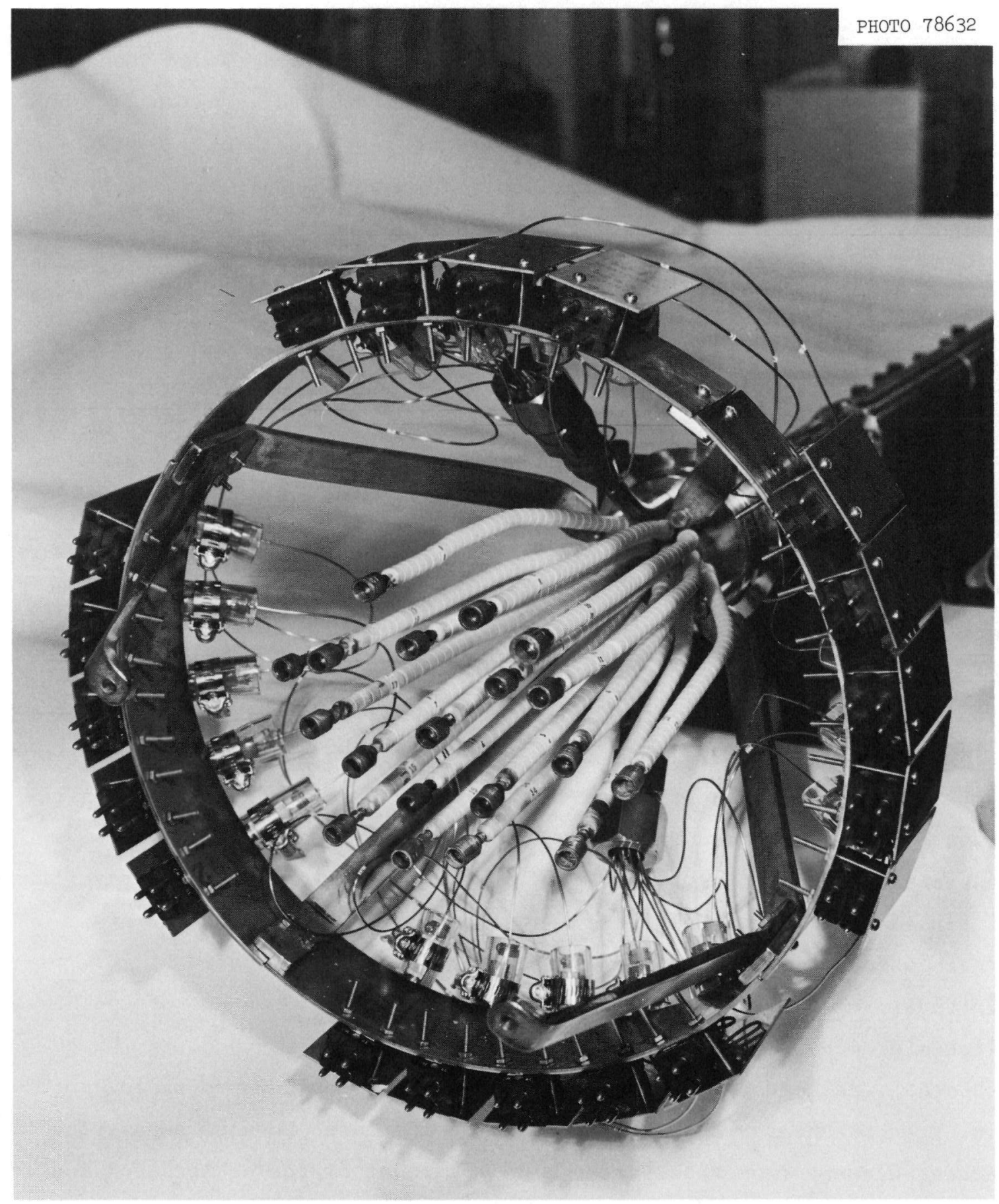

Fig. 2.10. End View of Bundle 1. 
stainless steel heater sheaths were welded to the type 308-buttered area. Pre- and postweld specimens were made, and examination showed that the welds had good penetration and ferritic structure and were sound. The bundle was subjected to a 690-psig pressure test and then to a helium leak test. These tests indicated that the tube sheet welds were satisfactory.

The facility operating manual was revised, and maintenance procedures are being prepared.

\section{Bundle 2}

Drawings for fabrication and assembly of bundle 2 were released to the shops and fabricators for cost estimating. Detailed design for the readout of the 105 bundle thermocouples will be started soon.

All but seven of the heaters and all thermocouples for bundle 2 are on hand. All quality-assurance inspections on the thermocouples were completed. Representative specimens of both grounded- and ungroundedjunction wire-wrapped thermocouples were subjected to thermal cycling from 500 to $1200^{\circ} \mathrm{F}$ for 250 cycles without failure. A $1000-\mathrm{hr}$ soak test at $1200^{\circ} \mathrm{F}$ of representative couples was completed, and the test indicated that both the grounded and ungrounded junction assemblies can survive the anticipated conditions. A portion of the heaters for bundle 2 have five internal thermocouple elements installed 18 or $19 \mathrm{in.}$ from the start of the heated zone. These five elements are bare wires spaced at $22.5^{\circ}$ intervals (e.g., the five elements are within a $90^{\circ}$ segment of the heater circumference) that are spot welded to the inner surface of the heater sheath. The lead extensions are mechanically spaced approximately 0.010 in. from the heater sheath within the BN-insulated annulus separating the heater element from the sheath. The remainder of the heaters for bundle 2 have three thermocouple elements but otherwise are identical to the five-thermocouple-element heaters.

All the heaters are being subjected to a number of special tests to qualify them for use in the FFM facility: neutron radiography, infrared temperature scans similar to those used at HEDL, liquid crystal examinations, and infrared photography with ASA 64 film. Quality-assurance 
inspections of 16 of the heaters were completed, and inspections of the remaining 14 are in progress.

An endurance test of a five-thermocouple-element heater at $9 \mathrm{~kW} / \mathrm{ft}$ (16 kW total) in $900^{\circ} \mathrm{F}$ sodium was started. On April 15, this heater had operated $46 \mathrm{hr}$ and been subjected to six thermal cycles. The heater is operated during the day and the loop operates isothermally overnight. The internal thermocouples of this heater are connected to a special dataaccumulation system for noise and other analyses.

\section{Instrumentation}

Final installation of the FFM data-handling system was completed and trial computer runs were made to establish the workability of the calculation and plotting programs.

The frequency spectrum of the noise signal from a spacer-wire (insulated-junction) thermocouple installed in the heater test facility was measured. The results indicate that the thermocouple time response is approximately $145 \mathrm{msec}$, which agrees with the 146- to 652-msec response obtained by inserting the thermocouples into boiling water. Larger holders for more sensitive hydrophones were fabricated and installed on the FFM test section. Development of an on-line acoustic noise monitor for the facility is continuing. Some tests were run on noise signals from the heater internal thermocouples; however, results of these tests are not yet available. 
-

. 
3. SPRAY AND PRESSURE-SUPPRESSION POOL TECHNOLOGY

\subsection{PROGRAM OBJECTIVES AND COORDINATION}

(AEC Activity $04 \quad 608001$ 1)

T. H. Row

The spray and pressure-suppression fission-product removal technology program was established to provide information needed to assess the efficiency of sprays and suppression pools as fission-product removal systems. Over the past four years, large-scale spray experiments and a number of support investigations of corrosion by spray solutions and the stability and chemical nature of spray solutions were completed.

The proceedings of a symposium presented in June 1970 at the Los Angeles ANS meeting were published as the April 1971 issue of Nuclear Technology, Vol. 10, No. 4.

Inasmuch as the program will be terminated at the end of this fiscal year, the major effort in all phases of the program is on final reporting of results. The suppression-pool work carried out by General Electric Company at San Jose was completed, and final reports are currently being reviewed. 


\subsection{NUCLEAR SAFETY PILOT PLANT}

(AEC Activity $04608001 \quad 1$ )

L. F. Parsly

Activity on this program is limited to preparation of reports. The report on particle removal was revised extensively, and the revised draft is being reviewed internally. The report covering the elemental iodine experiments was edited and is ready for typing in final form.

\subsection{RADIATION AND THERMAL STABILITY OF SPRAY SOLUTIONS \\ (AEC Activity 04608001 1) \\ H. E. Zittel}

The behavior of spray solutions under design-basis accident conditions is being examined. Studies of the hydrogen evolution from paint coatings were concluded, and additives for decreasing radiolytic hydrogen are being evaluated.

\section{Hydrogen Evolution from Paint Coatings}

The study of the evolution of $\mathrm{H}_{2}$ from the various types of coatings offered by vendors for reactor use was essentially completed. The data presented in Table 3.1, a continuation of data given in previous bimonthly reports, contains nothing surprising; they again illustrate that the presence of a top coat does little to stop $\mathrm{H}_{2}$ generation and, in many cases, may be said to enhance it. This is true even when a plastic is used, as may be seen. It should be stated that these studies have been little more than a scoping effort, and it is not intended that the data presented be taken as rigorous measures of these coatings under all conditions. It is evident that in order to obtain a comprehensive picture of the behavior of such coatings under accident conditions, a much more thorough study should be made. However, the data do show clearly that the zinc-containing primer coat is a potential source of fairly large amounts of $\mathrm{H}_{2}$ and that under design-basis accident conditions the presence of a topcoat does not necessarily eliminate this potential. 
Table 3.1. $\mathrm{H}_{2}$ Evolution from Coatings Under Design-Basis Accident Conditions

Test conditions: $5 \mathrm{~min}$ at $149^{\circ} \mathrm{C}$

$1 \mathrm{hr}$ and $45 \mathrm{~min}$ at $140^{\circ} \mathrm{C}$

$22 \mathrm{hr}$ and $15 \mathrm{~min}$ at $107^{\circ} \mathrm{C}$

Solution: $0.15 \mathrm{~N} \mathrm{NaOH}-3000 \mathrm{ppm} \mathrm{B}$

\begin{tabular}{|c|c|c|}
\hline Sample & Coating & $\begin{array}{l}\mathrm{H}_{2} \text { Yield } \\
\left(\mathrm{cc} / \mathrm{cm}^{2}\right)\end{array}$ \\
\hline $\mathrm{E}-1$ & 1.5-mil primer & 0.7 \\
\hline $\bar{E}-1-1$ & 1.5-mil primer + topcoat & 0.6 \\
\hline $\bar{E}-2$ & 2.0-mil primer & 0.8 \\
\hline$E-2-1$ & 2.0-mi1 primer + topcoat & 0.6 \\
\hline $\mathrm{E}-3$ & 3.5-mil primer & 1.3 \\
\hline$E-3-1$ & 3.5-mil primer + topcoat & 0.8 \\
\hline$E-4$ & 1.5-mil primer & 1.4 \\
\hline$E-4-1$ & 1.5-mil primer + topcoat (plastic) & 1.2 \\
\hline$E-5$ & 2.0-mil primer & 0.4 \\
\hline$E-5-1$ & 2.0-mil primer + topcoat (plastic) & 1.1 \\
\hline $\mathrm{E}-6$ & 3.5-mil primer & 0.9 \\
\hline $\mathrm{E}-6-1$ & 3.5-mil primer + topcoat (plastic) & 3.5 \\
\hline $\mathrm{F}-1$ & $1.5-\mathrm{mi} 1$ primer & 0.06 \\
\hline $\mathbf{F}-2$ & 2.0-mil primer & 0.09 \\
\hline F-3 & 3.5-mil primer & 0.2 \\
\hline$F-4$ & 1.5-mil primer & 0.7 \\
\hline F-4-1 & 1.5-mil primer + topcoat & 1.5 \\
\hline$F-5$ & 2.0-mil primer & 0.9 \\
\hline $\mathrm{F}-5-1$ & 2.0-mil primer + topcoat & 1.2 \\
\hline F-6 & 3.5-mil primer & 1.3 \\
\hline $\mathrm{F}-6-1$ & 3.5-mil primer + topcoat & 2.5 \\
\hline G-1 & 1.5-mil primer & 0.9 \\
\hline $\mathrm{G}-1-1^{a}$ & 1.5-mil primer + topcoat & 2.4 \\
\hline G-2 & 2.0-mil primer & 1.3 \\
\hline $\mathrm{G}-2-1^{a}$ & 2.0-mil primer + topcoat & 3.3 \\
\hline$G-3$ & 3.5-mil primer & 2.8 \\
\hline $\mathrm{G}-3-1^{a}$ & 3.5-mil primer + topcoat & 4.0 \\
\hline
\end{tabular}

$\underline{\text { Radiolytic } \mathrm{H}_{2}}$

The study of $\mathrm{NaVO}_{3}$ as a potential agent for decreasing radiolytic $\mathrm{H}_{2}$ was continued. Data obtained in the dynamic radiation loop facility on various spray solutions containing this agent are given in Table 3.2. 
Table 3.2. Effect of $\mathrm{NaVO}_{3}$ on Radiolytic $\mathrm{H}_{2}$ Generation

Test solutions:

(1) $0.15 \mathrm{~N} \mathrm{NaOH}-3000 \mathrm{ppm} \mathrm{B}$

(2) $0.15 \mathrm{~N} \mathrm{NaOH}-3000 \mathrm{ppm} \mathrm{B}, 2 \times 10^{-3} \mathrm{M} \mathrm{NaVO}_{3}$

(3) $3000 \mathrm{ppm} \mathrm{B}$

(4) $3000 \mathrm{ppm} \mathrm{B}, 2 \times 10^{-3} \mathrm{M} \mathrm{NaVO}_{3}$

Test facility: radiation loop

\begin{tabular}{cccc}
\hline $\begin{array}{c}\text { Radiation Dose } \\
\text { (rad) }\end{array}$ & Test Solution & $\begin{array}{c}\text { Temperature } \\
\left({ }^{\circ} \mathrm{C}\right)\end{array}$ & $\mathrm{G}\left(\mathrm{H}_{2}\right)$ \\
\hline $2 \times 10^{8}$ & 1 & 35 & 0.41 \\
& 2 & 35 & 0.03 \\
& 1 & 65 & 0.36 \\
& 2 & 65 & 0.04 \\
& 1 & 95 & 0.35 \\
$3 \times 10^{8}$ & 2 & 95 & 0.04 \\
& 1 & 125 & 0.30 \\
& 2 & 125 & 0.02 \\
& 3 & 65 & $36^{a}$ \\
& 4 & 65 & $3.2^{a}$ \\
& 3 & 95 & $28^{a}$ \\
& 4 & 95 & $2.5^{a}$ \\
\hline Values given in vol \% rather than $\mathrm{G}\left(\mathrm{H}_{2}\right)$ because they \\
were obtained at essentially steady state.
\end{tabular}

It may be seen that in the base-borate spray solution the $\mathrm{NaVO}_{3}$ decreases $\mathrm{G}\left(\mathrm{H}_{2}\right)$ by a factor of approximately 10 . This is in agreement with the results previously found in the static capsule tests. The results for the 3000-ppm-B solution also show that $\mathrm{NaVO}_{3}$ lowers the steady-state $\mathrm{H}_{2}$ concentration by approximately tenfold. It should be noted that the data for the two different spray solutions is not in the same terms because the $\mathrm{H}_{2}$ data for the $3000-\mathrm{ppm}-\mathrm{B}$ system were obtained after the rate of gas pressure increase reached essentially zero. For the base-borate system the data were obtained after a given dose while the gas pressure was still increasing. 


\subsection{SCALE-MODEL TESTS OF FISSION-PRODUCT REMOVAL IN SUPPRESSION POOLS}

(AEC Activity 04608001 1)

D. P. Siegwarth M. Siegler

A 1/10,000-scale model of a pressure-suppression pool was used for tests to study the absorption of fission products in the pool under simulated loss-of-coolant accident conditions.

The tests were conducted in two phases, and the results of the first phase are discussed in Ref. 1. Subsequent to the completion of this work, the scope and completion date of the subcontract were extended to include the following additional work:

1. measure the effect of sodium metavanadate on the absorption of methyl iodide in the scale-model suppression pool,

2. evaluate the ability of the suppression pool to absorb methyl iodide released to the containment vessel after completion of blowdown.

The second-phase experimental work was completed, and the data are being analyzed. They will be presented in a final report.

\section{Reference}

1. D. P. Siegwarth and M. Siegler, Scale-Model Tests of Fission Product Removal in Suppression Pools, USAEC Report GEAP-13172, General Electric Company (in press). 
$\bullet$

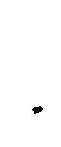


4. SAFETY STUDIES OF THE HTGR

H. J. de Nordwall, Coordinator

\subsection{STUDIES OF REACTIONS OF GRAPHITE WITH STEAM \\ (AEC Activity $0460 \quad 1001 \quad 1$ ) \\ C. M. Blood \\ S. H. Freid \\ H. J, de Nordwall* \\ A. P. Malinauskas* \\ H. Montgomery}

The reactions of steam with various graphites are being studied to develop methods for calculating the effects of steam on the core of an HTGR and the rates of hydrogen and carbon monoxide production.

Laboratory investigations are centered on the determination of rate constants and the understanding of reasons why the observed rate of reaction varies with the extent of reaction. The in-pile program is devoted to testing the validity of the synthesis of laboratory data under realistic conditions.

\section{Laboratory Investigations}

Steam-graphite reaction studies at 800,900 , and $1000^{\circ} \mathrm{C}$ were continued, and the data obtained at $1000^{\circ} \mathrm{C}$ are presented in Tables 4.1 and 4.2. Table 4.1 lists amounts of graphite removed from samples as a function of duration of exposure to a flowing helium-steam mixture. The data were reduced to correspond to conditions of $0.0950-$ atm partial-pressure 
Table 4.1. Reaction of 11.5619-g H-327 Graphite Specimen with $0.0950-\mathrm{atm}$ Steam at $1000^{\circ} \mathrm{C}$

\begin{tabular}{cccc}
\hline $\begin{array}{c}\text { Steam } \\
\text { Exposure } \\
\text { Time } \\
\text { (min) }\end{array}$ & $\begin{array}{c}\text { Graphite } \\
\text { Removed } \\
\text { (mg) }\end{array}$ & $\begin{array}{c}\text { Apparent } \\
\text { Reaction } \\
\text { Rate } \\
\text { (mg/min) }\end{array}$ & $\begin{array}{c}\text { Burnoff } a \\
(\%)\end{array}$ \\
\hline 25 & 37.7 & 1.57 & 0.33 \\
57 & 89.6 & 1.53 & 0.77 \\
92 & 139.9 & 1.81 & 1.21 \\
132 & 225.3 & 2.14 & 1.95 \\
172 & 310.9 & 2.17 & 2.69 \\
232 & 441.9 & 2.35 & 3.82 \\
297 & 604.6 & 2.63 & 5.23 \\
357 & 770.5 & 2.90 & 6.66 \\
417 & 952.5 & 3.16 & 8.24 \\
477 & 1149.3 & 3.55 & 9.94 \\
537 & 1378.1 & & 11.92 \\
\hline \multicolumn{4}{c}{ Adjusted for variations in steam partial } \\
pressure and in temperature.
\end{tabular}

Table 4.2. Alterations in Geometrical Features of H-327 Graphite Sample Upon Exposure to Steam

\begin{tabular}{|c|c|c|c|c|}
\hline $\begin{array}{l}\text { Steam } \\
\text { Exposure } \\
\text { Time } \\
\text { (min) }\end{array}$ & $\begin{array}{c}\text { Knudsen Diffusion } \\
\text { Coefficient } \\
\text { for Helium } \\
\left(\mathrm{cm}^{2} / \mathrm{sec}\right)\end{array}$ & $\begin{array}{c}\text { Viscous } \\
\text { Flow } \\
\text { Coefficient } \\
\left(\mathrm{cm}^{2} / \mathrm{atm} \cdot \mathrm{sec}\right)\end{array}$ & $\begin{array}{l}\text { Porosity- } \\
\text { Tortuosity } \\
\text { Ratio }\end{array}$ & $\begin{array}{l}\text { BET } \\
\text { Surface } \\
\text { Area } \\
\left(\mathrm{m}^{2}\right)\end{array}$ \\
\hline 0 & 1.09 & 7.76 & $4.03 \times 10^{-3}$ & 2.20 \\
\hline 25 & 1.06 & 9.90 & $4.54 \times 10^{-3}$ & 5.20 \\
\hline 57 & & & & 7.35 \\
\hline 92 & 1.04 & 10.36 & $6.06 \times 10^{-3}$ & 9.96 \\
\hline 132 & & & & 13.75 \\
\hline 172 & 0.97 & 11.04 & $8.07 \times 10^{-3}$ & 16.36 \\
\hline 232 & & & & 22.20 \\
\hline 297 & 1.13 & 11.44 & $10.19 \times 10^{-3}$ & 26.62 \\
\hline 357 & & & & 31.31 \\
\hline 417 & 1.25 & 12.37 & $15.23 \times 10^{-3}$ & 34.19 \\
\hline 477 & & & & 38.65 \\
\hline 537 & $(a)$ & $(a)$ & $(a)$ & 40.61 \\
\hline
\end{tabular}

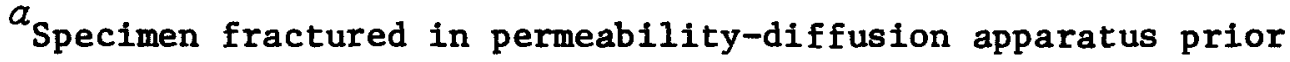
to experiment. 
steam and $1000^{\circ} \mathrm{C}$. The corrections required to perform the adjustments for variations in steam partial pressure and in temperature were made under the assumptions that the rate of reaction varies linearly with steam concentration and that the temperature dependence corresponds to an activation energy of $60 \mathrm{kcal} / \mathrm{mole}$. As may be seen from the results, the apparent rate of reaction undergoes an approximate twofold increase over about a $10 \%$ range of burnoff. Attendant changes in geometry are described in Table 4.2.

The Knudsen diffusion and modified viscous flow coefficients given in Table 4.2 were determined with helium, whereas the surface areas were measured in accordance with the standard nitrogen BET procedure. Transport of the gas through the graphite is characterized almost completely in hydrodynamic terms, rather than as movement of free molecules. Partly for this reason the results given for the Knudsen diffusion coefficient with helium are not sufficiently accurate to serve as a reliable indicator of geometric changes. The remaining parameters, however, reflect an unmistakable increase in characteristic pore size. Thus the viscous flow coefficient increases about twofold over the burnoff range investigated, whereas the porosity-tortuosity ratio undergoes an approximate threefold increase. The surface area, on the other hand, undergoes an even more dramatic change - in the present case it increased almost by a factor of 20. No detectable change in external geometry of the specimen was noted; this, as well as the magnitude of the change in surface area, renders obvious the fact that considerable steam attack occurred within the body of the specimen.

After the specimen had been exposed to steam $534 \mathrm{~min}$, it was structurally weak. This was not obvious by visual examination, but the sample crumbled when installed in the permeability-diffusion apparatus. In terms of real (i.e., not adjusted) burnoff, this structural weakening occurred when there had been $91 / 2$ and $11 \%$ burnoff of the specimen.

\section{In-Pile Experiments}

The second in-pile experiment, SG-2, was performed to study oxidation by steam of an $\mathrm{H}-327$ graphite casing on fuel having a low surface 
temperature. There were two significant differences between this experiment and experiment SG-1.' The graphite casing surrounding the fuel in the first experiment, although nominally $\mathrm{H}-327$, contained iron and exhibited severe pitting-type corrosion. For experiment SG-2, as will be the case for all subsequent experiments, a purer H-327 graphite was used that did not exhibit pitting corrosion. Also the binder composition of the fuel stick was changed. In experiment SG-1 it was varcum and carbon black, while in experiment SG-2 it was pitch and approximately 25 wt \% carbon black. This latter formulation gives a much stronger fuel pellet, and it will be used in future experiments; however, there appears to be a significant difference in the thermal conductivity of the two types of fuel pellet. The irradiation history of experiment SG-2 is given in Table 4.3. The experiment capsule has been disassembled in the hot cells, and data analysis is in progress. Some preliminary conclusions can be drawn: (1) gas release was moderate, indicating somewhat less than $1 \%$ broken fuel particles; (2) no pitting corrosion was observed in the graphite can, as expected, but the total oxidation was exceptionally small; (3) the fuel pellet was mostly intact but did show evidence of steam penetration around the center-line thermocouple; and (4) there are indications of significant tritium production. An attempt is being made to locate the source of the tritium, which may be unrelated to the fuel or the carbonaceous components of the experiment.

Table 4.3. Irradiation History of HTGR Experiment SG-2

\begin{tabular}{cccc}
\hline $\begin{array}{c}\text { Experiment } \\
\text { Duration } \\
(\mathrm{hr})\end{array}$ & $\begin{array}{c}\text { Graphite } \\
\text { Temperature } \\
\left({ }^{\circ} \mathrm{C}\right)\end{array}$ & $\begin{array}{c}\text { Fuel } \\
\text { Center-Line } \\
\text { Temperature } \\
\left({ }^{\circ} \mathrm{C}\right)\end{array}$ & $\begin{array}{c}\text { Atmosphere } \\
\text { (mole fraction } \\
\mathrm{H}_{2} \text { O) }\end{array}$ \\
\hline 146 & 700 & 1060 & 0 \\
3.1 & 700 & 1060 & 0.03 \\
2.4 & 750 & 1190 & 0.03 \\
0.3 & 788 & 1240 & 0.03 \\
\hline
\end{tabular}




\section{$\underline{\text { Reference }}$}

1. C. M. Blood et al., Studies of Reactions of Graphite with Steam, pp. 54-59, ORNL Nuclear Safety Research and Development Program Bimonthly Report for September-October 1970, USAEC Report ORNL-TM-3212, Oak Ridge National Laboratory, 1971.

\subsection{FUEL INTEGRITY AND FISSION-PRODUCT RELEASE}

(AEC Activity $04601001 \quad 1$ )

$$
\text { M. T. Morgan R. L. Towns }
$$

C. D. Baumann

Fuel particle coating failures that occur when temperatures and temperature gradients exceed those to be expected during normal operations are being investigated. Knowledge of when a fuel element is likely to fail after a perturbation is necessary for the design of engineered safety features and proper analysis of risks involved from fission-product release. Quantitative determinations are being made of fission-product release from coated fuel particles in bonded beds during postirradiation annealing.

\section{Cesium and Strontium Release from Bonded Beds}

Bonded bed B-21 from the B9-42 capsule has accumulated $850 \mathrm{hr}$ of postirradiation annealing time at $1250^{\circ} \mathrm{C}$. This bonded bed contains Bisocoated $\mathrm{UO}_{2}$ particles irradiated to $10 \%$ FIMA.

Cesium release at $550 \mathrm{hr}$ was negligible. This indicated a lower diffusion coefficient for cesium in pyrolytic carbon than that calculated from the B-46 and B-51 bonded bed data. Particles from these beds began to release cesium during postirradiation annealing at about $400 \mathrm{hr}$. The B-46 and B-51 bonded beds were identical with the B-21 bed, except that they were irradiated to $20 \%$ FIMA in capsule B9-41. Individual coated particles from the $B 9-41$ and $B 9-42$ capsules with burnups of $20 \%$ and $10 \%$ FIMA, respectively, will be annealed in the multiple-tube crucible for a more direct comparison. 


\section{Diffusion of Cesium in Pyrolytic-Carbon Coatings}

Coated particles from batches $1 \mathrm{~T} 1$ and $1 \mathrm{~B} 4$, 1rradiated to $4 \times 10^{21}$ neutrons $/ \mathrm{cm}^{2}$ fast fluence in experiment HT-1 in the HFIR reactor, are being annealed in the multiple-tube crucible at $1400^{\circ} \mathrm{C}$. Beta activity was released during the first few hours of annealing. The gamma spectra show the presence of a small amount of europium, but little of any other gammaemitting fission products; therefore we believe the brehmsstrahlung emission will be approximately proportional to the ${ }^{90} \mathrm{Sr}$, which is the main source of beta activity. Diffusion coefficients calculated from the time taken for the beta emitters to pass through the coatings at $1400^{\circ} \mathrm{C}$ were approximately $4 \times 10^{-9} \mathrm{~cm}^{2} / \mathrm{sec}$ for the low-temperature-isotropic pyrolyticcarbon-coated particles from batch 1 T1 and approximately $9 \times 10^{-10} \mathrm{~cm}^{2} / \mathrm{sec}$ for the high-temperature-isotropic pyrolytic-carbon-coated particles from batch 1B4. These values may be in error by as much as a factor of 4, since the data points are scattered, but they give a strong indication of a difference between the two types of coated particles.

Cesium had just begun to emerge from both groups of coated particles at an annealing time of $86 \mathrm{hr}$. A second group of coated particles from batches $1 \mathrm{~T} 3$ and $1 \mathrm{~B} 6$ is now being annealed at $1400^{\circ} \mathrm{C}$. Like those from batch 1B4, these coated particles were irradiated in the HT-1 experiment.

\subsection{FISSION PRODUCTS IN HTGR COOLANT CIRCUITS}

(AEC Activity $04601001 \quad 1$ )
F. F. Dyer*
H. J. de Nordwa11*
J. 0. Kolb
E. Hoinkis**

Efforts are under way to describe and explain the distribution and adhesion of fission products in the coolant circuits of HTGRs. As part

\footnotetext{
*Part time.

**Visiting Scientist from Hahn Meitner Institute, Berlin.
} 
of this effort, gas samplers are being installed in the Peach Bottom HTGR primary gas circuit for fission-product surveillance.

\section{$\underline{\text { Dust Dynamics }}$}

Development of tagged aerosol generation and equipment modification were continued in preparation for dust transport experiments in a straight channel with turbulently flowing air. The system for conducting these experiments was previously described. ${ }^{1}$

Trial dopings with $\mathrm{CrCl}_{3}$ solutions on 1/8-in.-diam ATJ graphite rods were performed to develop a technique for tagging the graphite aerosol with ${ }^{51} \mathrm{Cr}$. Adequate concentrations of ${ }^{51} \mathrm{Cr}$ could be obtained, but uniformity of the specific activity remains to be demonstrated.

\section{Fission-Product Surveillance Program}

Preparations are being made to install two gas samplers at the Peach Bottom HTGR and to make a gamma-activity survey of the No. 1 primary loop. Agreement was reached with the Peach Bottom Operational Safety Committee and the Philadelphia Electric Company with regard to equipment and procedures.

\section{Reference}

1. F. F. Dyer, E. Hoinkis, J. O. Kolb, and H. J. de Nordwa11, Fission Products in HTGR Coolant Circuits, pp. 66-70, ORNL Nuclear Safety Research and Development Program Bimonthly Report for July-August 1970, USAEC Report ORNL-TM-3122, Oak Ridge National Laboratory. 
-

.

.

. 
5. PRESSURE VESSEL AND PIPING TECHNOLOGY

\author{
5.1 HEAVY-SECTION STEEL TECHNOLOGY PROGRAM \\ (AEC Activity 046080031 ) \\ F. J. Witt
}

\begin{abstract}
Catastrophic failure of a reactor vessel in service cannot be tolerated under any circumstances, and less dramatic fractures would affect the economics of the service life of a nuclear reactor. The Heavy-Section Steel Technology (HSST) program is one of the major engineering safety research programs sponsored by the USAEC for assessing the fracture potential and margins of safety of reactor vessels that possibly contain flaws or inhomogeneities under in-service startup, operating, and cooldown conditions. The research obfectives of the HSST program are being met by performing critical tests on specimens up to 12 in. thick and pressure vessels up to 6 in. thick.

The research efforts of the HSST program are being carried out under 12 tasks. Three of the tasks have been completed, and the remaining tasks are discussed below.
\end{abstract}

\title{
Task A - Program Administration and Procurement
}

The Fifth Annual Information Meeting of the HSST Program was held at Oak Ridge National Laboratory on March 25 and 26, 1971. Thirty-one papers were presented and 27 preprints were avallable. There were 118 visitors, including 16 foreign visitors representing elght forelgn 
countries. The banquet was highlighted by a presentation by Norman Bessac of Carolina Power and Light Company on the "Future of Nuclear Power."

One technical report, ${ }^{1}$ one progress report, ${ }^{2}$ and one technical manuscript ${ }^{3}$ were distributed. Three reports were reviewed for publication. The eighth semiannual progress report is being collated. Three subcontracts were extended. One purchase order was negotiated.

Task B - Material Inspection and Contro1

Fabrication of the intermediate test vessels continues to be monitored. Inspection was also provided for fabrication of a 6-in. weld to be used in the irradiation program.

Task D - Variability in Plates, Heat-Affected Zones, Welds, and Forgings

Machining of specimens from some regions of HSST plates not previously investigated is in progress. The final mechanical property and metallurgical investigations of the intermediate test vessel forging material were completed. The results further verified those reported previous $1 \mathrm{y} \cdot{ }^{4}$

\section{Task F - Fracture Mechanics Investigations}

Subcontracts were extended with Brown University for developing the elastic-plastic three-dimensional stress and strain analysis computer program, with TRW Systems, Inc., for investigating the gross strain crack tolerance of steels and with Materials Research Laboratory for completing the crack-arrest toughness investigations. Technical reports are being prepared on each of these investigations.

The dynamic fracture toughness investigations were concluded, and a final report is being published. A summary of the static and dynamic fracture toughness investigations is given in Fig. 5.1. The results were collated by Mager ${ }^{5}$ of Westinghouse Electric Corporation. Results are presented for both plate and weld metal in unirradiated and irradiated condition. The dashed-line extensions are best estimates of the curves 


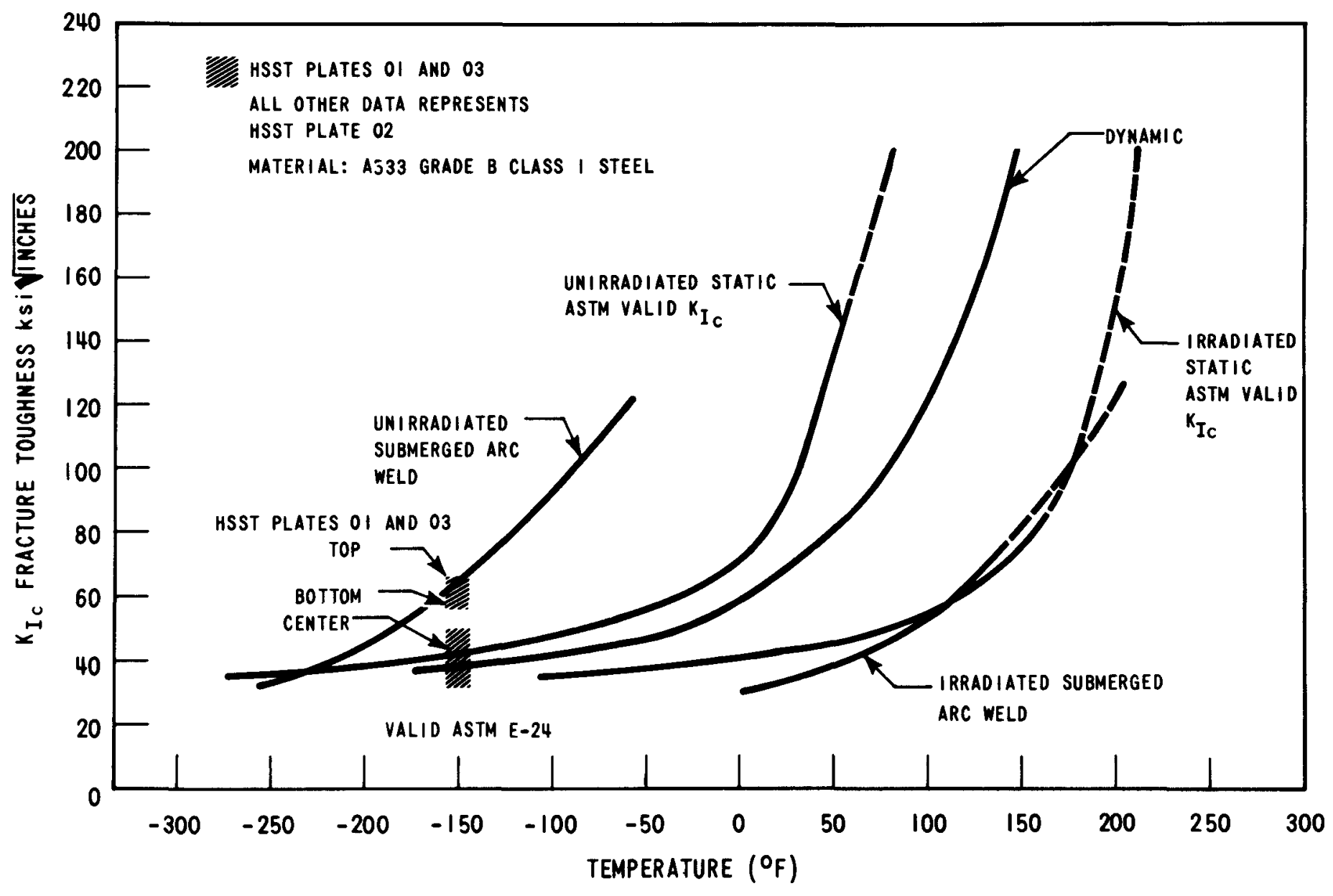

Fig. 5.1. Summary of Irradiated and Unirradiated Fracture Toughness Properties of HSST Steel Plate and Weldment. Dashed line extensions are extrapolations based on the best available information. (Westinghouse Electric Corporation drawing) 
based on available information. The irradiation results are for fluences of about $5 \times 10^{19}$ neutrons $/ \mathrm{cm}^{2}$ (E $>1 \mathrm{MeV}$ ) for irradiations at $550^{\circ} \mathrm{F}$. While high toughness levels are indicated by the lines the levels of toughness above $80,000 \mathrm{psi} \cdot \sqrt{\mathrm{in}}$. for the irradiated material have yet to be verified.

\section{Task G - Fatigue and Crack Propagation}

The investigation of crack growth rates as a function of stress intensity in the in-service environment (excluding irradiation) was completed by Westinghouse Electric Corporation, and a final report is being prepared. Typical results are shown in Fig. 5.2. The major conclusion

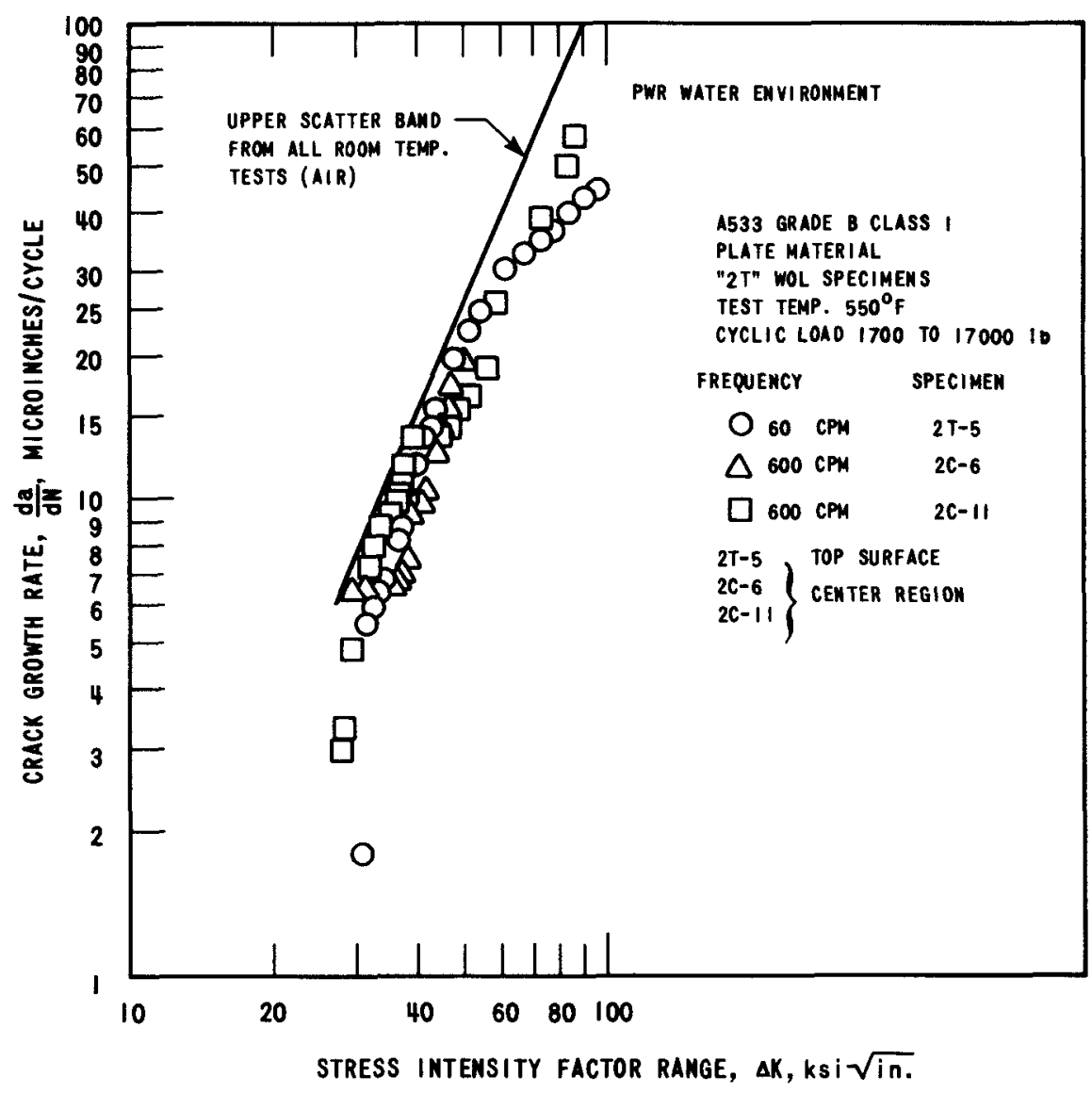

Fig. 5.2 Crack Growth Rate as a Function of Stress Intensity for A 533, Grade B, Class 1 Steel Plate in Pressurized-Water Reactor Environment. (Westinghouse Electric Corporation drawing) 
of this study is that the presence of a nuclear-reactor-grade water environment (chemistry and pressure) for pressurized-water and boilingwater reactors does not have an effect on the fatigue crack growth of ASTM, A 533, grade B, class 1 steel plate and weldments. ${ }^{6}$

\section{$\underline{\text { Task } \mathrm{H} \text { - Irradiation Effects }}$}

The gamma-heating investigation of a $4 \mathrm{~T}$ (4-in.-thick) compact tension specimen in the Experimental Test Reactor (ETR) was completed by Hanford Engineering Development Laboratory, and the results are being evaluated. Preparation for a similar investigation in the Babcock and Wilcox Test Reactor (BAWTR) by Westinghouse Electric Corporation is under way.

\section{Task I - Complex Stress State}

Nine small cylindrical pressure vessels fabricated from HSST plate 01 steel and containing sharp flaws were tested. The pressure versus strain curves are shown in Fig. 5.3. The strain is the circumferential strain in the cylindrical test section away from the flaws. The 3-in.diam vessels were $0.44 \mathrm{in}$. thick and contained flaws $0.15 \mathrm{in}$. deep, while the 6-in.-diam vessels were 0.88 in. thick and contained flaws 0.30 in.

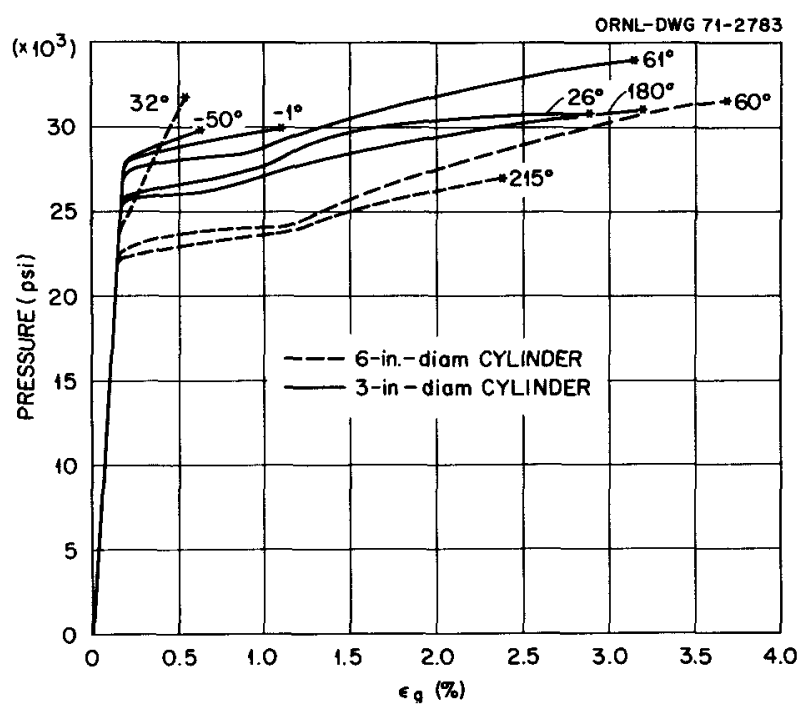

Fig. 5.3. Pressure-Strain Curves for Six Flawed 3-in.-OD Pressure Vessels 0.44 in. Thick and Three Flawed 6-in.-OD Vessels 0.88 in. Thick. 
deep. The transition to higher toughness levels is between -1 and $26^{\circ} \mathrm{F}$ for the 3-in.-diam vessels and between 32 and $60^{\circ} \mathrm{F}$ for the 6-in.-diam vessels. Six 1-in.-thick vessels are scheduled for welding and will be tested soon after fabrication is completed.

\section{$\underline{\text { Task K - Simulated Service Test }}$}

Ten 6-in.-thick flawed tensile specimens have now been tested, and the results have been discussed in progress reports. The data from these ten tests are summarized in Table 5.1 and may be associated with the correspondingly numbered fracture surfaces shown in Fig. 5.4. Three 6-in. weld specimens are being fabricated.

Fabrication of the six 6-in.-thick intermediate test vessels is continuing, with delivery of the first vessel now scheduled for late June.

\section{Task L - Specific Safety Research}

Final reports of the correlation study of fracture toughness with Charpy impact energy and the thermal shock investigation (emergency corecooling accident) are being prepared.

A preliminary investigation of certain aspects of fracture toughness as related to Charpy impact energy is being initiated.

\section{References}

1. N. Levy and P. V. Marcal, Three-Dimensional Elastic-Plastic Stress and Strain Analysis for Fracture Mechanics, Phase 1: Simple Flawed Specimens, Report No. HSSTP-TR-12, Brown University, December 1970.

2. F. J. Witt, Heavy-Section Steel Technology Program Semiannual Progress Report for Period Ending August 31, 1970, USAEC Report ORNL-4653, Oak Ridge National Laboratory, April 1971.

3. C. E. Childress, Manual for ASTM A 533 Grade B Class 1 Steel (HSST Plate 03) Provided to the International Atomic Energy Agency, USAEC Report ORNL-TM-3193, Oak Ridge National Laboratory, March 1971.

4. F. J. Witt, Heavy-Section Steel Technology Program, pp. 79-100, ORNL Nuclear Safety Research and Development Program Bimonthly Report for January-February 1971, USAEC Report ORNL-TM-3342, Oak Ridge National Laboratory, May 1971. 
Table 5.1. Tensile Test Data for 6-1n.-Thick Flawed Tensile Specimens

\begin{tabular}{|c|c|c|c|c|c|c|c|c|c|c|c|c|c|c|c|}
\hline \multirow{2}{*}{$\begin{array}{l}\text { Specimen } \\
\text { No. }\end{array}$} & \multirow{2}{*}{$\begin{array}{c}\text { Test } \\
\text { Temperature } \\
\left({ }^{\circ} \mathrm{F}\right)\end{array}$} & \multirow{2}{*}{$\begin{array}{l}\text { HSST } \\
\text { P1ate } \\
\text { No. }\end{array}$} & \multirow{2}{*}{$\begin{array}{l}\text { Gage } \\
\text { Length } \\
\text { (in.) }\end{array}$} & \multirow{2}{*}{$\begin{array}{l}\text { Width } \\
\text { (in.) }\end{array}$} & \multirow{2}{*}{$\begin{array}{l}\text { Thickness } \\
\text { (in.) }\end{array}$} & \multirow{2}{*}{$\begin{array}{c}\text { Gross } \\
\text { Area } \\
\left(1 .^{2}\right)\end{array}$} & \multirow{2}{*}{$\begin{array}{l}\text { Net } \\
\text { Area } \\
\text { (in. }{ }^{2} \text { ) }\end{array}$} & \multirow{2}{*}{$\begin{array}{l}\text { Elastic } \\
\text { Limit } \\
\text { Load } \\
\text { (kips) }\end{array}$} & \multicolumn{2}{|c|}{$\begin{array}{r}\text { Elastic Limit } \\
\text { Stress }(\mathbf{k s i})\end{array}$} & \multirow{2}{*}{$\begin{array}{l}\text { U1timate } \\
\text { Load } \\
\text { (kips) }\end{array}$} & \multicolumn{2}{|c|}{$\begin{array}{c}\text { U1timate Stress } \\
\text { (ksi) }\end{array}$} & \multirow{2}{*}{$\begin{array}{c}\text { Average } \\
\text { Strain at } \\
\text { U1timate } \\
\text { Stress } \\
(\%)\end{array}$} & \multirow{2}{*}{$\begin{array}{c}\text { Average } \\
\text { Strain at } \\
\text { Fracture } \\
(\%)\end{array}$} \\
\hline & & & & & & & & & $\begin{array}{l}\text { Gross } \\
\text { Section }\end{array}$ & $\begin{array}{c}\text { Net } \\
\text { Section }\end{array}$ & & $\begin{array}{l}\text { Gross } \\
\text { Section }\end{array}$ & $\begin{array}{c}\text { Net } \\
\text { Section }\end{array}$ & & \\
\hline \multicolumn{16}{|c|}{ Longitudinal Specimens } \\
\hline $\begin{array}{l}1 \\
2 \\
3 \\
4 \\
5 \\
6 \\
7\end{array}$ & $\begin{array}{r}215 \\
220 \\
50 \\
100 \\
75 \\
100 \\
100\end{array}$ & $\begin{array}{l}03 \\
03 \\
01 \\
01 \\
01 \\
01 \\
03\end{array}$ & $\begin{array}{l}24 \\
24 \\
24 \\
24 \\
24 \\
24 \\
24\end{array}$ & $\begin{array}{l}18 \\
18 \\
18 \\
18 \\
18 \\
18 \\
18\end{array}$ & $\begin{array}{l}6 \\
6 \\
6 \\
6 \\
6 \\
6 \\
6\end{array}$ & $\begin{array}{l}108 \\
108 \\
108 \\
108 \\
108 \\
108 \\
108\end{array}$ & $\begin{array}{l}95.69 \\
97.82 \\
95.79 \\
95.50 \\
92.33 \\
81.97 \\
92.43\end{array}$ & $\begin{array}{l}5720 \\
6000 \\
4400 \\
6000 \\
5500 \\
4000 \\
6500\end{array}$ & $\begin{array}{l}54.0 \\
55.5 \\
40.7 \\
55.5 \\
50.9 \\
37.0 \\
60.2\end{array}$ & $\begin{array}{l}59.8 \\
61.2 \\
46.0 \\
62.8 \\
59.7 \\
48.8 \\
70.4\end{array}$ & $\begin{array}{l}7300 \\
7550 \\
5300 \\
7500 \\
5900 \\
4700 \\
7050\end{array}$ & $\begin{array}{l}67.5 \\
69.9 \\
49.1 \\
69.4 \\
54.6 \\
43.5 \\
65.2\end{array}$ & $\begin{array}{l}76.3 \\
77.2 \\
55.4 \\
78.5 \\
63.9 \\
57.4 \\
76.2\end{array}$ & $\begin{array}{l}3.83 \\
0.24 \\
4.10 \\
0.35 \\
0.48 \\
0.88\end{array}$ & $\begin{array}{l}8.50 \\
9.60 \\
0.24 \\
7.90 \\
0.35 \\
0.48 \\
0.88\end{array}$ \\
\hline \multicolumn{16}{|c|}{ Transverse Specimens } \\
\hline $\begin{array}{r}8 \\
9 \\
10\end{array}$ & $\begin{array}{l}100 \\
220 \\
130\end{array}$ & $\begin{array}{l}03 \\
03 \\
03\end{array}$ & $\begin{array}{l}24 \\
24 \\
24\end{array}$ & $\begin{array}{l}18 \\
18 \\
18\end{array}$ & $\begin{array}{l}6 \\
6 \\
6\end{array}$ & $\begin{array}{l}108 \\
108 \\
108\end{array}$ & $\begin{array}{l}92.55 \\
93.30 \\
93.15\end{array}$ & $\begin{array}{l}6400 \\
5000 \\
6200\end{array}$ & $\begin{array}{l}59.4 \\
46.4 \\
57.4\end{array}$ & $\begin{array}{l}69.4 \\
54.1 \\
66.5\end{array}$ & $\begin{array}{l}6800 \\
6675 \\
6650\end{array}$ & $\begin{array}{l}63.0 \\
61.8 \\
61.6\end{array}$ & $\begin{array}{l}73.5 \\
71.6 \\
71.4\end{array}$ & $\begin{array}{l}0.74 \\
2.00 \\
1.19\end{array}$ & $\begin{array}{l}0.74 \\
3.60 \\
2.69\end{array}$ \\
\hline
\end{tabular}




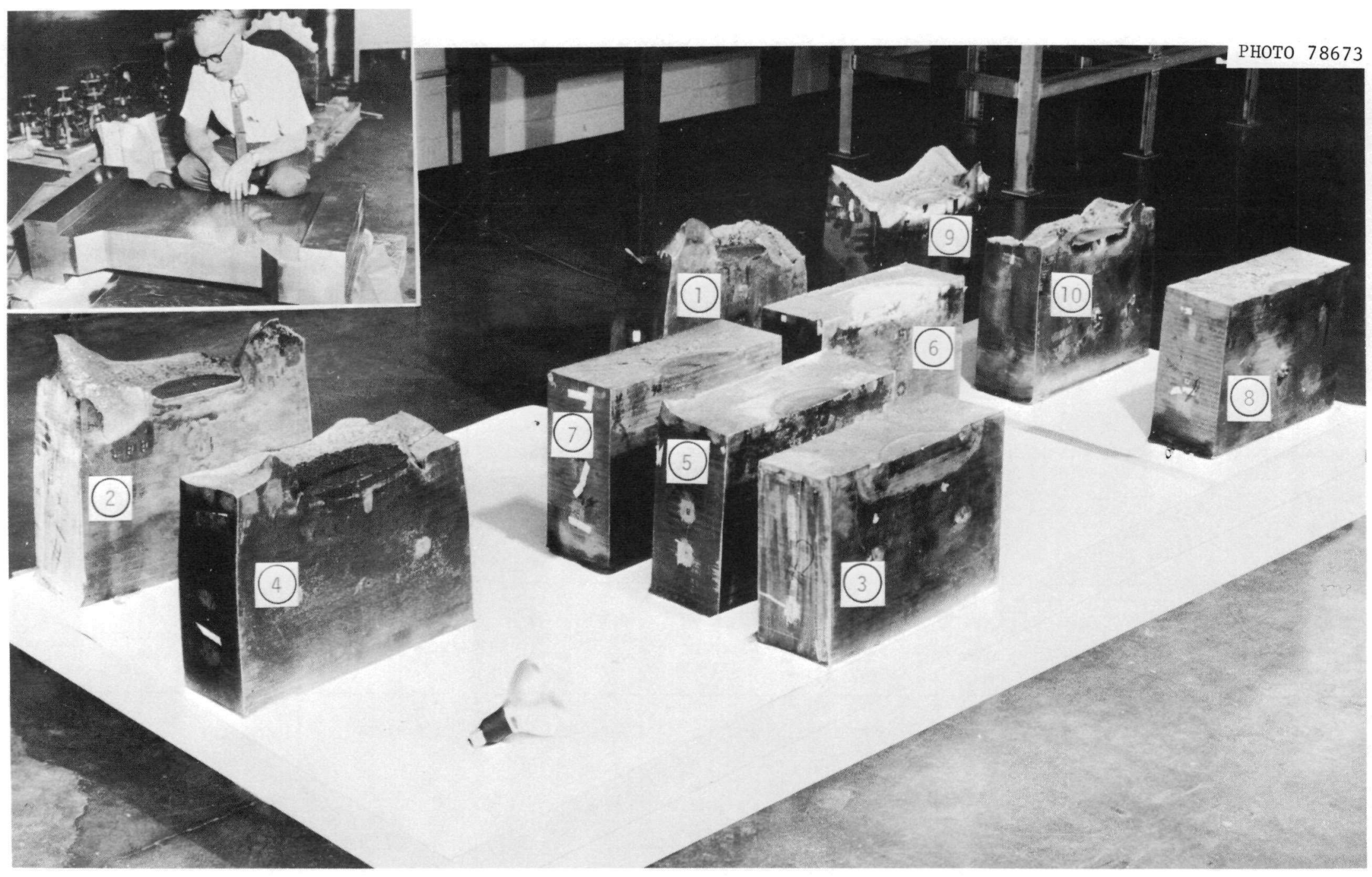

Fig. 5.4. Fracture Surfaces of Ten Flawed 6-in.-Thick Tensile Specimens. (See Table 5.1 for test parameters and results.) 
5. T. R. Mager, Fracture Toughness Properties of Heavy Section A 533, Grade B, Class 1 Steel Plate and Submerged Arc Weldment (to be published in Nuclear Engineering and Design).

6. T. R. Mager, Fatigue Crack Growth Characteristics of Nuclear Pressure Vessel Grade Materials, paper presented at the Fifth Annual Information Meeting of the Heavy Section Steel Technology Program, Oak Ridge National Laboratory, March 25-26, 1971.

\subsection{DESIGN CRITERIA FOR PIPING, PUMPS, AND VALVES \\ (AEC Activity 04608003 1)}

\section{B. L. Greenstreet S. E. Moore}

Basic structural information and design data are being developed for assuring the continued adequate and safe design of piping systems for nuclear service. The ORNL work is primarily concerned with piping components and is part of a larger AEC-industry cooperative program for developing piping, pump, and valve design criteria. Through this program factors urgently needed for use in both industry and AEC-RDT codes and standards are being developed that delineate design practices commensurate with meeting reliability and safety requirements of modern nuclear power plants.

Primary tasks to be carried out under the ORNL piping program are accurate, thorough experimental and analytical stress analyses of pipe fittings. At present, the experimental work is confined to tees, branch connections, and elbows, while analytical studies are planned for all standard pipe fittings. From the analyses and companion studies, data correlations and evaluations will be made; design charts, graphs, and tables will be prepared; and code rules will be drafted for use by the various code bodies. Data will be presented in terms of stress indices and flexibility factors for direct use. Overall interpretive reports will also be written on work sponsored under this program and that done by others.

In support of the ORNL management responsibility for the AEC-funded portion of the joint AEC-industry cooperative program, ORNL has been charged with keeping the AEC and industry fully informed through the Pressure Vessel Research Committee (PVRC) of the Welding Research Council. 
Periodically subcomittees of the PVRC and working task groups of the subcommittees meet to discuss the various research tasks.

During this reporting period a meeting of the PVRC Subcommittee to Develop Stress Indices for Piping, Pumps, and Valves was held in Oak Ridge on April 29; and a meeting of Task Group No. 1 of the Subcommittee was held on April 27. The Third Annual Information Meeting on Studies in Applied Solid Mechanics was also held in Oak Ridge on April 26-28, at which time 15 prepared discussions were presented concerning various research tasks under the ORNL piping program.

\section{Survey Reports}

There is nothing to report this period.

\section{Structural Analyses of Tees}

The structural analysis of ASA B16.9 tees is one of the more complex portions of the program, since essentially no information previously existed that could be used to develop stress indices for combined loadings. Studies for B16.9 tees, under the ORNL program, include experimental stress analysis and low-cycle fatigue tests of 15 tees that represent the "standard product" of three different manufacturers, thermal stress tests, photoelastic model studies, and the development of finite-element computer analyses. ' Portions of the work are being done at Oak Ridge National Laboratory and under subcontract at the University of California, Southwest Research Institute, Combustion Engineering, Inc., and Westinghouse Research Laboratories.

Studies are also being conducted at Oak Ridge and at Auburn University on thin-shell idealized tees and branch connections. Progress on the tee studies during this reporting period is briefly described below.

\section{Elastic Response Tests of ASA B16.9 Tees}

The four 24-in. ASA B16.9 tees identified below are being experimentally stress analyzed and fatigue tested at Combustion Engineering, Inc., in Chattanooga, Tennessee: 


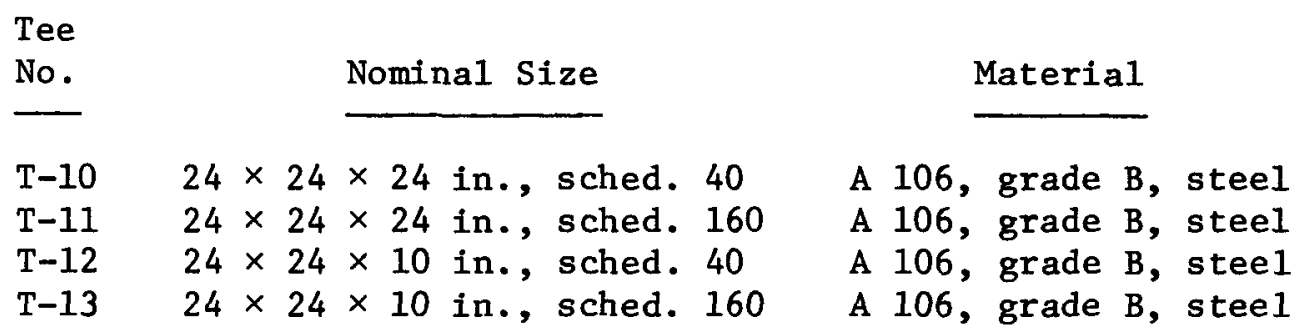

Currently $\mathrm{T}-11$ is being tested for elastic response for the same loading conditions as those used on $\mathrm{T}-10$; that is, internal pressure, and inplane, out-of-plane, and torsional bending moments on the branch and run pipe extensions, as well as transverse and direct thrust loadings on the branch and run pipes. At the end of April, tests for seven of these loadings had been completed.

Elastic response tests have also been conducted at Southwest Research Institute for the five 12-in. ASA B16.9 tees listed below:

Tee

No. Nominal Size Material

T-4 $12 \times 12 \times 12$ in., sched. $80 \quad$ A 106, grade B, steel

T-6 $12 \times 12 \times 12$ in., sched. 80 A 106, grade B, steel

T-7 $12 \times 12 \times 12$ in., sched. 160 Type 304L stainless steel

T-8 $12 \times 12 \times 6$ in., sched. 40 Type 304L stainless steel

T-15 $12 \times 12 \times 6$ in., sched. 40 Type 304L stainless steel

All data from the CE and SWRI tests have been examined at ORNL and, with the exception of two loading cases for $\mathrm{T}-6$, which are being rerun, the results indicate that the tests were quite satisfactory and accurate. Maximum normalized stress intensities calculated from the three-gage strain rosette readings for internal pressure and individual moment loadings applied to the branch and run pipe extensions are listed in Table 5.2. These numbers may be used directly to establish stress indices for individual loadings. However, it must be recognized that since the maximum stress intensities occur at different positions for the individual loadings, certain combined loading conditions will lead to larger stress, intensities at other positions on the body of the tee. This fact leads to complications in developing stress indices for code use which, by design, must be conservative for any arbitrary combination of loadings. Work along these lines is currently in progress. 
Table 5.2. Maximum Stress Intensities for B16.9 Tees

\begin{tabular}{|c|c|c|c|c|c|c|c|}
\hline \multirow{3}{*}{ Tee } & \multirow{3}{*}{$\begin{array}{l}\text { Normalized } \\
\text { Internal } \\
\text { Pressure }\end{array}$} & \multicolumn{6}{|c|}{ Normalized Stress Intensities ${ }^{a}$} \\
\hline & & \multicolumn{3}{|c|}{ Branch Moment Loadings } & \multicolumn{3}{|c|}{ Run Moment Loadings } \\
\hline & & In-Plane & Out-of-P1ane & Torsional & In-Plane & Out-of-Plane & Torsional \\
\hline $\begin{array}{l}\mathrm{T}-4 \\
\mathrm{~T}-6 b \\
\mathrm{~T}-7 \\
\mathrm{~T}-8 \\
\mathrm{~T}-10 \\
\mathrm{~T}-15\end{array}$ & $\begin{array}{l}4.40 \\
3.202 \\
6.058 \\
2.636 \\
2.871 \\
3.590\end{array}$ & $\begin{array}{l}2.250 \\
2.268 \\
1.729 \\
1.206 \\
3.796 \\
1.610\end{array}$ & $\begin{array}{l}3.011 \\
2.862 \\
2.002 \\
2.241 \\
3.661 \\
2.307\end{array}$ & $\begin{array}{l}2.739 \\
2.656 \\
2.189 \\
1.165 \\
3.599 \\
1.110\end{array}$ & $\begin{array}{l}2.013 \\
2.250 \\
1.425 \\
2.006 \\
3.102 \\
1.893\end{array}$ & $\begin{array}{l}1.231 \\
1.216 \\
1.450 \\
1.369 \\
1.604 \\
1.367\end{array}$ & $\begin{array}{l}2.322 \\
2.243 \\
1.737 \\
1.824 \\
3.573 \\
1.979\end{array}$ \\
\hline
\end{tabular}

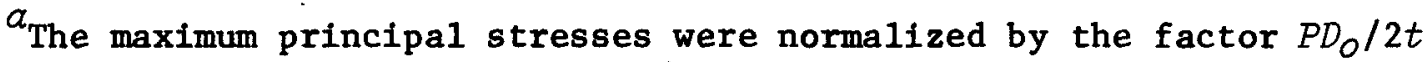

for internal pressure loading, and $M / Z$ for moment loading, where $Z=$

section modulus, $D_{0}=$ nominal outside diameter, and $t=$ nominal wall thick-

ness of stralght pipe with correspondong size and schedule numbers.

$b_{\text {Data }}$ for T-6 are preliminary. 


\section{Finite-Element Stress Analysis of B16.9 Tees}

Concurrently with the experimental studies of tees discussed above, a finite-element computer code for the elastic stress analysis of ASA B16.9 tees under arbitrary loadings is being developed at the University of California under the direction of Professors Clough and Powell. The computer program is expected to require only a small amount of data preparation and to produce stress output in an easily interpreted form. The detailed stress analysis of three of the 12-in. tees (T-6, T-7, and T-8) tested at Southwest Research Institute and comparison with experimental results are included in the scope of work as part of the proof of the analysis.

Results of finite element calculations and strain-gage and photoelastic experiments were compared previous $1 y^{2}$ for $T-8$ with an out-ofplane bending moment applied to the branch. Two additional loading cases for T-8 (internal pressure and in-plane bending moment on the branch) were calculated with the modified eight-node ZIB8R5 finite-element idealization and two different mesh layouts. One of the mesh arrangements was manually constructed from detailed measurements of the physical dimensions of the tee, and the other was generated automatically by the computer from a mathematically defined geometrical form. Both sets of results agree remarkably well with the experimental results obtained at SwRI, as shown in Figs. 5.5 and 5.6 .

Further work has also been done to improve the accuracy and efficiency of the basic finite-element idealizations. Several test problems were solved by using other modifications to the basic eight-node element. On the basis of these studies, an element with nine additional degrees of freedom, ZIB8R9, rather than five appears to give even better results over a wide range of diameter-to-thickness ratios. The results of these studies are described in a paper to be presented in Berlin, West Germany, this fa11. 3 


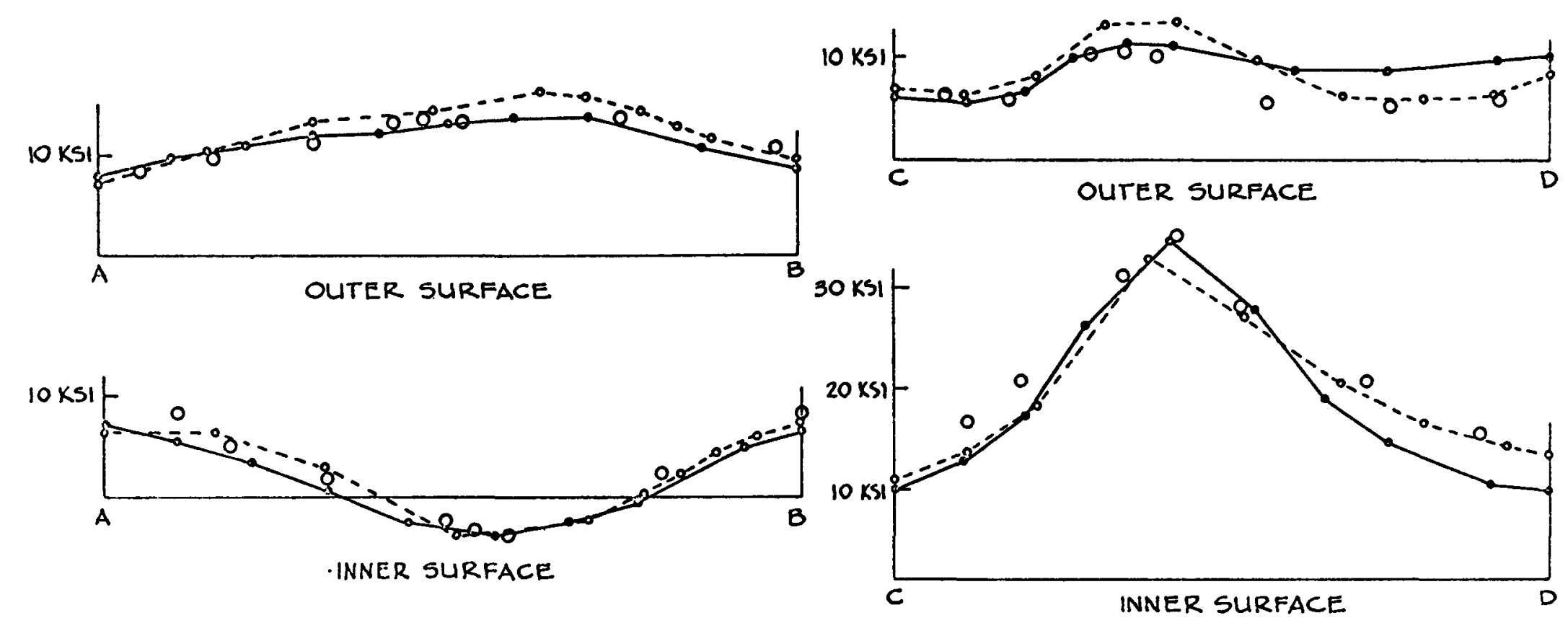

a) MAXIMUMM STRESSES ALONG LINE A-B

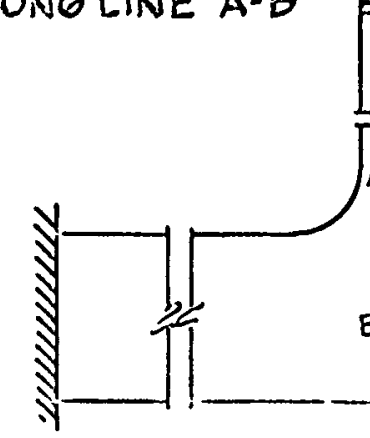

Fig. 5.5. Typical Results $12 \times 12 \times 6-1$. Sched. -40 Tee with InternalPressure Loading. (SwRI drawing)
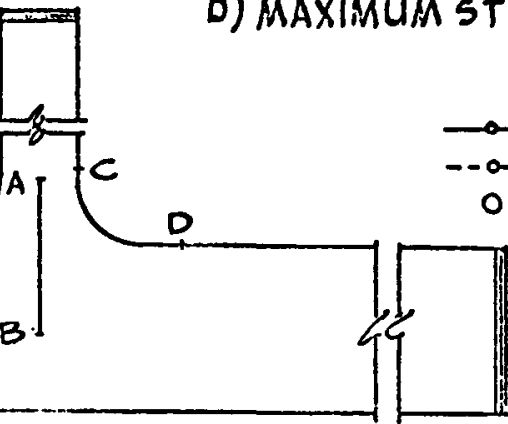

b) MAXIMUM STRESSES ALONG LINE C-D

- COMPUTED:MANUAL MESH

- O--COMPUTED:AUTOMATIC MESH

- EXPERIMENT 


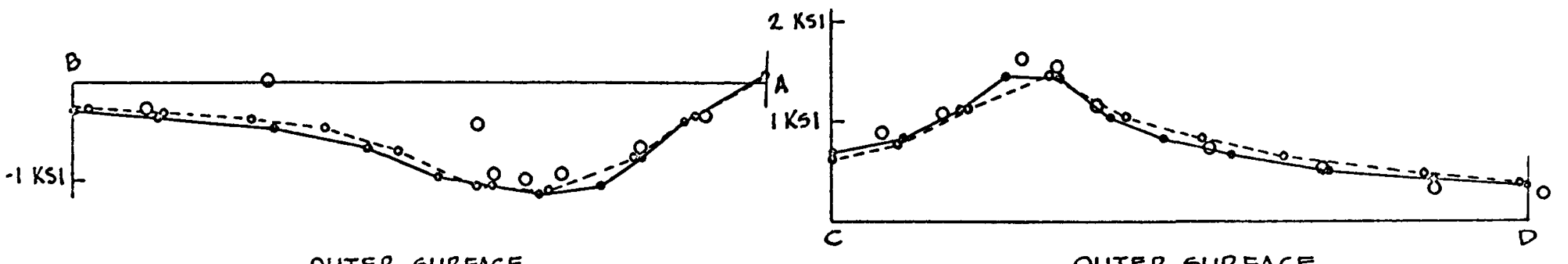

OUTER SURFACE

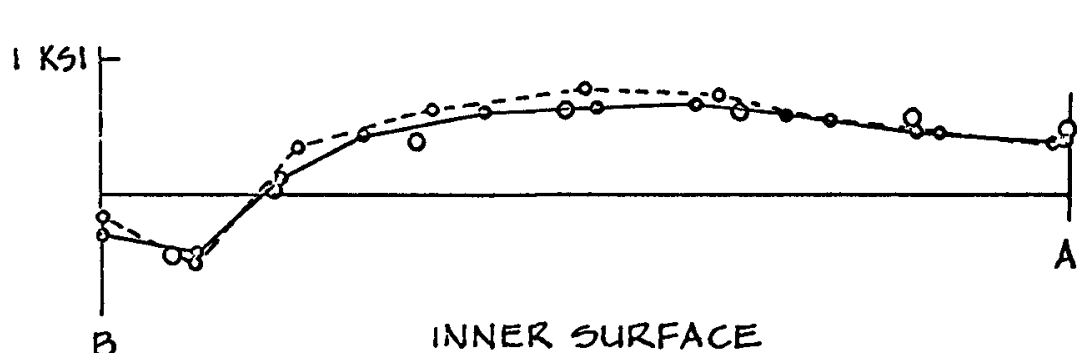

a) MAXIMUMM STRESSESALONG LINE B-A

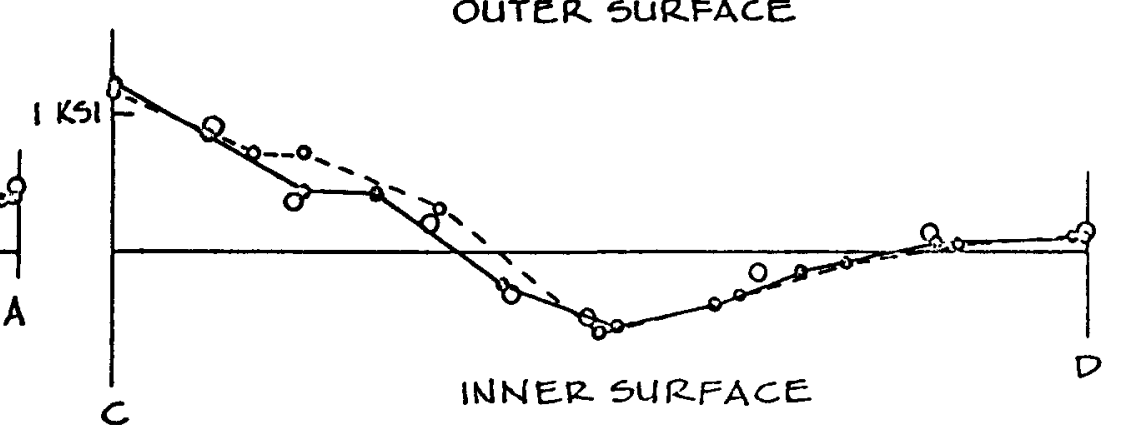

b) MAXIMUM STRESSES ALONG LINE $C-D$

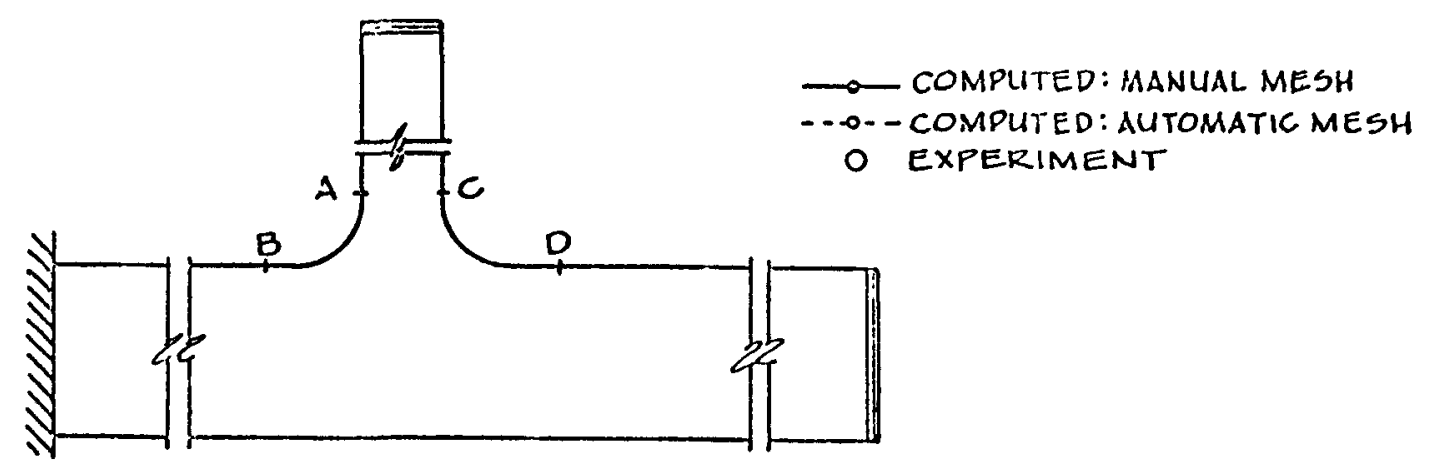

Fig. 5.6. Typical Results $12 \times 12 \times 6-1$. Sched. -40 Tee with In-Plane Moment Loading. (SwRI drawing) 
III. Thin-Walled Tees and Small Branch Connections

The series of four idealized thin-walled tees (cylinder-to-cylinder models) listed in Table 5.3 are being experimentally and analytically stress analyzed at Oak Ridge in cooperation with other ORNL programs as a means of obtaining high-quality data for use in developing better theoretical solutions. Each model in the series is well within the range of "thin-she11" theory, as indicated by the $D_{0} / T$ ratio, with the exception of the nozzle in model 3 , which has a $d_{0} / t$ ratio of 7.7 . There are no transition regions, reinforcements, or fillets at the functions; and the models are as geometrically perfect as can be obtained. All four models were fabricated and accepted from the vendor; and tests were completed on two of the models, 1 and 3 .

During this reporting period, strain-gage installation was completed for model 4, and currently the lead wires from the gages to the dataacquisition system are being connected. The model has 162 three-gage strain rosettes, each with active gage lengths of $0.030 \mathrm{in}$. The arrangement of the gages is identical with that for model 3, which has gages on

Table 5.3. Thin-She11 Cylinder-to-Cylinder Tee Models

\begin{tabular}{|c|c|c|c|c|c|c|c|c|}
\hline \multirow{2}{*}{$\begin{array}{c}\text { Model } \\
\text { No. }\end{array}$} & \multicolumn{4}{|c|}{ Major Dimensions $^{\alpha}$ (in.) } & \multicolumn{4}{|c|}{ Dimensionless Parameters } \\
\hline & $D_{0}$ & $d_{0}$ & $T$ & $t$ & $d_{0} / D_{0}$ & $D_{0} / T$ & $d_{0} / t$ & $s / S^{b}$ \\
\hline $\begin{array}{l}1 \\
2 \\
3 \\
4^{c}\end{array}$ & $\begin{array}{l}10.0 \\
10.0 \\
10.0 \\
10.0\end{array}$ & $\begin{array}{c}5.0 \\
10.0 \\
1.29 \\
1.29\end{array}$ & $\begin{array}{l}0.1 \\
0.1 \\
0.2 \\
0.2\end{array}$ & $\begin{array}{l}0.05 \\
0.1 \\
0.168 \\
0.064\end{array}$ & $\begin{array}{l}0.5 \\
1.0 \\
0.129 \\
0.129\end{array}$ & $\begin{array}{r}100 \\
100 \\
50 \\
50\end{array}$ & $\begin{array}{r}100.0 \\
100.0 \\
7.7 \\
20.2\end{array}$ & $\begin{array}{l}1.00 \\
1.00 \\
0.154 \\
0.40\end{array}$ \\
\hline $\begin{array}{r} \\
\text { the or } \\
\text { thickr } \\
\text { nozzle } \\
b \\
\text { the no } \\
\text { nal pl }\end{array}$ & $\begin{array}{l}\text { is th } \\
\text { ide d: } \\
\text { s of } \\
\text { e dim } \\
\text { le to } \\
\text { sure }\end{array}$ & $\begin{array}{l}\text { utsid } \\
\text { ter o } \\
\text { cylin } \\
\text { onles: } \\
\text { memb } \\
\text { ing; }\end{array}$ & $\begin{array}{l}\text { iamet } \\
\text { he no } \\
\text { cal s } \\
\text { arame } \\
\text { e str } \\
\text { terms }\end{array}$ & $\begin{array}{l}\text { of the } \\
\text { le (the } \\
11 \text {; anc } \\
\text { r s/S } \\
\text { s in th } \\
\text { f othes }\end{array}$ & $\begin{array}{l}\text { arger } \\
\text { maller } \\
\text { is th } \\
\text { the r } \\
\text { cyling } \\
\text { aramet }\end{array}$ & $\begin{array}{l}\text { ndric } \\
\text { inder } \\
11 \text { th } \\
\text { of me } \\
1 \text { she } \\
s / S\end{array}$ & $\begin{array}{l}\text { shell; } \\
T \text { is } \\
\text { kness } \\
\text { rane st } \\
\text { due to } \\
d / D \times T\end{array}$ & $\begin{array}{l}\text { is } \\
\text { wall } \\
\text { the } \\
\text { ss in } \\
\text { nter- } \\
\text {. }\end{array}$ \\
\hline
\end{tabular}


the inner and outer surfaces on lines at $0,90,180,270$, and $315^{\circ}$ from the longitudinal axis of the model.

IV. Elbows, Curved Pipe, and Miter Bends

Limit-load tests on a series of 6-in. standard elbows were reported previously to show marked differences in the behavior of elbows made from stainless steel and carbon steel when all other variables in the tests were the same. ${ }^{4}$ In order to confirm this finding, a second 6-in. stainless steel elbow was tested. The specimen was prepared and tested in the same manner as the first, with an in-plane bending moment applied to the pipe extension and loaded until the load-deflection curves indicated predominantly plastic behavior. The second model was more extensively instrumented than the first, with brittle lacquer, ten three-gage strain rosettes, and additional dial gages in order to insure that the results were not caused by some unknown factor in the test setup. Both tests gave essentially the same results; that is, the limit load for the stainless steel elbow was about one-half that for the carbon steel elbow. It is concluded therefore that the type of material is an important variable in governing plastic collapse of structures and should be considered in design rules for codes and standards.

\section{Structura1 Analysis of Other Piping Components}

The development of secondary stress indices for integral structural attachments on straight pipe was completed and a report was drafted. ${ }^{5}$ These stress indices, along with an appropriate simple equation, allow the designer to calculate maximum stress intensities existing in the pipe as a result of thrust or moment loadings transmitted through a lug support. The stress indices were developed by using the theoretical works of Bjilaard, the summary and modification of his work by Wichman, Hopper, and Mershon, and the philosophy of the nuclear piping code USAS B31.7-1969. The code philosophy is that a conservative estimate of the maximum stress intensity in a piping component loaded with a combination of applied loadings may be obtained by direct addition of the maximum stress intensities 
caused by each load applied separately. Thus in the present formulation the maximum stress intensity in the pipe as a result of thrust and moment loadings on the integral attachment can be obtained from the formula

$$
S=\frac{1}{Z}\left(M_{R}+C_{L} M_{L}+C_{C} M_{C}\right)+C_{T} \frac{T}{A}
$$

where

$$
\begin{aligned}
S= & \text { stress intensity, } \\
Z= & \text { section modulus of the pipe, } \\
A= & \text { cross-sectional area of the pipe, } \\
M_{R}= & \text { static moment in the pipe run, } \\
M_{L}, M_{C}, T= & \text { longitudinal moment, circumferential moment, and thrust } \\
& \text { loading on the attachment, respectively, } \\
C_{L}, C_{C}, C_{T}= & \text { stress indices for the respective loadings. }
\end{aligned}
$$

Numerical values for the stress indices $C_{L}, C_{C}$ and $C_{T}$ were calculated and tabulated over a suitable range of parameters for nuclear piping systems, and the results were used to develop a simple and conservative equation for computational purposes. The report will be published in the near future.

\section{References}

1. W. L. Greenstreet, S. E. Moore, and R. C. Gwaltney, Progress Report on Studies in Applied Solid Mechanics, USAEC Report ORNL-4576, Oak Ridge National Laboratory, August 1970.

2. B. L. Greenstreet and S. E. Moore, Design Criteria for Piping, Pumps, and Valves, pp. 63-73, ORNL Nuclear Safety Research and Development Program Bimonthly Report for January-February 1971, USAEC Report ORNL-TM-3342, Oak Ridge Nationa1 Laboratory, May 1971.

3. R. W. Clough, G. H. Powe11, and A. N. Gantayat, Stress Analysis of B16.9 Tees by the Finite Element Method, paper to be presented at the First International Conference on Structural Mechanics in Reactor Technology, Berlin, Germany, September 20-24, 1971.

4. B. L. Greenstreet and S. E. Moore, Design Criteria for Piping, Pumps, and Valves, pp. 80-86, ORNL Nuclear Safety Research and Development Program Bimonthly Report for November-December 1970, USAEC Report ORNL-TM-3263, Oak Ridge National Laboratory, March 1971. 
5. W. G. Dodge, Secondary Stress Indices for Integral Structural Attachments to Straight Pipe (to be published).

\subsection{EXPERIMENTAL AND ANALYTICAL INVESTIGATIONS OF NOZZLES}

(AEC Activity $0406 \quad 7001$ 1)
B. L. Greenstreet
J. P. Callahan

The junctures of connecting nozzles with a pressure vessel are highly stressed regions when either the vessel is subjected to internal pressure or the nozzles are subjected to moment or thrust loadings. Consequently, in the design of a nuclear reactor pressure vesse1, the designer must accurately predict the magnitudes and locations of maximum stresses at these regions. The nozzles program is designed for developing analytical procedures capable of identifying the maximum stresses and providing adequate experimental verification of the procedures. Included in the program are studies of single nozzles radially and nonradially attached to spherical shells, perforated flat plates and spherical shells, clusters of nozzles attached to flat plates and spherical shells, and nozzles attached to cylindrical shells. Additional factors to be investigated include the effect of superposition of various loadings on the nozzle, mutual interactions between adjacent openings and nozzles, and possible design limitations for nonradial or hillside nozzles. Close cooperation is maintained with subcommittees of the Pressure Vessel Research Committee (PVRC) of the Welding Research Council. The results from the research efforts are prepared in the form of computer programs, design charts, and tables for use in establishing design rules for both industrial and AEC-RDT codes and standards. The use of this information will provide means for assuring that reliability and safety requirements of the standards are met.

\section{Project Management}

As a member of the Pressure Vessel Research Committee, ORNL has been assigned the task of coordination, review, and evaluation of the research 
programs for the PVRC Subcommittee on Reinforced Openings and External Loadings. Included in this management function are: (1) direction of AEC-sponsored work, including both the work at ORNL and the work under subcontract, (2) generation of parameter studies in support of code-oriented evaluation and correlation work being performed under subcontract at Battelle Memorial Institute, (3) reporting and making recommendations to the subcomittee on non-AEC-sponsored projects, and (4) soliciting comments and recommendations from the PVRC Subcommittee concerning AECsponsored work.

A meeting of the PVRC Subcommittee on Reinforced Openings and External Loadings was held in Oak Ridge in conjunction with the annual ORNL information meeting on Studies in Applied Solid Mechanics held on Apri1 26-28, 1971. The current status of the various projects was discussed at these meetings. An oral progress report will also be made at a meeting of the PVRC Design Division in New York on May 25, 1971.

\section{Single Nozzles in Spherical She1ls}

Work is continuing at the University of Tennessee on two hemispherical models with single radial and nonradial nozzles.

The last of the planned series of radial nozzles, model 807-003, which has an outside diameter of 7.002 in., is being instrumented with straingage rosettes. A $221 / 2^{\circ}$ nonradial nozzle, model 802-222, which has an outside diameter of $2.625 \mathrm{in}$, is currently being tested under axial thrust loading.

\section{Single Radial Nozzles in Cylindrical Shells}

A report describing photoelastic investigations conducted at Westinghouse Research Laboratories for stresses at two closely spaced reinforced nozzles was published. ${ }^{1}$ Two cylindrical vessel models were tested under internal pressure loading. Vessel 1 (Westinghouse photoelastic model 3), shown in Fig. 5.7, is a relatively thick-walled vessel with an inside diameter-to-thickness ratio $\left(D_{i} / T\right)$ of 12.25 ; vessel 2 (Westinghouse photoelastic model 4), shown in Fig. 5.8, is a relatively thin-walled vessel 


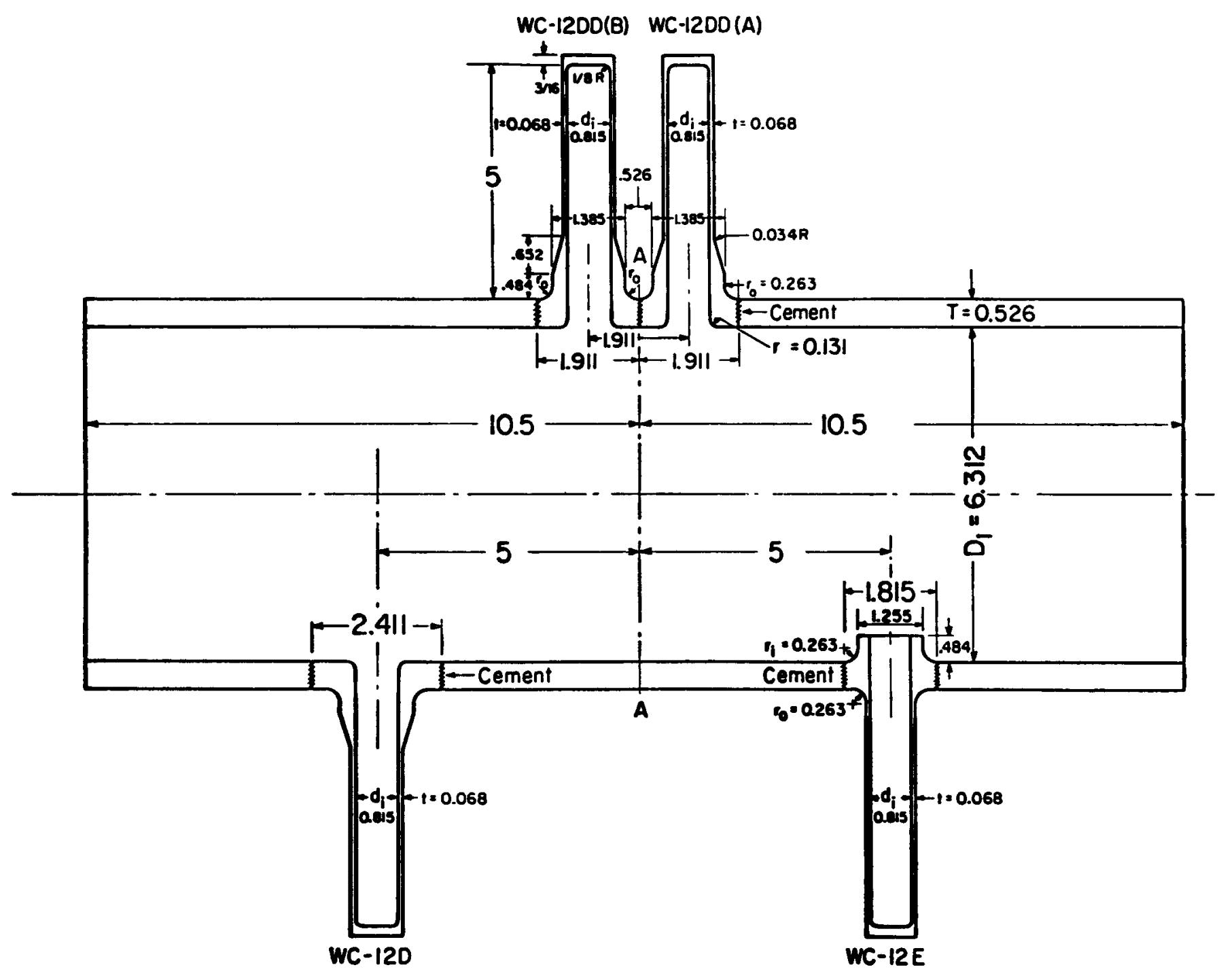

Fig. 5.7. Shape and Nominal Dimensions of Cylindrical Vesse1 1 Containing Two Closely Spaced Openings WC-12DD (A) and (B), Single Opening WC-12D, and Inward Protruding Nozzle WC-12E. (Westinghouse Electric Corporation drawing) 


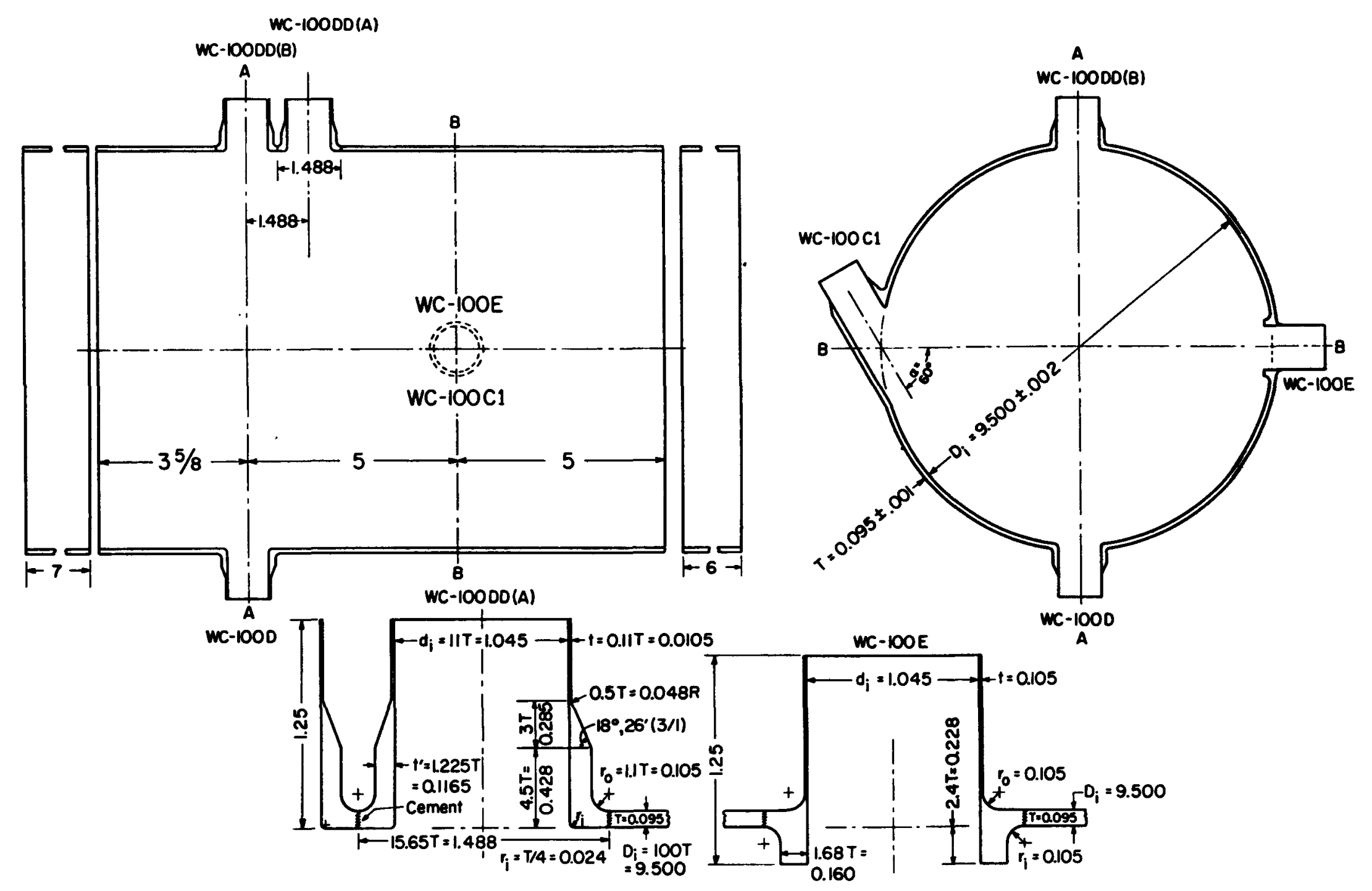

Fig. 5.8. Shape and Nominal Dimensions of Cylindrical Vessel 2 Containing Two Closely Spaced Reinforced Openings WC-100 DD (A) and (B), Single Opening WC$100 \mathrm{D}$, Inward Protruding Nozzle WC-100 E, and the $60^{\circ}$ Hillside Nozzle WC-100 C1. (Hestinghouse Electric Corporation drawing) 
with a $D_{i} / T$ ratio of 101.7 . Also shown in the figures are the two closely spaced reinforced nozzles, WC-12DD and WC-100DD, respectively, as well as companion single nozzles of the same shape and size designated as WC-12D and WC-100D. Each model also contains an inwardly protruding nozzle designated in the figures as WC-12E and WC-100E. In addition, a $60^{\circ}$ hillside reinforced nozzle, WC-100C1, was attached to model 4. All components were machined from solid castings of anhydride-cured epoxy resin. The nozzles were machined separately and cemented into holes bored in the vessels.

The principal stresses for each nozzle were determined by the photoelastic method of freezing and slicing. ${ }^{2}$ The stresses normal to the plane $\left(\sigma_{n}\right)$ and those in the plane of the longitudinal slices $\left(\sigma_{t}\right)$ were analyzed. A comparison of stress patterns for the longitudinal sections ( 0 and $180^{\circ}$ ) of single nozzle WC-12D with closely spaced nozzle WC-12DD(A) is shown in Fig. 5.9. The difference in stresses is greatest at point $J$ on the outer surface. The stress patterns for the transverse sections of the same two nozzles are shown in Fig. 5.10. Taking into consideration experimental error, the shapes of the stress distributions do not differ significantly. The stress patterns for the longitudinal slices of nozzles WC-100D and WC-100DD(A) are shown in Fig. 5.11 for $\sigma_{t}$ and Fig. 5.12 for $\sigma_{n}$. The difference in principal stress ratios between the two nozzles is greatest for $\sigma_{t} / S$ at points $J$ and $B$ in Fig. 5.11. The stress patterns for the transverse sections $\left(90\right.$ and $\left.180^{\circ}\right)$ of nozzles WC-100D and WC-100DD(A) are shown in Fig. 5.13. The stress was significantly higher on the outer surface of nozzle WC-10ODD at the junction of the nozzle and the vessel.

The maximum measured circumferential principal stresses $\sigma_{n}$ developed at the inner corners of the nozzles are listed in Table 5.4 for the 0 and $180^{\circ}$ sections. Also shown in the table are ratios of peak circumferential stresses for closely spaced nozzles to those for single nozzles. The four ratios in Table 5.4 are plotted in Fig. 5.14 and show excellent agreement with the results of Ling for closely spaced holes in an infinite plate subjected to biaxial stress. ${ }^{3}$ The stresses given in Table 5.4 were higher than those obtained for any of the single openings tested, with the exception of the inwardly protruding radial nozzle, WC-100E, which 
WC-12 DD and WC-12D: Longitudinal Section

Principal Stress Ratio $\sigma_{\mathrm{t}} / \mathrm{S}$ :

$0-0$ WC-12DD, $0^{\circ}$ Section

-0 WC-12DD, $180^{\circ}$ Section

Principal Stress Ratio $\sigma_{n} / S$ :

$\triangle-\triangle W C-120,0^{\circ} \& 180^{\circ}$ Sections

$\longrightarrow W C-12 D D, 0^{\circ}$ Section

$\longrightarrow$ WC- 1200 , $180^{\circ}$ Section

$\longrightarrow W C-120,0^{\circ} \& 180^{\circ}$ Sections

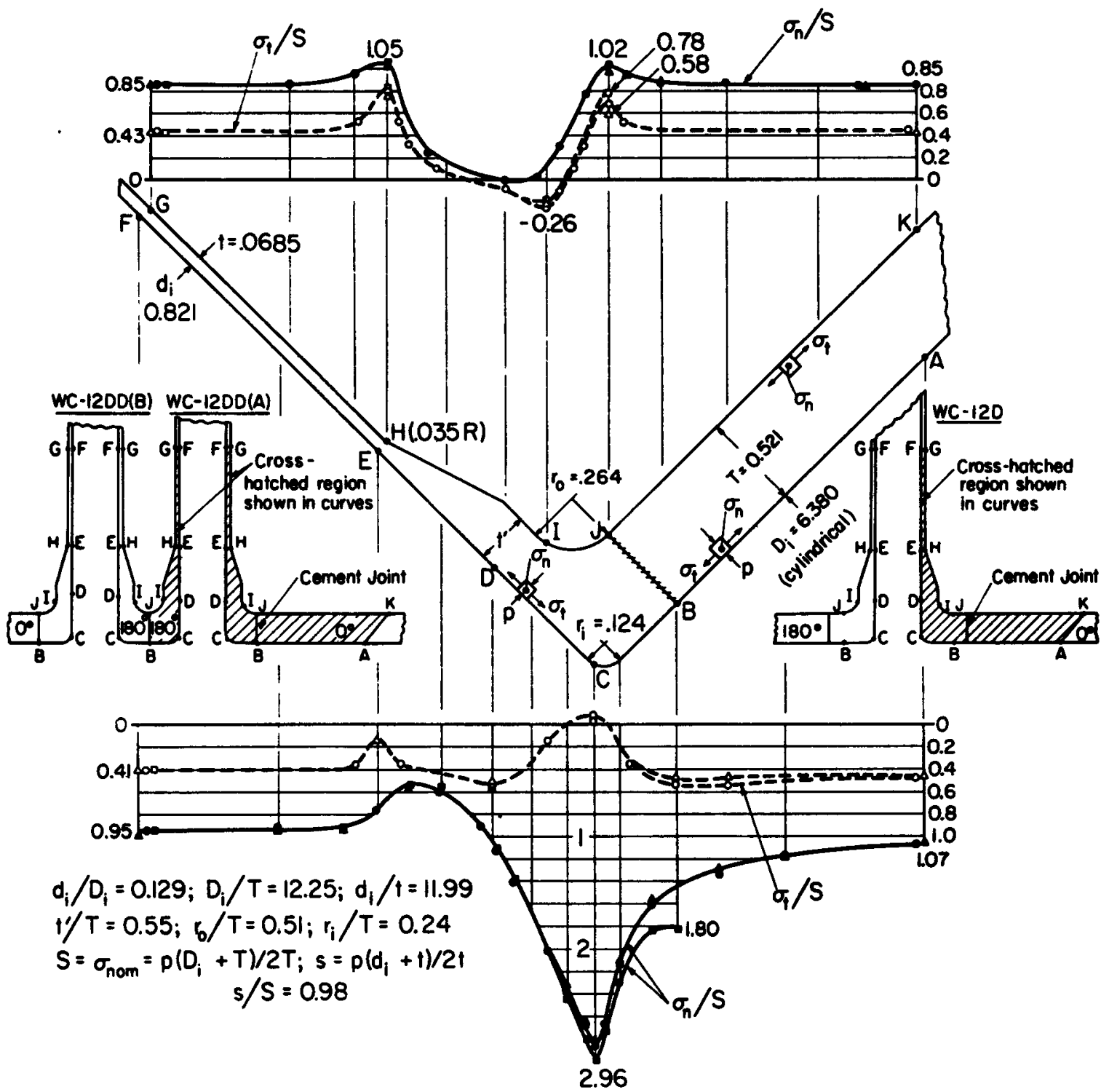

Fig. 5.9. Comparison of Principal Stress Ratios $\sigma_{t} / S$ and $\sigma_{n} / S$ on the Inner and Outer Surfaces of the Axial Section of Symmetry $\left(0^{\circ}\right.$ and $\left.180^{\circ}\right)$ for the Two Closely-Spaced Reinforced Nozzles WC-12DD (A) and (B) and the Identical Single Nozzle WC-12D in a Thick-Walled Cylindrical Vessel Subjected to Internal Pressure. (Westinghouse Electric Corporation drawing) 
WC-12DD and WC-12D: Transverse Sections

- - - - - P Principal stress rotio $\sigma_{\uparrow} / \mathrm{S}$

- $W C-1200,90^{\circ}$ and $270^{\circ}$ sections

$\longrightarrow$ Principal stress ratio $\sigma_{n} / S$

- $W C-1200,90^{\circ}$ and $270^{\circ}$ sections

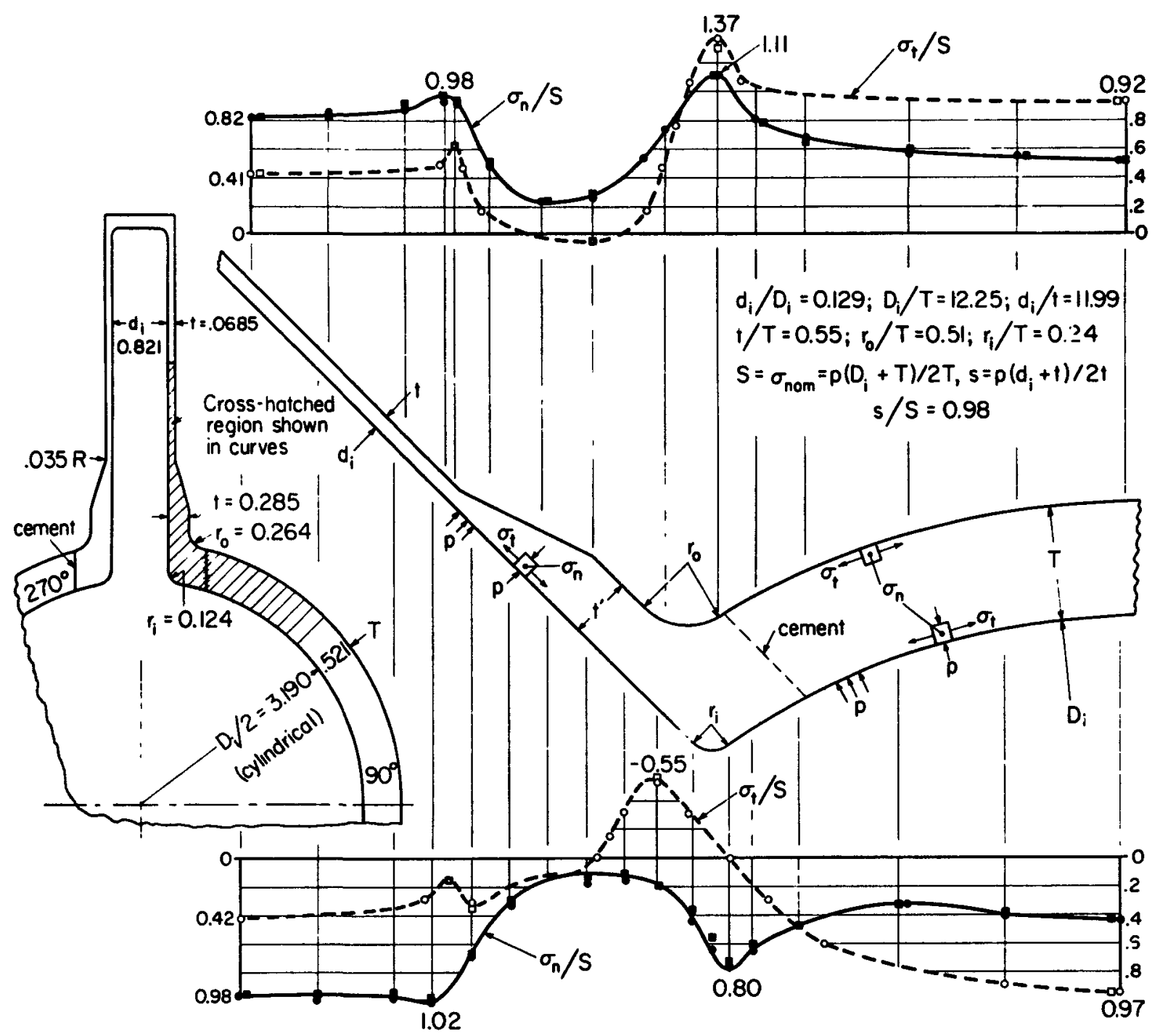

Fig. 5.10. Principal Stress Ratios $\sigma_{t} / S$ and $\sigma_{n} / S$ on Inner and Outer Surfaces of the Transverse Sections $\left(90^{\circ}\right.$ and $270^{\circ}$ ) for the Two Closely Spaced Reinforced Nozzles WC-12DD (A) and (B) and the Identical Single Nozzle WC-12D in a Thick-Walled Cylindrical Vessel Subjected to Internal Pressure. (Westinghouse Electric Corporation drawing) 
Dwg. 7238133

WC- 1000 and WC-100DD: Longitudinal $\left(0^{\circ}\right.$ and $\left.180^{\circ}\right)$ Sections

Principal Stress Ratio $0 / S$

$\Longrightarrow W C-100 D, 0^{\circ} \& 180^{\circ}$ Sections

$0-\longrightarrow W C-10000$ iA) \& (B). $0^{\circ}$ Sections

$\Delta \rightarrow$ WC- 10000 . $180^{\circ}$ Sections

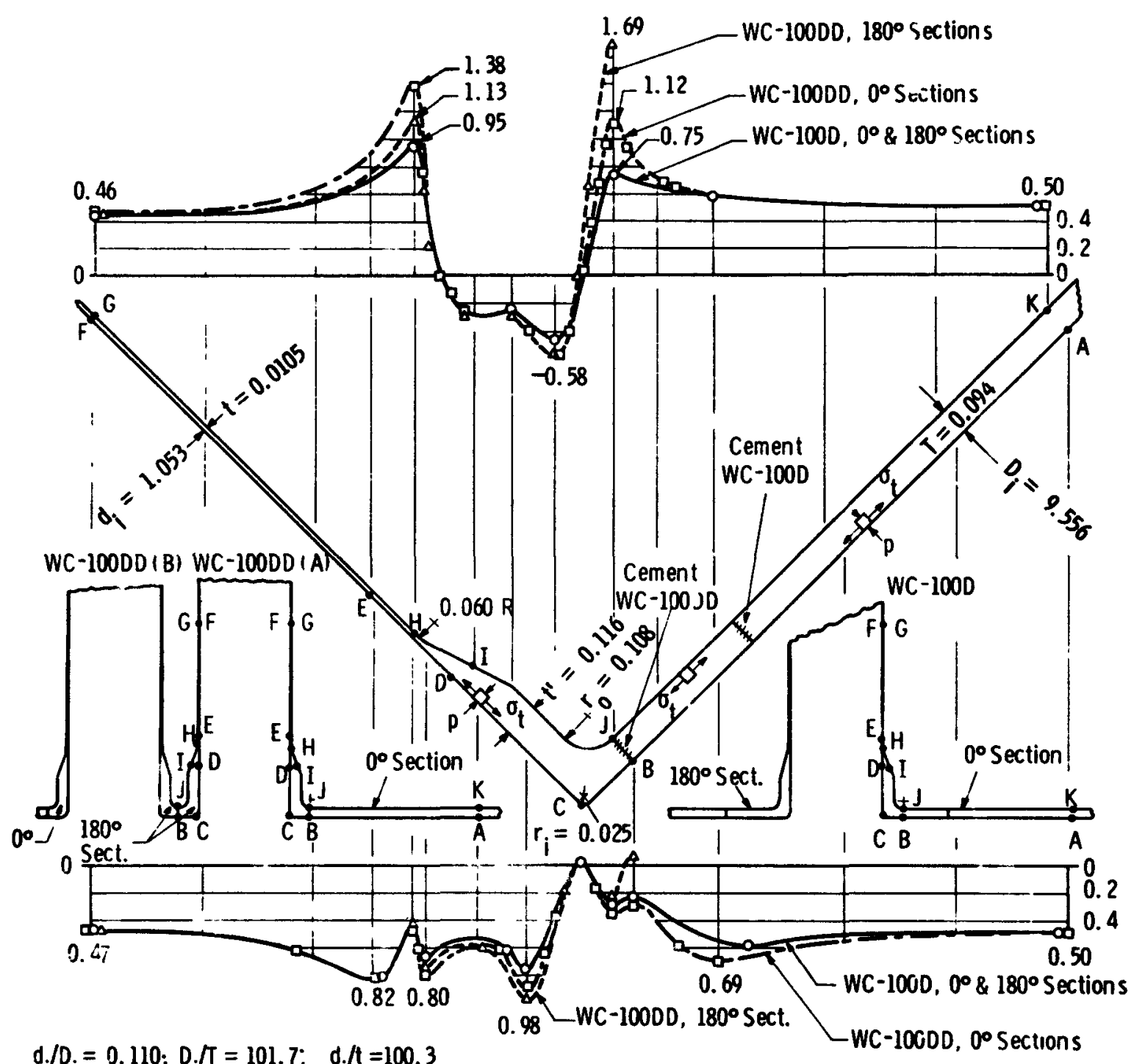

$d_{i} / D_{i}=0.110 ; D_{i} / T=101.7 ; \quad d_{i} / t=100.3$

$t^{\prime} / T=1.23 ; r_{0} / T=1.15 ; r_{i} / T=0.27 ; s / S=0.986$

$S=\sigma_{\text {nom }}=p\left(D_{i}+T\right) / 2 T ; s=p\left(d_{i}+t\right) / 2 t$

Fig. 5.11. Comparison of Principal Stress Ratio $\sigma_{t} / S$ on the Inner and Outer Surfaces of the Axial Section of Symmetry $\left(0^{\circ}\right.$ and $180^{\circ}$ Sections) for the Two Closely Spaced Reinforced Openings WC-100DD (A) and (B) and the Identical Single Opening WC-100D in a Thin-Walled Cylindrical Vessel Subjected to Internal Pressure. (Westinghouse Electric Corporation drawing) 
WC- 1000 and WC-100DD : Logitudinal $\left(0^{\circ}\right.$ and $\left.180^{\circ}\right)$ Sections

Dwg. 7238132

Principal Stress Ratio $\sigma_{n} / S$

$\Longrightarrow W C-1000,0^{\circ}$ and $180^{\circ}$ Sections

- $W C-100 D D(A)$ and $(B), \infty$ Sections

$\triangle W C-100 D D, 180^{\circ}$ Sections

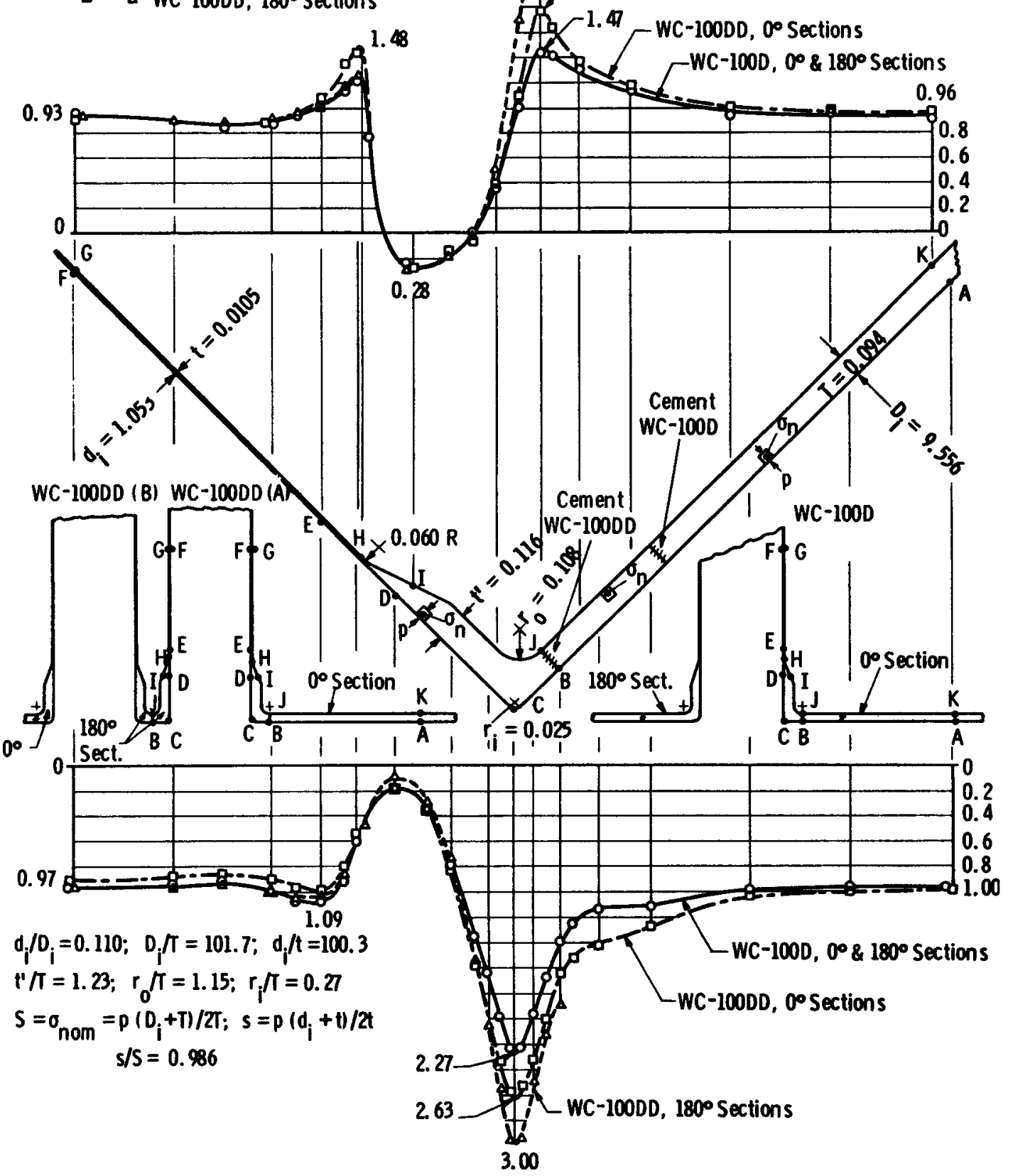

Fig. 5.12. Comparison of Principal Stress Ratio $\sigma_{n} / S$ on the Inner and Outer Surfaces of the Axial Section of Symmetry ( $0^{\circ}$ and $180^{\circ}$ Sections) for the Two Closely Spaced Reinforced Openings WC-100DD (A) and (B) and the Identical Single Opening WC-100D in a Thin-Walled Cylindrical Vessel Subjected to Internal Pressure. (Westinghouse Electric Corporation drawing) 
Dwg. 7238134

WC- 1000 and WC-100DD (A) and (B) Transverse $\left(90^{\circ}\right.$ and $\left.270^{\circ}\right)$ Sections

o---O Principal Stress Ratio ot $/ \mathrm{S}, W C-1000,90^{\circ} \& 270^{\circ}$ Sections

D-- D Principal Stress Ratio cy'S, WC-100DD (A) \& (B), 900 \& $270^{\circ}$ Sections

$\longrightarrow$ Principal Stress Ratio on $/ S$, WC-1000, $90^{\circ} \& 270^{\circ}$ Sections

$\longrightarrow$ Principal Stress Ratio on $/ 5$, WC-100DD (A) \& (B), $90^{\circ} \& 270^{\circ}$ Sections

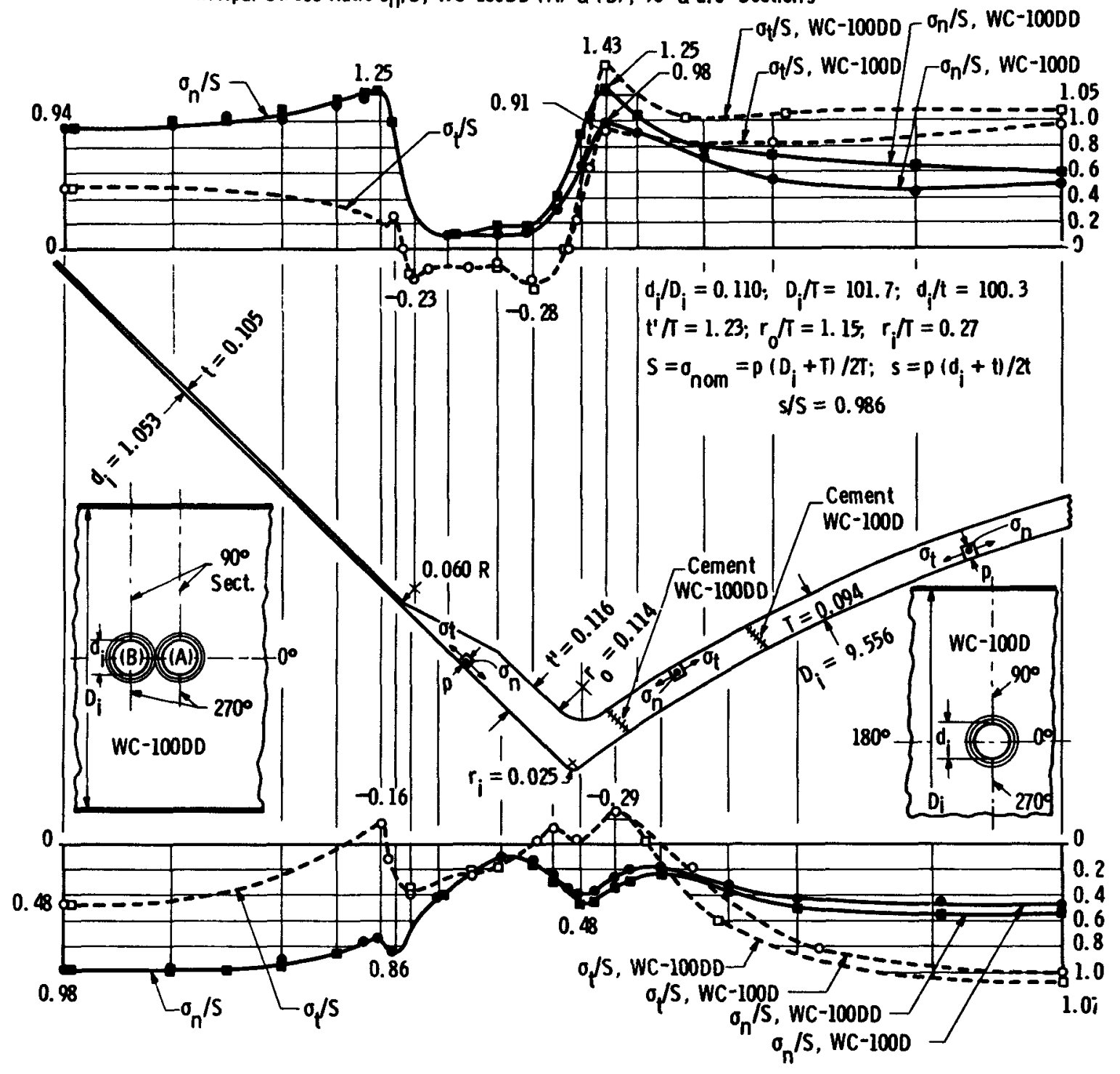

Fig. 5.13. Comparison of the Principal Stress Ratios $\sigma_{t} / S$ and $\sigma_{n} / S$ on the Inner and Outer Surfaces of the Transverse Sections $\left(90^{\circ}\right.$ and $\left.270^{\circ}\right)$ for the Two Closely Spaced Reinforced Openings WC-100DD (A) and (B) and the Identical Single Opening WC-100D in a Thin-Walled Cylindrical Vessel Subjected to Internal Pressure. (Westinghouse Electric Corporation drawing) 
Table 5.4. Ratio of Peak Circumferential Stresses Obtained for Closely Spaced Nozzles to Those of the Single Nozzle

\begin{tabular}{|c|c|c|c|c|c|c|}
\hline \multirow{2}{*}{ Model } & \multicolumn{2}{|c|}{ Maximum $\sigma_{n}$} & \multicolumn{2}{|c|}{$\begin{array}{l}\text { Ratio of }\left(\sigma_{n}\right)_{D D} \\
\text { to }\left(\sigma_{n}\right)_{D}\end{array}$} & \multicolumn{2}{|r|}{$L / d_{i}$} \\
\hline & $\begin{array}{c}0^{\circ} \\
\text { Section }\end{array}$ & $\begin{array}{l}180^{\circ} \\
\text { Section }\end{array}$ & $\begin{array}{c}0^{\circ} \\
\text { Section }\end{array}$ & $\begin{array}{l}180^{\circ} \\
\text { Section }\end{array}$ & (See & Fig. 5.14) \\
\hline WC-12D & 2.815 & $2.81 S$ & & & & $\infty$ \\
\hline WC-12DD & $2.87 S$ & $2.96 S$ & 1.02 & 1.05 & & 1.34 \\
\hline WC-100D & $2.27 S$ & $2.27 S$ & & & & $\infty$ \\
\hline WC-100DD & $2.63 S$ & $3.00 \mathrm{~S}$ & 1.16 & 1.32 & & 0.42 \\
\hline
\end{tabular}

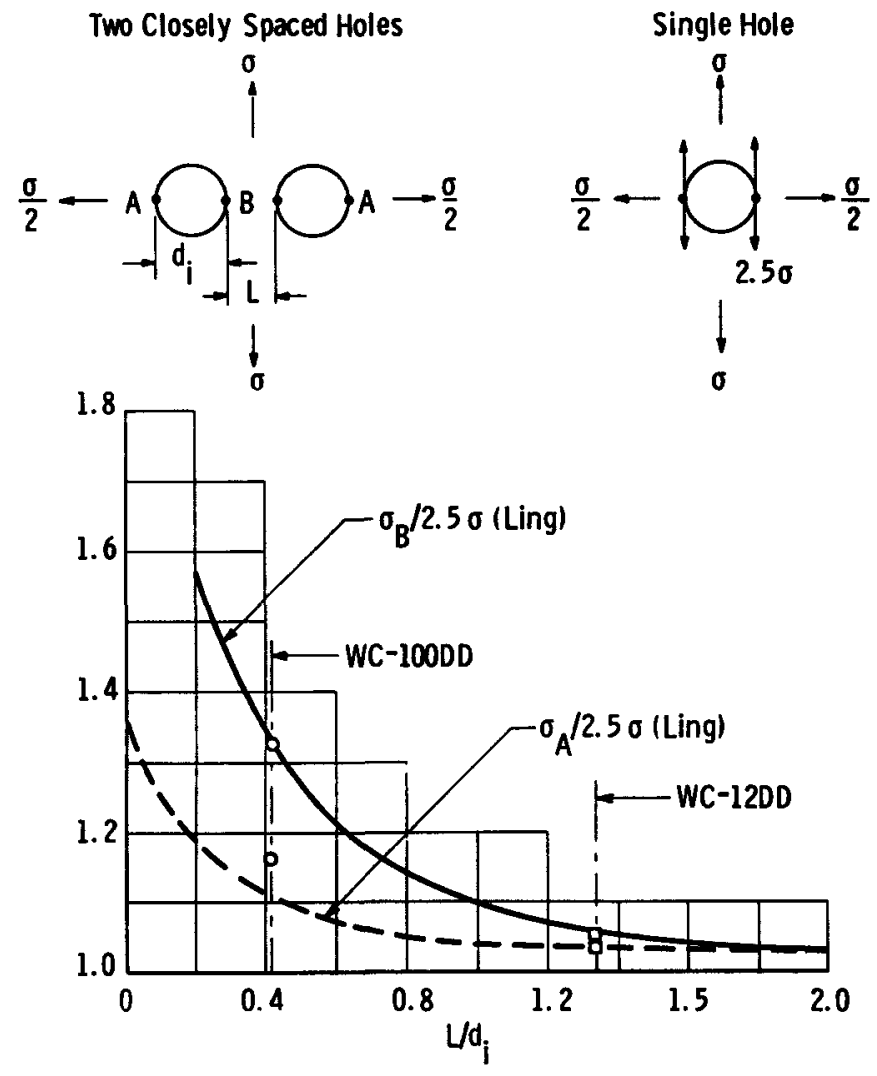

Fig. 5.14. Comparison of Stresses at Points A and B for Two Closely Spaced Reinforced Openings in a Pressurized Cylinder with the Stresses at Two Holes in an Infinite Plate. (Westinghouse Electric Corporation drawing) 
developed a peak stress of $\sigma_{n}=3.375$ at the outer fillet of the $0^{\circ}$ section.

\section{Clusters of Nozzles}

At Auburn University, instrumentation of the cluster of four radial nozzles attached to the steel hemispherical model 2 is under way. Threegage strain rosettes are now being attached and wired. The planned loading program for the flat-plate model with two attached nozzles was completed; however, several loadings are now being repeated to check the consistency of some data. The wiring of the strain gages attached to the three-nozzle flat-plate model was completed, and the model is ready for testing.

\section{Reinforcement Studies}

Parameter Study of Radial Nozzles Attached to Spherical Shells

The models thus far analyzed at ORNL in a study of triangular-pad reinforcement are listed in Table 5.5. The planned study of internal pressure loading was completed, and the results are now being interpreted. Additional Analyses of these models are planned for moment loadings and for a loading resulting from the introduction of a temperature difference between the nozzle and the spherical shell portion of the model. The results of these parameter studies are being used in code-rule development work at Battelle Memorial Institute.

\section{Finite-Element Analysis of Compact Reinforcement for}

\section{Radial Noz:? es}

six additional models were analyzed at ORNL by finite-element analyis to supply further data concerning the design of compact reinforcement for radial nozzles attached to spherical shells. In addition, model $\mathrm{S}-24 \mathrm{E}$ was analyzed for Poisson's ratios of 0.3 and 0.49 . The maximum $s$ resses and a description of the reinforcing for each model are given in Table 5.6.

The results of the analyses of model S-24E for Poisson's ratios of 0.3 and 0.49 are shown in Figs. 5.15 and 5.16, respectively. In these 
Table 5.5. Models Analyzed Thus Far in Study of Nozzles in Spheres with Triangular-Pad Reinforcing Under Internal Pressure Loading

\begin{tabular}{|c|c|c|c|}
\hline $\begin{array}{l}\text { Mode1 } \\
\text { No. }\end{array}$ & $D / T$ & $d / D$ & $\begin{array}{c}\alpha \\
\text { (deg) }\end{array}$ \\
\hline $\begin{array}{l}30-1 \\
60-1 \\
30-2 \\
30-3\end{array}$ & 10 & $\begin{array}{l}0.08 \\
0.08 \\
0.16 \\
0.32\end{array}$ & $\begin{array}{l}30 \\
60 \\
30 \\
30\end{array}$ \\
\hline $\begin{array}{l}30-5 \\
60-5 \\
30-6 \\
60-6 \\
30-7 \\
30-8\end{array}$ & 20 & $\begin{array}{l}0.04 \\
0.04 \\
0.08 \\
0.08 \\
0.16 \\
0.32\end{array}$ & $\begin{array}{l}30 \\
60 \\
30 \\
60 \\
30 \\
30\end{array}$ \\
\hline $\begin{array}{l}30-10 \\
60-10 \\
30-11 \\
60-11 \\
30-12 \\
60-12 \\
30-13 \\
30-14\end{array}$ & 40 & $\begin{array}{l}0.04 \\
0.04 \\
0.08 \\
0.08 \\
0.16 \\
0.16 \\
0.32 \\
0.50\end{array}$ & $\begin{array}{l}30 \\
60 \\
30 \\
60 \\
30 \\
60 \\
30 \\
30\end{array}$ \\
\hline $\begin{array}{l}30-15 \\
60-15 \\
30-16 \\
60-16 \\
30-17 \\
60-17 \\
30-18 \\
60-18 \\
30-19 \\
30-20\end{array}$ & 80 & $\begin{array}{l}0.02 \\
0.02 \\
0.04 \\
0.04 \\
0.08 \\
0.08 \\
0.16 \\
0.16 \\
0.32 \\
0.50\end{array}$ & $\begin{array}{l}30 \\
60 \\
30 \\
60 \\
30 \\
60 \\
30 \\
60 \\
30 \\
30\end{array}$ \\
\hline $\begin{array}{l}30-21 \\
60-21 \\
30-22 \\
60-22 \\
30-23 \\
60-23 \\
30-24 \\
60-24 \\
30-25 \\
30-26\end{array}$ & 160 & $\begin{array}{l}0.02 \\
0.02 \\
0.04 \\
0.04 \\
0.08 \\
0.08 \\
0.16 \\
0.16 \\
0.32 \\
0.50\end{array}$ & $\begin{array}{l}30 \\
60 \\
30 \\
60 \\
30 \\
60 \\
30 \\
60 \\
30 \\
30\end{array}$ \\
\hline $\begin{array}{l}30-27 \\
60-27 \\
30-28 \\
60-28 \\
30-29 \\
60-29\end{array}$ & 250 & $\begin{array}{l}0.01 \\
0.01 \\
0.02 \\
0.02 \\
0.04 \\
0.04\end{array}$ & $\begin{array}{l}30 \\
60 \\
30 \\
60 \\
30 \\
60\end{array}$ \\
\hline $\begin{array}{l}30-30 \\
60-30 \\
30-31 \\
60-31 \\
30-32 \\
30-33\end{array}$ & 250 & $\begin{array}{l}0.08 \\
0.08 \\
0.16 \\
0.16 \\
0.32 \\
0.50\end{array}$ & $\begin{array}{l}30 \\
60 \\
30 \\
30 \\
30 \\
30\end{array}$ \\
\hline
\end{tabular}


Table 5.6. Results of Finite Element Analysis of Reinforced Spherical Shell Models Having $D_{i} / T=24, d_{i} / D_{i}=0.2, d_{i} / T=11.45, s / S=1.0$

\begin{tabular}{|c|c|c|c|c|c|}
\hline Configuration & $\begin{array}{l}\text { Outside } \\
\text { Fillet } \\
\text { Radius }\end{array}$ & $\begin{array}{c}\text { Maximum } \\
\text { Normalized } \\
\text { Circumferential } \\
\text { Stress }\end{array}$ & $\begin{array}{c}\text { Maximum } \\
\text { Normalized } \\
\text { Meridional-P lane } \\
\text { Stress }\end{array}$ & $\begin{array}{l}\text { Maximum } \\
\text { Normalized } \\
\text { Stress } \\
\text { Intensity }\end{array}$ & Remarks \\
\hline$S-24 E$ & $4.35 T$ & 1.53 & 1.21 & 1.75 & $\begin{array}{l}\text { Model WN-10B with } 65 \% \text { out- } \\
\text { side fillet reinforcement } \\
\text { and } V=0.3\end{array}$ \\
\hline$S-24 E$ & $4.35 T$ & 1.96 & 1.72 & 1.96 & $\begin{array}{l}\text { Model wN-10B with } 65 \% \text { out- } \\
\text { side fillet reinforcement } \\
\text { and } v=0.49\end{array}$ \\
\hline$S-24 B$ & $1.56 T$ & 1.90 & 1.26 & 2.06 & $\begin{array}{l}10 \% \text { outside fillet rein- } \\
\text { forcement }\end{array}$ \\
\hline$S-24 G$ & $1.56 T$ & 1.64 & 2.04 & 2.04 & $\begin{array}{l}10 \% \text { outside reinforcement, } \\
90 \% \text { inside reinforcement }\end{array}$ \\
\hline$S-24 J$ & $3.31 T$ & 1.17 & 1.53 & 1.53 & $\begin{array}{l}44 \% \text { outside reinforcement, } \\
53 \% \text { inside reinforcement }\end{array}$ \\
\hline$S-24 K$ & $2.66 T$ & 1.28 & 1.68 & 1.68 & $\begin{array}{c}30 \% \text { outside reinforcement, } \\
71 \% \text { inside reinforcement }\end{array}$ \\
\hline$S-24 L$ & $6.00 T$ & 1.42 & 1.23 & 1.53 & $\begin{array}{l}118 \% \text { outside fillet rein- } \\
\text { forcement }\end{array}$ \\
\hline$S-24 M$ & $4.20 T$ & 1.24 & 1.31 & 1.40 & $\begin{array}{c}65 \% \text { outside reinforcement, } \\
40 \% \text { inside reinforcement }\end{array}$ \\
\hline
\end{tabular}



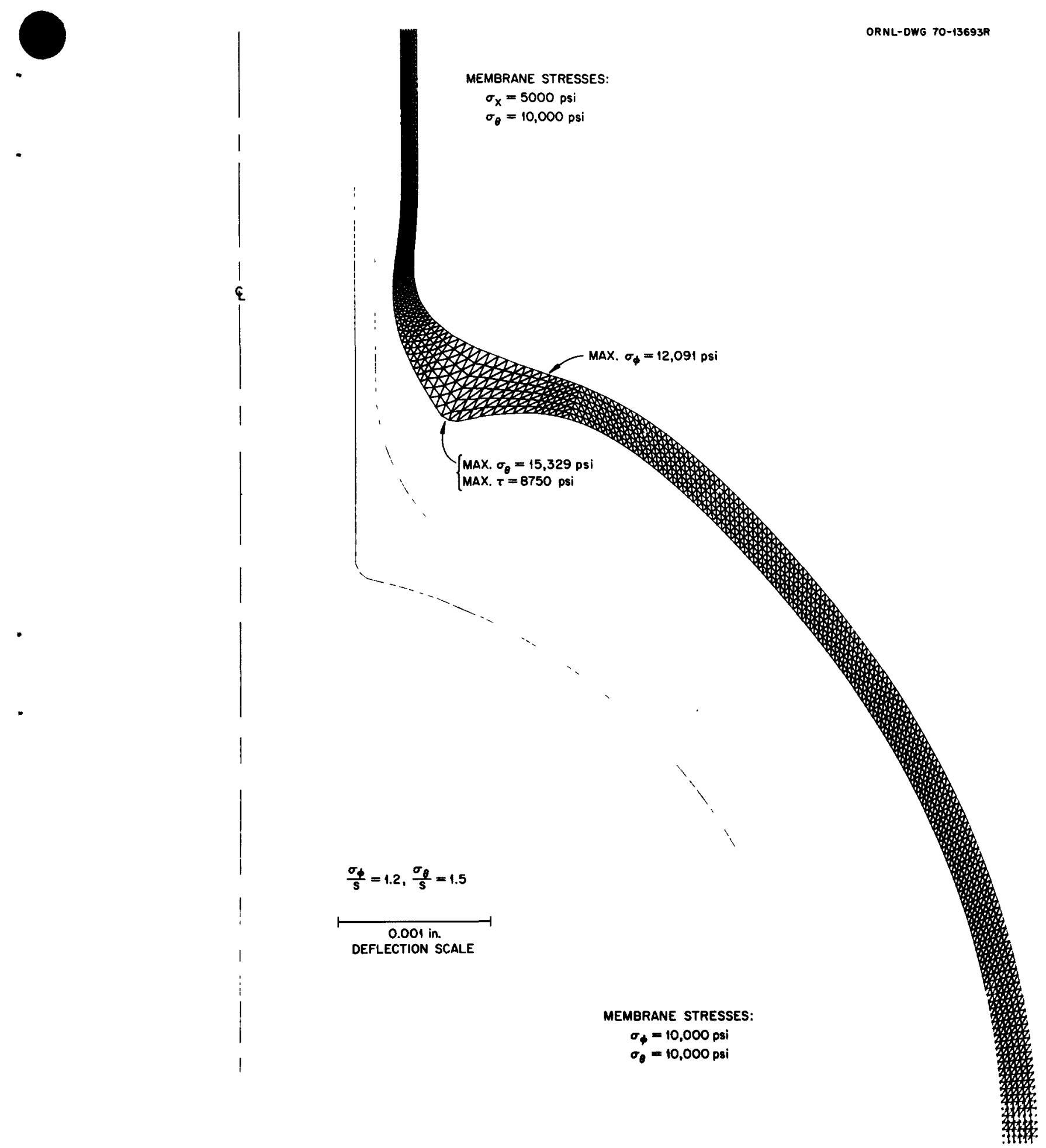

Fig. 5.15. Disp1aced Configuration for Model S-24E, with $\nu=0.30$ and $65 \%$ Outside Fillet Reinforcement. 


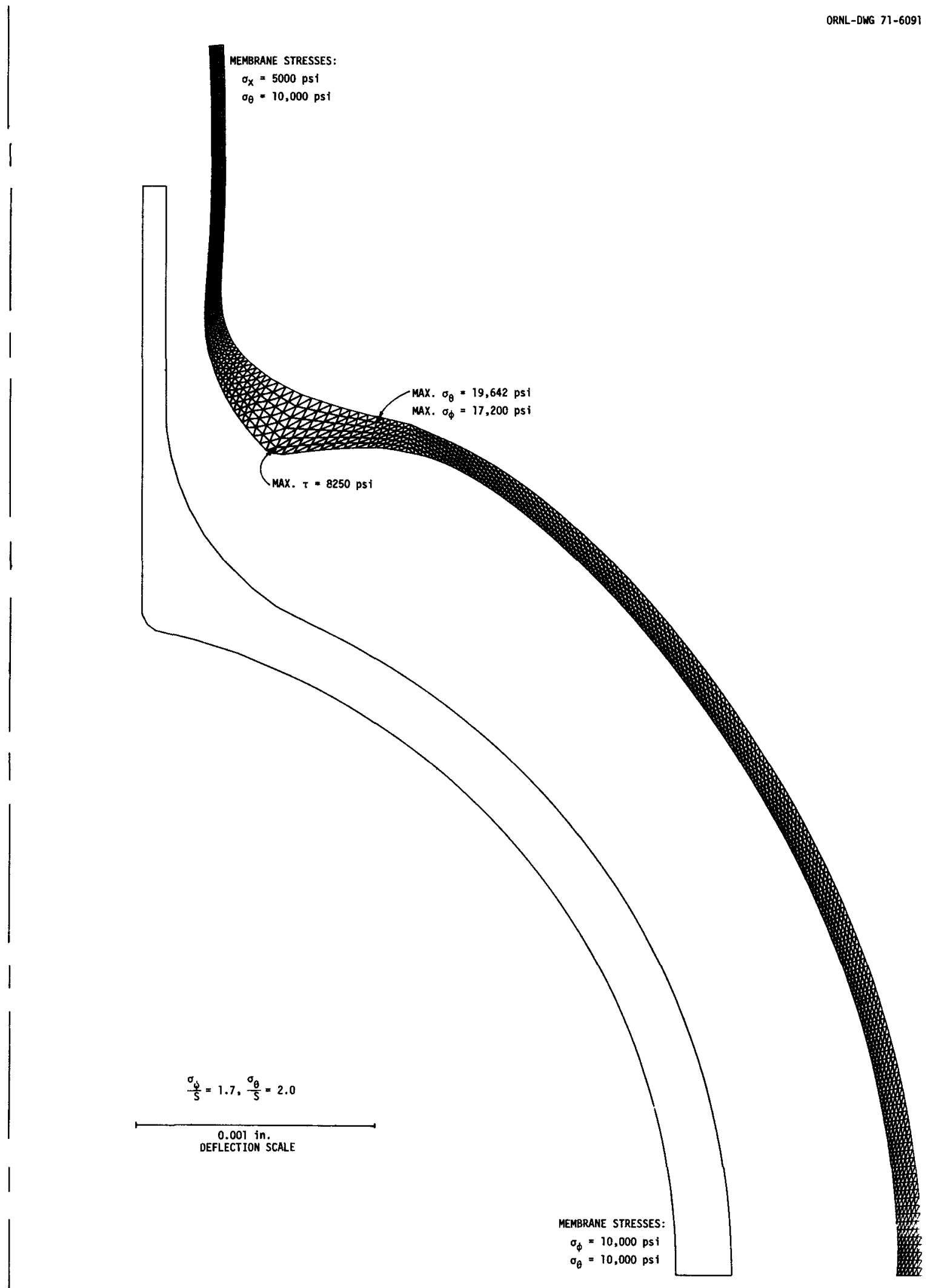

Fig. 5.16. Displaced Configuration for Mode1 S24E, with $v:=0.49$ and 65\% Outside Fillet Reinforcement. 
figures, $\sigma_{\theta}$ is the circumferential stress and $\sigma_{\phi}$ is the meridional stress. It should be emphasized that the deformed models shown in the figures to the right of the undeformed cross sections are gross exaggerations of the actual deformation and are intended to indicate the mode of deformation. In the case of the two analyses of model S-24E, the stress intensity was $12 \%$ higher when the Poisson's ratio was increased from 0.3 to 0.49 . The results of these additional analyses are being used for code-rule development work in progress at Battelle Memorial Institute.

\section{References}

1. M. M. Leven, Stress Distribution at Two Closely-Spaced Reinforced Openings in a Pressurized Cylinder, Research Report 71-9E7-PHOTO-R1, Westinghouse Research Laboratories, Apr. 9, 1971.

2. M. M. Leven, Photoelastic Determination of the Stresses in Reinforced Openings in Pressure Vessels, Welding Research Council Bulletin No. 113, April 1966.

3. C. Ling, On the Stresses in a Plate Containing Two Circular Holes, J. App Z. Phys., pp. 77-82, January 1948. 
$\bullet$

•

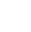

. 
6. RDT STANDARDS PROGRAM

M. Bender, Project Director

\subsection{PROGRAM OBJECTIVES AND ACTIVITIES}

(AEC Activity $04 \quad 608003 \quad 1$ )

W. F. Ferguson R. A. Schmidt

Current activities include (1) working cooperatively with projects under the direction of RDT in application of standards; (2) analyzing RDT project needs for standards; (3) reviewing and providing advisory services on standards prepared by other participating projects and organizations; (4) preparing and distributing new standards and reviewing and updating existing standards; (5) maintaining close liaison with the LMEC Standards Office; (6) planning and developing program schedules, goals, and details; (7) writing and distributing reports, indexes, and tabulations pertaining to the program; (8) participating in committee and task group activities of recognized voluntary codes and standards agencies; (9) preparing guidelines for format, definitions, titling, and numbering; (10) analyzing and preparing periodic summaries of RDT incident reports; (11) consulting with reactor designers, builders, operators, AEC agencies, and contractors; (12) collecting and analyzing reports of reactor experience and technical data; and (13) directing and reviewing the participation of subcontractors and engineering consultants in the standards program. 


\section{Organization, Scheduling, and Manpower}

The existing manpower and subcontract estimates were reviewed and adjusted, and the schedules and assistance requirements for projects under way were adjusted to meet current needs. The revised Budget and Program Proposal, Form 189a, for the remainder of the fiscal year and subsequent years was prepared and submitted to the Nuclear Safety Program Office for inclusion in the proposed budget for the Nuclear Safety Program.

Increased effort was directed toward expediting assistance in preparing draft standards and evaluating fabrication and procurement problems encountered in current projects; providing review of standards being prepared by others; and summarizing documentation of review comments received by ORNL. Subcontract work at Franklin Institute Research Laboratories (FIRL), MPR Associates, and Teledyne Materials Research (TMR) was reexamined in preparation for completion of assigned tasks.

\section{Activities}

The ORNL proposal to identify and publish "Engineering Technology References" (technical support documents that provide information and guidelines to assist users of RDT standards) was accepted by RDT. At the request of $\mathrm{RDT}$, publication of ETR-1, Quality Assurance Program Guidelines and Practices was deferred until experience in implementing the quality assurance requirements of RDT F 2-2T has been gained. The draft of ETR-2, Nuclear Piping Design, which was originally prepared as RDT E 7-1, was sent to RDT for information and circulated for comment and is now being edited at ORNL. In addition to ETR-1 and ETR-2, the following documents are currently proposed for issue as Engineering Technology References:

Glossary of Terms in Nuclear Technology (Supplement to ANSI N1.1)

Cleaning and Cleanliness Control - Recommended Practices

Interim Structural Design Criteria for Elevated Temperatures (HEDL)

Pump Design Guide for Water-Cooled Reactors

Heat Transfer Equipment Design Guide for Water-Cooled Reactors Structural Design of Water-Cooled Reactor Internals 
Selection and Procurement of Nuclear Pressure-Relief Valves Rupture Disc Assembly Design Guide for Water-Cooled Reactors Water Reactor Coolant-Recirculating Pump Evaluation Guide Selection of Waler Reactor Coolant Pump Functional and Design Requirements

Selection of Steam Generator Functional Requirements and Ordering Data for Pressurized-Water Reactors

Evaluation of the Design and Fabrication of Steam Generators for Pressurized-Water Reactors

Technical Evaluation of Steam Generator and Reactor Coolant Pump Suppliers for Water-Cooled Reactors

Sodium Practices and Procedures (LMEC)

Guide for Specifying Valves for Water-Cooled ivuclear Reactors

Engineering Practices for Large (4 Inches and Over) Gate, Globe, and Check Valves in Water-Cooled Nuclear Reactors

Static Seals and Their Application in Water-Cooled Nuclear Reactors

An Interpretive Review of Seismic Design Methods

Interaction of a Seismic Disturbance with a Nuclear Reactor Facility

Survey of Nuclear Reactor System Primary Circuit Heat Exchanger Tube Vibration

Proposed changes to RDT F 1-1, Preparation of RDT Standards, and recommendations for the proposed supplementary document to cover the application and use of RDT standards were submitted to RDT.

Following an inquiry from RDT on modifications to RDT F 7-2, Preparations for Sealing, Packaging, Packing, and Marking of Components for Shipment and Storage, ORNL submitted a proposal that this standard be revised and updated to current standards. RDT F 7-2 was issued over two years ago by changing only the number on an older specification, and it has not been revised for ten or more years. It was also proposed by ORNL that the users of this standard prepare a modification document to cover the specific points of concern for their immediate applications.

RDT requested that the ORNL and LMEC Responsible Standards Offices continue to publish separate status reports in accordance with present schedules. The proposal for the combined ORNL-LMEC quarterly status 
report will be reviewed during the forthcoming management meeting to be held at LMEC.

With the intent to more efficiently handle the printing and distribution of standards, ORNL and LMEC are studying the feasibility of establishing a central distribution agency that would be supported and used by all RDT contractors responsible for preparing and issuing RDT standards. Such an agency would eliminate the need for multiple reproduction, packaging, and mailing points with attendant handling and communication problems and should result in simplifying the mechanics and cost of publishing and disseminating approved standards.

Work continued on the development and preparation of a Glossary of Engineering Terms in Nuclear Technology for the Standards Program.

ORNL was requested to participate in evaluating the identification and effect of defects resulting from the welding technique being used on portions of the FFTF reactor vessel. A meeting was attended at Combustion Engineering to observe and discuss the welding and the examination. The findings and analysis resulting from this meeting will be forwarded to HEDL.

Representatives from the Standards Office continued participation in ANS-7, Subcomittee on Reactor Component Criteria; ANS 11.13, Concrete Radiation Shields; ASTM A-10, Subcommittee IV-408, Stainless Steel Corrosion; ASTM C-16, Committee on Thermal Insulation; ANSI Nuclear Technical Advisory Board; ANSI N45-3.0, Subcommittee on Nuclear Quality Assurance Standards, and N45 Ad Hoc Committees 3.1, 3.2, 3.3, 3.4, 3.5, 3.6, 3.7, and 3.8; and ASME Botler and Pressure Vessel Working Groups on Core Support Structures (SC-III) and Quality Assurance and Stamping (SC-III).

Considerable effort was expended in assisting in the preparation of the ANSI-N45 standards related to the construction phase of nuclear power plants.

\section{Status of Standards Being Processed}

The following approved tentative standards were issued:

Issued By

C 6-1T NaK Transmission - High-Temperature PresLMEC sure Transmitter for Liquid-Metal Service 
Issued By

C 15-2T Wide-Range (10-Decade) Neutron-Flux-

ANL Monitoring Channel

E 1-18T Class I Valves for Liquid-Metal Service

LMEC

E 3-9T Electromagnetic Pump for Liquid-Meta1

AI Service

The following documents were approved by RDT and will c issued as tentative standards at a future date:

E 2-1 Requirements for Nuclear Vessels (Supplement to ASME Boiler and Pressure Vesse1 Code, Section III)

F 6-5 Welding Qualification Requirements (Supplement to ASME Boiler and Pressure Vessel Code, Section IX)

The following standard was prepared by ORNL and submitted to RDT for approval:

C 15-3 Currnnt Pulse Preamplifiers for Use with Fission Counters

The following standards were prepared and submitted to INC for approval through the LOFT project:

E 1-6 Automatic Spring-Loaded Safety Valves

E 1-12 Stainless Steel Check Valves

E 1 - 14 Power-Actuated Pressure-Relief Valves

E 1-23 Stainless Steel Throttling Valves, Manual or Power Operated

E 3-7 Reciprocating Positive-Displacement Pump

M 12-4 Reflective Insulation

RDT numbers were assigned to 39 new standards:

*A 1-5 Purity Specifications for Large Operating Sodium System

*C 8-5 Electrochemical Oxygen Meter for Sodium Service

*C 8-6 Hydrogen Activity Meter for Sodium Service

*C 8-7 Diffusion-Type Carbon Meter for Sodium Service

*C 8-8 Equilibration Device for Measuring Nonmetallic Impurity Activities in Sodium

*C 8-9 $\mathrm{H}_{2}$ Detection for Sodium-Water Reactions

*C 14-1 Containment-Exhaust Radiation-Monitoring Equipment

*LMEC is Resdonsible Standards Office. 

*C 16-2 FFTF Solid-State Protection System Logic
*C 17-6 FFTF Cable for Nuclear-Radiation Detectors
*E 4-19 Plugging Temperature-Indicator Assembly for Sodium Services
*E 8-13 0-H Meter Module for Sodium Service Carbon Meter
*E 8-14 Equilibration Device Module for Sodium Service
*E 10-5 FFTF Containment Vessel Air-Lock Bellows
E 15-2 Requirements for Nuclear Components (Supplement to ASME Boiler and Pressure Vessel Code, Sec- tion III)
F 3-32 Acceptance and Operational Testing Requirements for High-Efficiency Air-Cleaning Systems
F 3-33 In-Place Testing of High-Efficiency Gas-Phase Adsorber Systems Using Radioactive Iodine Tracer
M 2-14 Copper and Copper Alloy Forgings (ASTM B283 with Additional Requirements)
M 2-15 Bars, Forgings, and Rings, 1950F Solution-Treated (Inconel 718) (AMS 5664 with Additional Require- ments)

M 3-21 Copper and Copper Alloy Seamless Tubes (ASTM B111 with Additional Requirements)

M 3-22 Copper Seamless Pipe (ASTM B42 with Additiona1 Requirements)

M 3-23 Copper-Nickel Seamless Pipe and Tube (ASTM B466 with Additional Requirements)

M 3-24 Nicke1-Copper Alloy Seamless Pipe and Tube (ASTM B165 with Additional Requirements

M 3-25 Nickel Pipe and Tube (ASTM B161 with Additional Requirements)

*M 3-26 Finned Austenitic Stainless Steel Tubes (ASTM A498 with Additional Requirements)

M 3-27 Seamless and Welded Small Diameter Austenitic Stainless Steel Tubing (ASTM A632 with Additional Requirements)

M 4-7 Copper-Nickel Alloy Castings (ASTM B369 with Additional Requirements)

M 5-11 Copper Sheet, Strip, Plate and Rolled Bar (ASTM B152 with Additional Requirements)

*LMEC is Responsible Standards Office. 


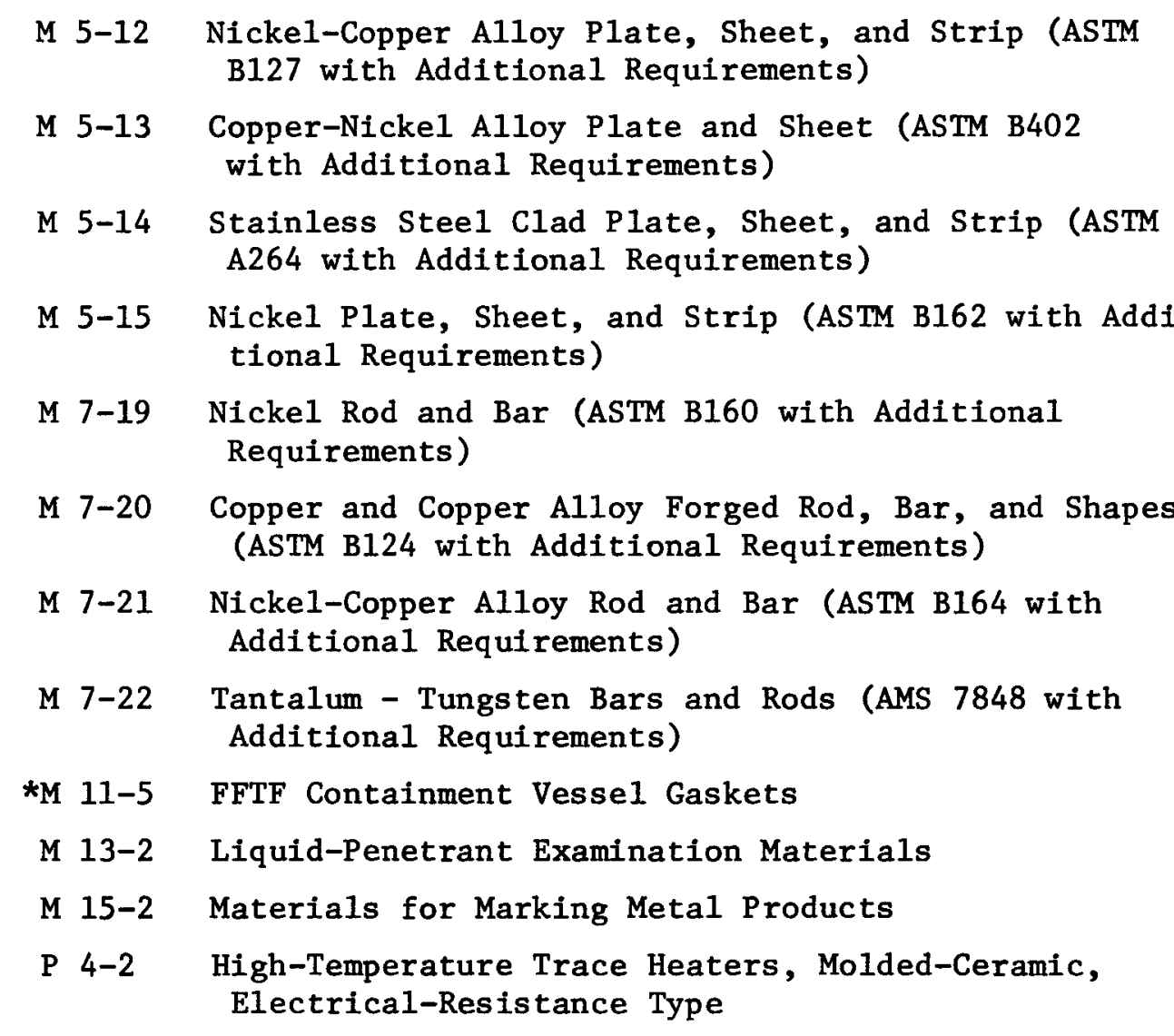

RDT C 8-1, Manufacturing Requirements for a Sodium Plugging Meter, and C 8-3, Design Criteria for Sodium Plugging Meter, were canceled. LMEC was the Responsible Standards Office for both standards.

RDT M 16-2 was deleted and will be combined with M 16-1, Activated Carbon for Gas-Phase Iodine Adsorption. Titles of the following standards were changed:

E 9-3 High Efficiency Gas-Phase Adsorber Cells, Pleated Bed

**E 13-14 Fuel Pins for Pressurized-Water Reactors

F 3-34 In-Place DOP Testing of High-Efficiency Air Filter Systems

F 3-35 In-Place Testing of High-Efficiency Gas-Phase Adsorber Systems Using Refrigerant-112

M 16-1 Activated Carbon for Gas-Phase Iodine Adsorption

Considerable effort was expended on the continuing activities of reviewing and commenting on draft standards prepared by others and of

*LMEC is Responsible Standards Office

**For LOFT Project. 
evaluating comments received from outside reviewers on drafts prepared by ORNL.

The following drafts were reviewed by ORNL, and comments were prepared and submitted to the requester:

C 4-5 Permanent Magnet Flowmeter for Liquid-Metal

(Rev 1) Service

C 15-5 Low-Level Fission-Type Neutron Detector

E 7-3 Heat Transport Piping Systems for Liquid-

Metal Fast Breeder Reactors

The comments received on the following documents were evaluated for incorporation into the standards:

E 4-17 Heat Exchanger, Class C, Water-to-Water, Straight or U-Tube

F 3-6T Nondestructive Examination

F 3-37 Special Requirements for Metal Products

M 1-7T Copper and Copper Alloy Welding Electrodes

(ASTM B225 with Additional Requirements)

M 1-10T Nickel and Nickel-Alloy-Covered Welding

Electrodes (ASTM B295 with Additional

Requirements)

M 1-11T Nickel and Nickel-Alloy Bare Welding Rods and Electrodes (ASTM B304 with Additional Requirements)

M 3-4T Nickel Alloy Seamless Tubes (ASTM B163 with Additiona1 Requirements)

M 3-9 Nicke1-Iron-Chromium Alloy Seamless Pipe and Tubing (ASTM B407 with Additional Requirements)

M 5-4T Ni-Cr-Fe Alloy Plate, Sheet, and Strip (ASTM B168 with Additional Requirements)

M 5-7 Ni-Fe-Cr Alloy Plate, Sheet, and Strip (ASTM B409 with Additional Requirements)

M 7-2T Nickel Alloy Bar, Rod, and Forgings, Precipitation Hardening (ASTM A461 with Additional Requirements)

M 7-4T Ni-Cr-Fe Alloy Rod, Bar, and Forgings (ASTM B166 with Additional Requirements)

M 7-10 Nicke1-Iron-Chromium Alloy Rod, Bars, and Forgings (ASTM B408 with Additional Requirements) 
M 12-3 Chloride-Corrosion-Inhibiting Mineral Fiber, Hydraulic-Setting Insulating and Finishing Cement (ASTM C449 with Additiona1 Requirements)

M 12-4 Reflective Insulation

The comments received on the following documents were incorporated into the standards:

E 1-6 Automatic Spring-Loaded Safety Valves

E 1-23 Stainless Steel Thrott1ing Valves, Manual or Power Operated

E 2-1 Requirements for Nuclear Vessels (Supplement to ASME Boiler and Pressure Vesse1

Code, Section III)

F 6-5 Welding Qualification Requirements (Supplement to ASME Boiler and Pressure Vessel Code, Section IX)

In-house review of $\mathrm{P} 2-3$, Criteria and Requirements for Class IE Electrical System, is in progress.

ORNL completed in-house review of the following standards:

C 15-3 Current Pulse Preamplifiers for Use with Fission Counters

E 9-4 Single Filter Housing for HEPA Filter

E 15-1 Containment Spray Systems

M 5-10 Glass for Viewing Windows for Use in Glove Boxes

Drafts of the following documents were distributed for external review and comments:

C 7-5 Thermocouple Material, Chrome1-P vs Alume1, Magnesium Oxide Insulated, Stainless Steel Sheathed

E 11-1 Demineralizer, Mixed-Bed Nonregenerative Type

M 3-20 Polyethylene Tubing

\section{Summary of Status of Standards Program}

The tentative standards currently available for use now number 106, and 104 draft standards are awaiting approval by RDT. The ORNL mailing list for tentative standards now contains 285 addressees, including AEC installations and contractors, codes and standards organizations, 
architect-engineers, consultants, nuclear component manufacturers, and electrical utilities, who receive a total of 528 copies.

In response to telephone and memo requests, 578 copies of RDT standards and 10 copies of the index of standards were mailed to 53 organizations, three of which were added to the distribution list to receive future issues of the standards or the quarterly index.

\subsection{REACTOR COOLANT SYSTEM AND EQUIPMENT STANDARDS}

(AEC Activity 04608003 1)

$\begin{array}{ll}\text { H. G. Arnold } & \text { D. L. Gray } \\ \text { W. A. Bush } & \text { J. M. O'Keefe } \\ \text { R. W. Dehoney } & \text { L. F. Pars ly } \\ \text { W. R. Gall } & \text { T. H. Row }\end{array}$

Piping, Valves, and Rupture Discs

The comments received from RDT were incorporated into E 1-6, Automatic Spring-Loaded Safety Valves, and E 1-23, Stainless Steel Throttling Valves, Manual or Power Operated. Both documents were transmitted to INC for use on the LOFT project.

At the request of HEDL, ORNL will prepare valve standards for the FFTF containment vessel and cover gas system.

A document that will invoke design rules for Class I valves of 4-in. nominal size and less is being prepared by TMR.

The draft of ETR-2, Nuclear Piping Design, which was originally prepared as RDT E 7-1, was sent to RDT for information and is now being edited at ORNL for publication as an Engineering Technology Reference.

\section{$\underline{\text { Pumps }}$}

The computer card deck that covers the mesh generator program for the full pump casing to be used with the copaTs computer program for stress analyzing complex pump casings was received from FIRL. Trial runs on the mesh generator and the mesh plotting programs will begin at 
ORNL on the 360/91 computer in May. A discussion paper on the COPATS program was presented by FIRL at the April Information Meeting on Applied Solid Mechanics.

The advanced draft of RDT E 3-7, Reciprocating Positive Displacement Pump, was completed and transmitted to INC. This standard will be used in the procurement of the primary coolant addition pumps, and RDT approval will be processed through LOFT app1ication.

The revised edition of the "Design Evaluation Guide - Primary Coo1ant Pumps for Water-Cooled Reactors" was received from FIRL. This document will be edited by ORNL and issued as an RDT Engineering Technology Reference.

\section{$\underline{\text { Static Seals }}$}

The document, Static Seals and Their Application in Water-Cooled Nuclear Reactor Systems, was issued as ORNL-TM-3308. A paper based on this document will be presented by FIRL personnel at the annual meeting of the American Society of Lubrication Engineers, and ORNL has submitted an invited discussion on the paper.

Work will resume during the next period on the drafts of the six static seal standards that were prepared by FIRL and submitted to ORNL.

\section{Heat Exchangers}

The information document, Heat Transfer Equipment Design (E 4-3), is awaiting final editing prior to being prepared and issued as an Engineering Technology Reference.

\section{Nuclear Code Supplements}

The following code-supplement standards were approved by RDT and are now ready to be printed. At the request of $\mathrm{RDT}$, printing and distribution as tentative standards were delayed to await approval of other standards referenced within these documents:

E 2-1 Requirements for Nuclear Vessels (Supplement to ASME Boiler and Pressure Vessel Code, Section III) 
E 3-10 Requirements for Nuclear Pumps and Valves (Supplement to ASME Code for Pumps and Valves for Nuclear Service)

E 7-5 Requirements for Nuclear Piping (Supplement to ANSI Standard B31.7, Nuclear Power Piping)

F 6-5 Welding Qualification Requirements (Supplement to ASME Boiler and Pressure Vessel Code, Section IX)

To supplement the 1971 edition of Section III, which now includes piping, pumps, valves, and vessels, RDT standards E 2-1, E 3-10, and E 7-5 will be revised and combined into a single document, E 15-2, Requirements for Nuclear Components (Supplement to ASME Section III).

\section{Demineralizers}

A preliminary draft of RDT E 11-1, Demineralizer, Mixed-Bed, NonRegenerative Type, was completed and distributed for review and comments.

\section{$\underline{\text { Radioactive Waste Systems }}$}

A proposal for a standard covering radioactive waste systems is being prepared for RDT consideration.

\section{Containment Spray Systems}

The comments received from the preliminary review of $E 15-1$, Containment Spray Systems, were reconciled, and the standard was prepared for formal distribution for review and comments. This standard provides both a guide for process design of spray systems and requirements for mechanical design, installation, and testing of components and the system. 


\subsection{INSTRUMENTATION, CONTROLS, AND ELECTRICAL EQUIPMENT STANDARDS}

(AEC Activity 04608003 1)
R. K. Abele
T. L. Hudson
A. E. G. Bates
0. A. Kelly
J. T. DeLorenzo
C. S. Lisser
T. M. Gayle
J. A. Russe11

\section{Instrumentation}

A meeting was attended at RDT to discuss instrument standards for the FFTF with representatives of RDT-I\&C, HEDL, WARD, and Bechtel. ORNL was requested to consider preparing three instrument standards for this project: (1) a signal conditioner for chromel vs alumel thermocouples, (2) a containment system pressure-measuring device, and (3) grounding and shielding instruments.

RDT C 7-5, Thermocouple Material, Chrome1-P vs Alume1, MagnesiumOxide Insulated Stainless Steel Sheathed, was distributed for external review and comments.

RDT C 15-3, Current Pulse Preamplifiers for Use with Fission Counters, was submitted to RDT for approval.

The ORNL review of C 15-5, Low-Leve1 Fission-Type Neutron Detector, was completed, and comments were consolidated and submitted to HEDL.

RDT C 4-5 (Rev, 1), Permanent Magnet Flowmeter for Liquid Metal Service, was reviewed by ORNL, and comments were submitted to LMEC.

RDT C 7-15, Thermocouple Connectors and Thermocouple Patch Panels, and C 7-16, Thermocouple Assembly, Stainless Steel Sheathed, Magnesium Oxide Insulated, were revised following preliminary review.

RDT C 2-3, Time Response Testing of Thermocouples, was prepared and is ready to be distributed for review and comments. The preliminary draft of C 7-7, Thermocouple Material, Platinum and 90\% Platinum-10\% Rhodium, was prepared, and work is in progress on RDT C 4-3, Orifice Flanges. 


\section{Electrical}

RDT P 4-2, High-Temperature Trace Heaters, Molded Ceramic ElectricResistance Type, is being prepared for procurement of heaters formerly included in the initial draft of $M$ 12-4, Reflective Insulation.

Revision of P 2-3, Criteria and Requirements for Class IE Electrical System, to incorporate comments received during in-house review was delayed because of higher priority work.

\subsection{PROGRAMMATIC AND PROCEDURAL STANDARDS \\ (AEC Activity 04608003 1) \\ J. W. Anderson F. L. Hannon \\ H. G. Arnold R. M. Holmes \\ C. A. Burchsted T. W. Pickel \\ N. E. Dunwoody W. C. T. Stoddart}

J. A. Woodley

\section{Quality Assurance}

Implementation of RDT Standards F 2-2T, Quality Assurance Program Requirements, and F 2-4T, Quality Verification Program Requirements; nondestructive examination techniques; and future activities of the Quality Assurance Working Group were discussed in a recent meeting of the group. As directed by $\mathrm{RDT}$, the working group is to be disbanded, and any future meetings involving the members of the group will be to discuss specific items of mutual interest.

At the request of $\mathrm{RDT}$, the publication of ETR-1, Quality Assurance Program Guidelines and Practices, was deferred until experience has been gained in implementing the quality assurance requirements of RDT F 2-2T.

\section{Maintenance}

An internal review was made and a revised draft of RDT F 4-20, Operations and Maintenance Manuals, is being prepared in accordance with 
agreements reached with $\mathrm{RDT}$ on the ORNL proposal to reorganize this document.

\section{$\underline{\text { Seismic Design }}$}

A preliminary draft of the standard for seismic design of nuclear power plants was completed and is currently being reviewed at ORNL. After receipt of comments from this review, a revised draft will be submitted to RDT for review.

\section{Air Cleaning}

RDT E 9-4, Single Filter Housing for HEPA Filter, was reviewed inhouse, and comments are being incorporated into a revised draft prior to transmittal for external review and comments.

\subsection{MATERIALS AND FABRICATION STANDARDS \\ (AEC Activity 04608003 1) \\ J. W. Anderson F. L. Hannon \\ R. O. Carden O. A. Ke11y \\ R. M. Fuller J. N. Robinson}

J. A. Woodley

RDT M 12-4, Reflective Insulation, was rewritten and transmitted to INC for use on the LOFT project. Review comments now being received on this standard are being evaluated for incorporation in a future revision of the document.

The comments received on RDT M 12-3, Chloride Corrosion Inhibiting Mineral Fiber, Hydraulic-Setting Insulating and Finishing Cement (ASTM C449 with Additional Requirements), are being evaluated for incorporation into the standard.

RDT M 5-10, Glass for Viewing Windows for Use in Glove Boxes, was reviewed in-house, and comments are being incorporated into a revised draft prior to transmittal for external review and comments. 
In compliance with a request from HEDL, RDT M 3-26, Finned Austenitic Stainless Steel Tubes (ASTM A498 with Additional Requirements), was prepared for FFTF application.

RDT M 3-20, Polyethylene Tubing, was distributed for external review and comments. 
7. GENERAL NUCLEAR SAFETY STUDIES

\subsection{HTGR SAFETY PROGRAM OFFICE}

(AEC Activity 04607001 1)

S. I. Kaplan W. E. Browning, Jr.

The HTGR Safety Program Office (HTGR-SPO) observes and evaluates research that contributes to the safety of high-temperature gas-cooled reactors (HTGRs) and prepares analyses and recommendations on this topic for the guidance of the AEC Division of Reactor Development and Technology (DRDT). It also is responsible for preparing a long-range plan for the HTGR safety program.

The HTGR-SPO is continuing its review of pertinent source material in the course of revising the preliminary issue of the HTGR safety program plan. A meeting will be held with representatives of Gulf General Atomic in early May to assure that the plan's basic assumptions reflect current HTGR design and technology.

A draft of a paper entitled "Safety Research and High-Temperature Gas-Cooled Reactor Design" was prepared for Volume 12, Issue 5, of $\mathrm{Nu}$ clear safety, which will be distributed at the 1971 Geneva Conference. This article was prepared at DRDT's request and circulated for review. Following review the final draft was completed and submitted to the $\mathrm{Nu}$ clear safety staff. 


\subsection{IGNITION OF CHARCOAL ADSORBERS BY FISSION-PRODUCT DECAY HEAT}

(AEC Activity 024020 90)

\section{R. A. Lorenz R. P. Shields}

An experiment was designed for demonstrating the consequences of heat generation in a charcoal bed from radioactive decay of adsorbed iodine. The experiment will involve preparation of ${ }^{130} \mathrm{I}$ by irradiation in HFIR of ${ }^{129} \mathrm{I}$ as $\mathrm{PdI}_{2}$, release of the ${ }^{130} \mathrm{I}$ as $\mathrm{I}_{2}$ by heating the $\mathrm{PdI}_{2}$, transfer of the $I_{2}$ to an instrumented charcoal test bed, and observation of bed temperatures and location of adsorbed iodine during experiments with low air flow.

Components of the insulated charcoal bed, which has been constructed, are shown in Fig. 7.1. This picture may be compared with a previously published schematic drawing. ${ }^{1}$ Eight thermocouples will pass through holes in the bottom support plate to monitor temperatures in and around the charcoal bed inside the Dewar flask. The thermocouple access holes will be sealed, Fiberfrax insulation disks will be placed between the cup and support plate, the charcoal will be loaded to a 2-in. depth, and springloaded clips will hold the insulating flask in position. The aluminum jacket around the top portion of the Dewar flask may be heated to follow the temperature of the charcoal bed, if necessary, to minimize radial heat losses.

The stainless steel charcoal casing and entrance tube, as well as the inner wall of the Dewar flask, were purposely made thin to minimize the axial flow of heat by conduction, since this mode of heat flow would not be typical of an adsorber tray in a stacked array. The faces of stacked trays would be facing identical faces of other trays so that no net axial heat transport should occur as a result of conduction or radiation heat transfer, at least in the inner 50 to $60 \%$ of tray face area. ${ }^{2}$ The use of thin components inside the Dewar also minimizes heat capacity that detracts from the expected heatup rate for charcoal.

A small calibrated electric heater in a glass-wool matrix is to be used as a substitute for radioiodine on charcoal in determinations of the calorimetric characteristics of the apparatus; that is, the heat 


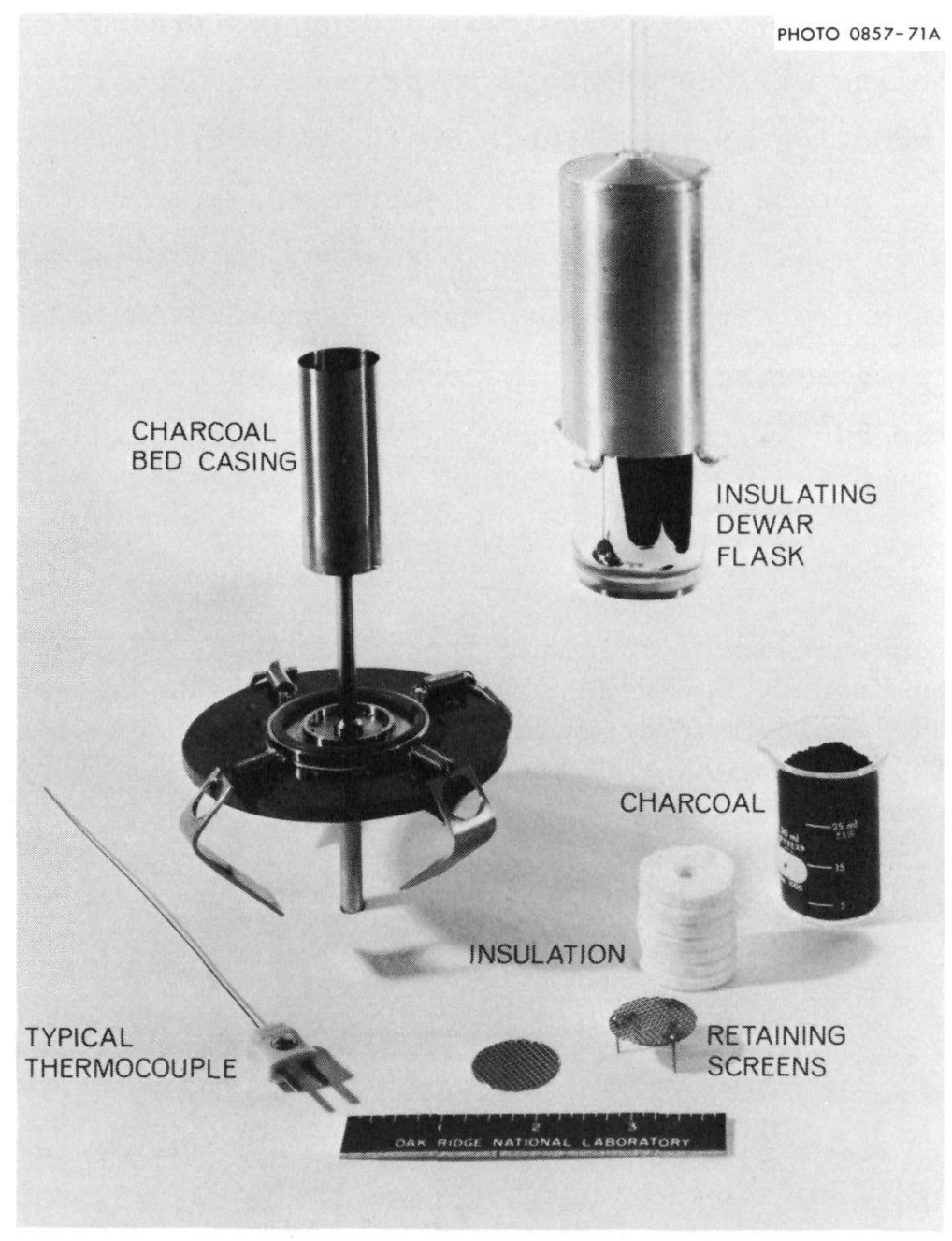

Fig. 7.1. Components of Insulated Charcoal Bed for Determining the Effects of Highly Radioactive Iodine on Charcoal Ignition.

capacity of the components inside the Dewar flask and the radial and axial heat 1osses. Demonstrations that normal ignition temperatures can be measured with the apparatus and that the resulting fire can be extinguished without damage to the equipment are planned.

Calculations and experiments were both used to show that the irradiation of ${ }^{129} \mathrm{I}$ as $\mathrm{PdI}_{2}$ in HFIR can be performed in a safe manner. Heat transfer calculations which indicate safe irradiation temperatures in the reactor, were verified by the HFIR experiment review staff. Experiments were performed with a calibrated electric heater inside a mockup irradiation capsule to verify adequate dispersal of decay heat after removal of 
the capsule from the water-cooled HFIR hydraulic irradiation tube. Natural convection cooling will be adequate to prevent decomposition of $\mathrm{PdI}_{2}$ during shipping and handling of the capsule in the hot cell. The compound decomposes at $350^{\circ} \mathrm{C}$, but $12 \mathrm{~W}$ of heat is required to raise the capsule temperature to $260^{\circ} \mathrm{C}$ in open air, $275^{\circ} \mathrm{C}$ while resting on a flat surface, and $300^{\circ} \mathrm{C}$ while in a dry shipping container.

Work is progressing on the development of procedures for preparing and loading the $\mathrm{Pd}^{129} \mathrm{I}_{2}$ in the capsule for the HFIR irradiation.

\section{References}

1. R. A. Lorenz and R. P. Shields, The Ignition of Charcoal Adsorbers by Fission-Product Decay Heat, pp. 118-119, ORNL Nuclear Safety Research and Development Program Bimonthly Report for January-February 1971, USAEC Report ORNL-TM-3342, Oak Ridge National Laboratory, 1971.

2. R. P. Shields and M. Siman-Tov, The Effect of Iodine Decay Heat on Charcoal Adsorbers, USAEC Report ORNL-4602, pp. 3-7, Oak Ridge National Laboratory, 1971.

\subsection{EFFECT OF VELOCITY ON EFFICIENCY OF ABSOLUTE FILTER MEDIA FOR REMOVAL OF STAINLESS STEEL-UO 2 AEROSOL}

(AEC Activity 03402090 )

\section{J. Truitt}

A study is being made of the effect of velocity on efficiency of commercial high-efficiency filter media for the removal of aerosol particles of the kind anticipated in reactor accidents. The aerosol being studied consists of agglomerates of nuclei of $\mathrm{UO}_{2}$ and the oxides of stainless steel. The aerosol generation method and the filter testing system were described previous1y. ${ }^{1}$

The normalized particle size distribution of the test aerosol is shown in Fig. 7.2 in terms of particle number concentration. By particle size distribution is meant the incremental change in number concentration with particle radius; that is, $d N / d r$. By "normalized size distribution" is meant the size distribution divided by the number concentration; that 
ORNL-DWG 71-6092

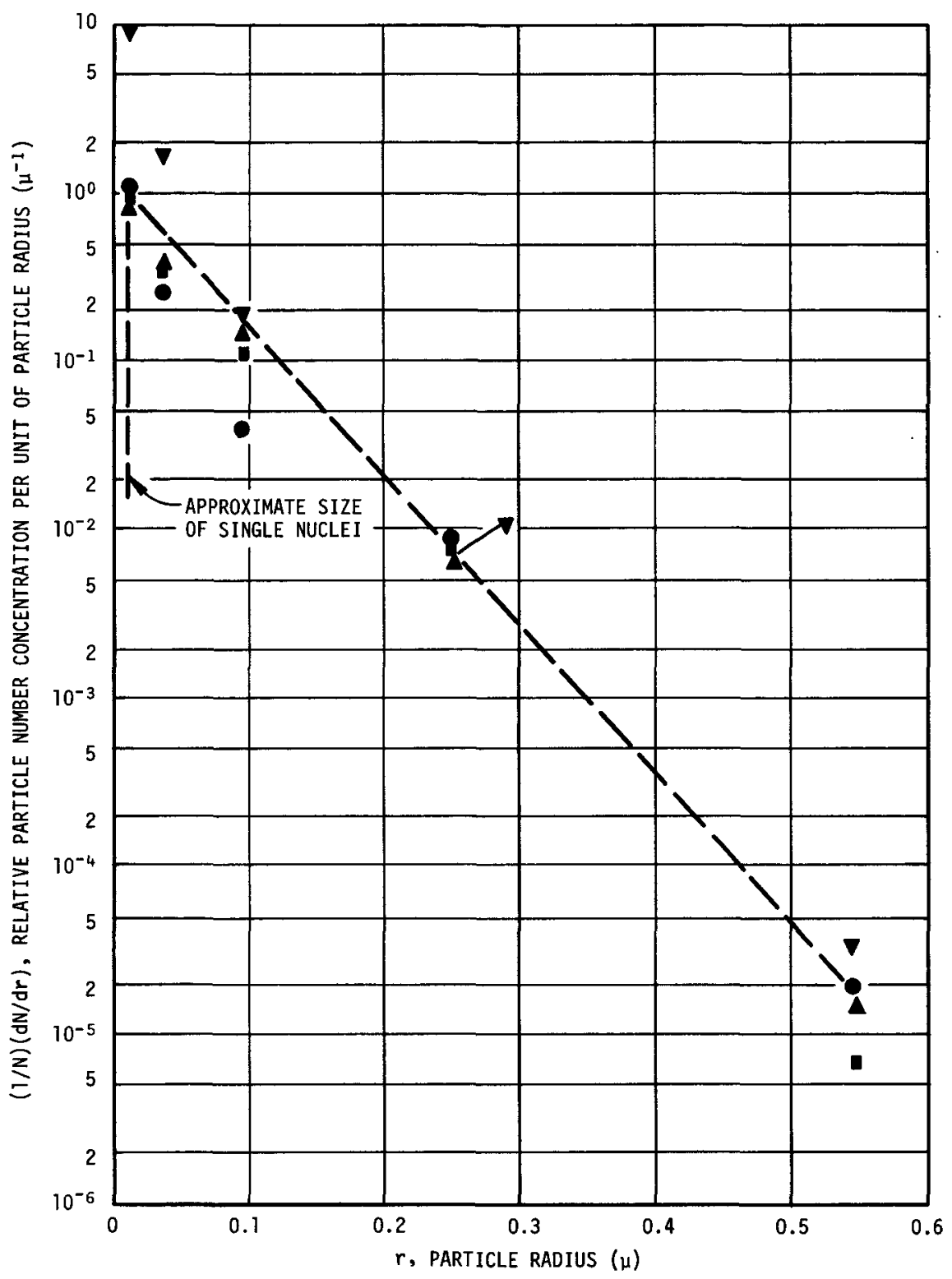

Fig. 7.2. Particle Size Distribution of Stainless Steel Oxide- $\mathrm{UO}_{2}$ Aeroso1.

is, $(1 / N)(d N / d r)$. The normalized size distribution indicates the relative number of particles in each size range. The data points on Fig. 7.2 are from low-pressure impactor measurements. ${ }^{2}$ These data indicate that most of the particles are about $0.01 \mu$ in radius or smaller. Previous electronmicroscopic studies showed that these elctric-arc-generated oxide particles are actually agglomerates of approximately spherical nuclei and that 
the nuclei are of the order of $0.01 \mu$ in radius. ${ }^{1}$ Since the smallest particles among the agglomerates must be single nuclei, it follows that the minimum particle is about $0.01 \mu$ in radius. The test aerosol was thus an assortment of agglomerate particles, but a large fraction of the total number of particles was single nuclei ( $20.01-\mu$ radius) or agglomerates of only a few nuclei.

One additional filter-medium sample labeled MSA-1/27/71 was tested. The filter penetration versus filter face velocity data are given in Fig. 7.3, along with the previous results and the theoretical values. ${ }^{3}$ As may be seen in Fig. 7.3 new data generally follow the trends established by the previous results.

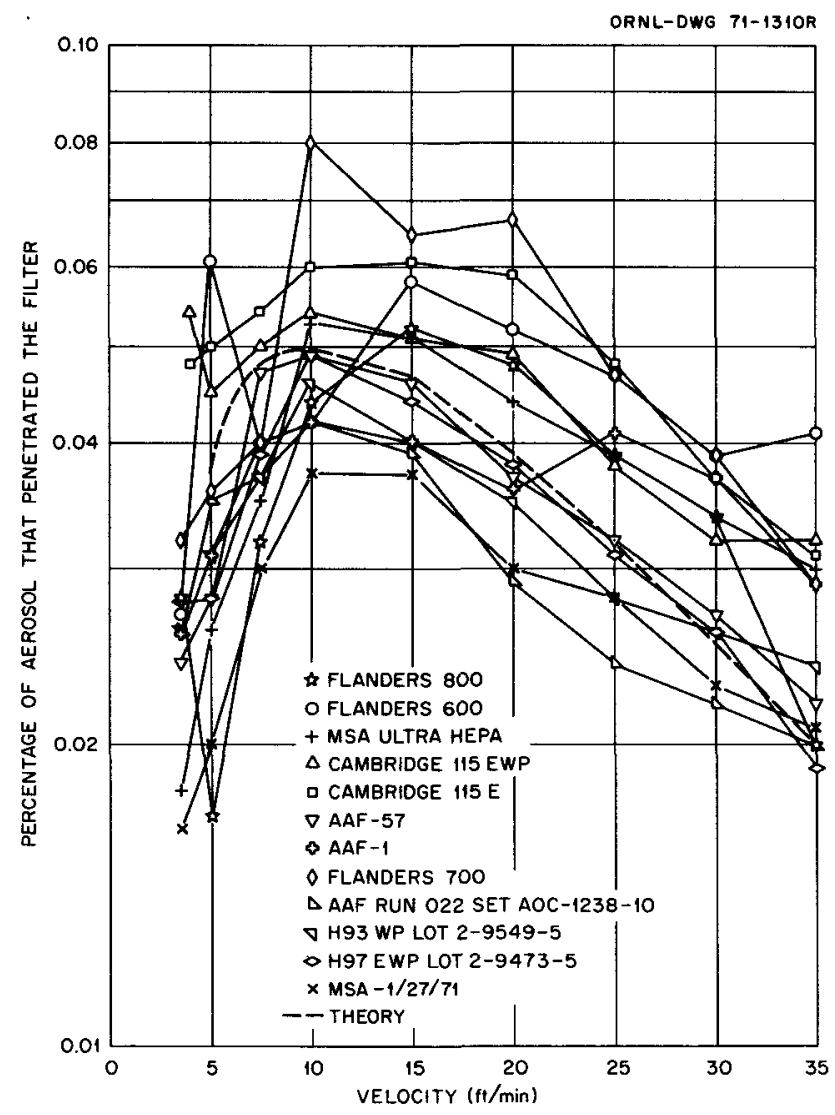

Fig. 7.3. Filter Penetration by Stainless Steel- $\mathrm{UO}_{2}$ Aerosol as a Function of Filter Face Velocity. 


\section{References}

1. R. J. Davis, J. Truitt, J. S. Gill, and R. E. Adams, Removal of Radioactive Aerosols on High Efficiency Fibrous Filter Media, USAEC Report ORNL-4524, Oak Ridge National Laboratory, June 1970.

2. G. W. Parker and H. Buchholz, Size Classification of Submicron Particles by a Low-Pressure Cascade Impactor, USAEC Report ORNL-4226, Oak Ridge National Laboratory, June 1968.

3. J. Truitt, Effect of Velocity on Filtration Efficiency of Absolute Filter Media for Stainless Steel Oxide-UO ${ }_{2}$ Aeroso1, pp. 119-121, ORNL Nuclear Safety Research and Development Program Bimonthly Report for January-February 1971, USAEC Report ORNL-TM-3342, Oak Ridge National Laboratory, 1971

\subsection{SEISMICITY AND SEISMIC RESISTANCE OF NUCLEAR POWER PLANTS}

(AEC Activity 04019101 1)

J. Foster G. D. Whitman

The program of seismic research is concerned with supplying data that will contribute to a more precise definition of earthquake conditions that must be considered in assessment of a site, establishing the suitability of sites for reactors, and improvement and verification of methods used in the design of nuclear power plants to withstand safely the effects of earthquakes. The principal activities during this reporting period were soils studies and analysis of data from blast-induced response testing of the experimental gas-cooled reactor plant and site.

An ORNL subcontract providing for a second year of work on the measurement of the dynamic properties of soils by Shannon and Wilson-Agbabian Jacobsen Associates (SW-AJA) was prepared, cleared through the AEC-ORO contracts office, and submitted to SW-AJA for signature. Expenditures under this renewed subcontract through the balance of FY-1971 will be limited to conform with existing FY-1971 funding.

In consonance with recently expressed AEC-DRDT desires relating to nuclear safety work, money from industry was sought successfully to fund, 
in part, some of the seismic research work for which midyear funding was requested. A midyear request was submitted for funds with which to carry out field tests to relate the ground-motion characteristics associated with underground chemical explosions to the burning rate of the explosive material, depth, charge weight, and delay time for sequenced charges. The money was not granted, but efforts by UCLA, where the field tests would be performed, succeeded in obtaining half of the funds required for the support of this work from industry. AEC-DRDT was notified of this development and requested to furnish the balance of the funds for these tests, the results of which are important to further strong-motion testing with chemical-explosive excitation.

Work continued on the analysis of the data obtained during the dynamic tests at the EGCR during the summer of 1970. This work is being performed by UCLA under a subcontract with the AEC that expires at the end of FY-1971.

Arrangements were made to conduct further forced-vibration tests on the San Onofre Nuclear Generating Station of Southern California Edison Company. ORNL personnel will work as part of the test team. These tests were originally scheduled to be performed during a shutdown of the plant in March 1971, but the shutdown was delayed and the tests will be performed when it is rescheduled.

A revised version of the proposed AEC seismic research program plan was prepared by ORNL following discussions with AEC-DRDT personnel earlier this year. The revised plan was submitted for review and approval or comment by AEC-DRDT. 


\section{NUCLEAR SAFETY INFORMATION}

\subsection{NUCLEAR SAFETY INFORMATION CENTER}

(AEC Activity 04607001 1)

J. R. Buchanan Wm. B. Cottrell

The Nuclear Safety Information Center was established in 1963 by the USAEC Division of Reactor Development and Technology to collect, evaluate, and disseminate nuclear safety information to governmental agencies, research and educational institutions, and the nuclear industry. The Center's basic computer file now contains references on over 52,800 documents.

\section{Computer Programming and Processing}

In order to optimize the direct-access storage space for NSIC accessions (from 2496 to 1970 characters per document) the reference master files are being revised to reflect the new format and to accommodate teleprocessing requirements in an improved manner. Phase I of the file optimization was completed. In addition to saving approximately $30 \%$ of the previously required direct-access space, the improvement in performance is also significant.

Programming was completed to provide "over-striking" of titles in the indexed bibliographies. This in effect causes the titles to stand out because of the much darker print. Efforts are under way to provide this same capability in the author and keyword indexes. Other changes were made in the bibliography program so that accessions can be arranged 
in a hierarchical manner in reports such as "Safety-Related Occurrences in Nuclear Facilities."

The IBM-2260s were inoperable from April 5 through April 15 because of a broken plate and connection in an IBM cable connector between the IBM-2848 controller and Bell Telephone Data Set. IBM and Bell service personnel worked together eight days in diagnosing and locating the problem. While the CRTs were inoperable, some NSIC input was fed to the computer through two IBM-2740 terminals.

\section{SDI and PPIF Programs}

During this period 47 new participants were added to the SDI (Selective Dissemination of Information) program; there are now 1921 users who receive biweekly copies of new material of interest to them. Fifty-nine SDI profiles were revised.

There were no additions to the PPIF (Program and Project Information File) this period; however, two profiles were revised.

\section{Bibliographies and State-of-the-Art Reports}

The reports "Nuclear Reactor Siting Practice and Its Relationship to Population," ORNL-NSIC-66, "Calculation of Doses Due to Accidentally Released Plutonium from an LMFBR," ORNL-NSIC-74, and "Safety-Reliability of Reactor Systems," ORNL-NSIC-83, are undergoing revision.

\section{Summary of Information Activities}

During the report period, the following requests were received and answered by NSIC personnel:

\begin{tabular}{lr} 
Accessions added to computer file & 1884 \\
Technical inquiries (letter or telephone) & 144 \\
$\begin{array}{l}\text { Specific NSIC reports and other nontechnical } \\
\text { inquiries }\end{array}$ & 211 \\
\hline $\begin{array}{l}\text { Aditions to NSIC reports distribution } \\
\text { Visits for consultation or use of reference } \\
\text { material }\end{array}$ & 3
\end{tabular}


Additions to SDI program

Additions to PPIF program
47

0

\subsection{TECHNICAL PROGRESS REVIEW NUCLEAR SAFETY}

(AEC Activity 140201 )

J. P. Blakely Wm. B. Cottre11

Nuclear Safety is a Technical Progress Review that is prepared and edited at ORNL on a bimonthly schedule under AEC-DTI contract. The MarchApril 1971 issue (Vo1. 12, No. 2, 112 pages, distributed Apri1 2, 1971) contained articles by seven authors from outside ORNL and six autrors from ORNL, including five on the Nuclear Safety/NSIC staff. The lead article was one by F. A. Gifford, Jr. (National Oceanic and Atmospheric Adminis.tration) in which the author reviewed the IAEA-USAEC Symposium on Envircnmental Aspects of Nuclear Power (New York City, August 1970). The principal topics considered were nuclear power as an energy source, standards for the control of effluents, effluent control and monitoring, considerations affecting steam power station site selection, and benefit versus risk assessment. A summary statement by H. J. Dunster, UKAEA Health and Safety Branch, emphasized that the symposium had presented enough material to convince anyone that nuclear power generation results in less environmental degradation than fossil-fueled power generation. He stated that, although safety judgements require more quantification, we already know enough to exclude unexpected adverse effects. He welcomed the current focus of attention on the environment, believing that the symposium had clearly demonstrated that everyone can have enough clean power.

oiver articles dealt with fast reactor safety (a UKAEA report com pilec by the Safeguards Division of the Authority's Health and Safety Branch and reviewed by N. C. Rasmussen, MIT), restricted release of plutonium (by D. C. Hunt, Dow-Rocky Flats), fission-product detection systems in HTGRs (by C. D. Baumann, ORNL), the eleventh AEC air-cleaning conference (by D. W. Moeller, Harvard University), predicting "sea-breeze fumigation" from tall stacks at coastal locations (by G. F. Collins, The Research 
Corporation of New England), meteorological effects of the heat and moisture produced by man (by S. R. Hanna and S. D. Swisher, NOAA), the fuelmelting incident at the Fermi reactor on October 5, 1966 (by R. L. Scott, Jr., ORNL), a report on the 1970 ANS conference on power-reactor systems and components (also by R. L. Scott, Jr., ORNL), and the regular currentevents features by staff members W. R. Casto, A. W. Savolainen, H. B. Whetse1, and J. P. Blakely.

Makeup on the May-June 1971 issue (Vol. 12, No. 3) was completed and sent to the printer in April for distribution in May.

External reviews for Vol. 12, No. 4 (July-August 1971) and Vol. 12, No. 5 (Sept.-Oct. 1971) are proceeding simultaneously so that $12(5)$ can be printed early for surface shipment to Geneva in July. Vol. 12, No. 5 is the special issue that is being structured especially for the Geneva IV audience; domestic and Geneva distribution will both be made in September. Vol. 12, No. 4 will be sent to the printer after the beginning of FY-72 for distribution in late July.

Draft articles for Vol. 12, No. 6, Nov.-Dec. 1971, are being received and started through in-house review.

The Jan.-Feb. 1972 and March-April 1972 issues are in various stages of outline and article invitation. 